

2169

a) $(-)^{3}$ 
Lome Corveru.

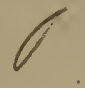

Sarmitales. peace. 


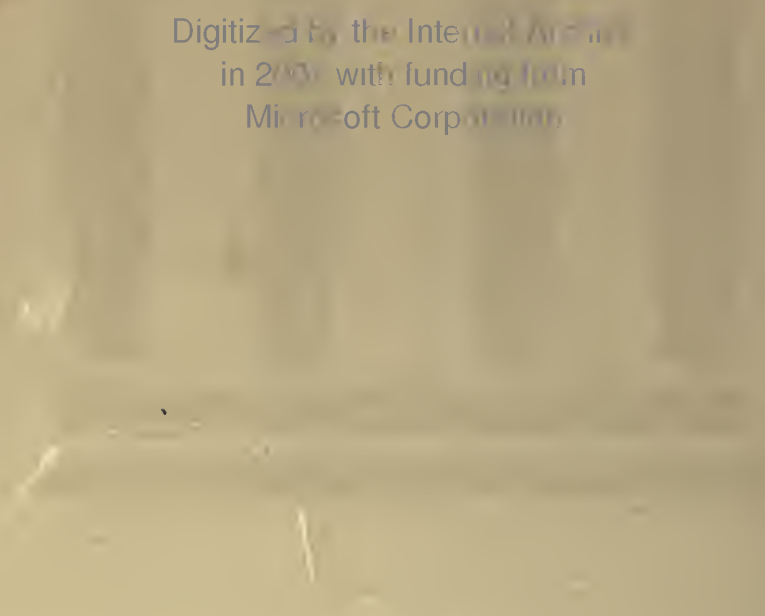

http://www.archive.org/details/elementsofagricu00wariiala 


\title{
THE
}

\section{ELEMENTS OF AGRICULTURE:}

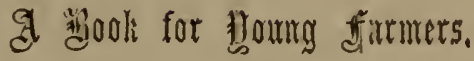

\author{
BY \\ GEO. E. WARING, Jr., \\ AUTHOR OF "DRATSLY gOR PROFT AND DRAINING FOR HRALTH," \\ FORMERLY AARICULTURAL RNGIYEER OF TILE CENTRAL \\ PARK IN NEW YORK.
}

The effort to extend the dominion of man over natnre is the most bealthy and most noble of all ambitlons.-BAcoN.

SECOND AND REVISED EDITION.

NEW YORK :

THE TRIBUNE ASSOCIATION, 154 NASSAU STREET.

1868. 
Entered according to Act of Congress, In the year 1868 , by

Gl:O. E. WARING, JR.,

In the Clerk's Onice of the District Cuurt of the Cinited States for the Southern District of New York.

The Neiv York Printing Company,

$8 \mathrm{r}, 8_{3}$, and $8_{5}$ Certre Sirect,

New Yokk. 


\section{CONTENTS.}

\section{Section first.}

'TIIF: PI, A N'T.

CHAPTER I.

Introduction

CHAPTER II.

The Atmosphere and its Carbon.................. 14

CILAPTER III.

Hydrogen and Oxygen ........................ 21

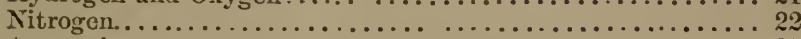

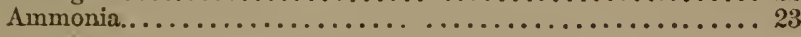

CHAPTER IV.

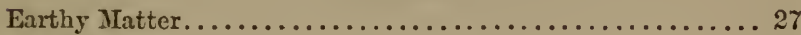

Alkalies........................................... 28

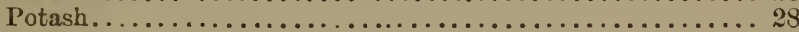

Soda............................................ 29

Lime. ......................................... 29

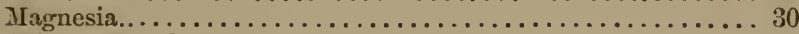

Acids-Phosphoric Acid........................... 30

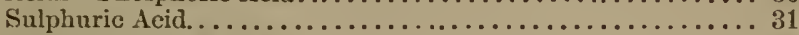

Silicic Acid, or Silica................................. 32

Ncutrals-Chlorine................................. 33

Oxide of Iron $\ldots \ldots \ldots \ldots \ldots \ldots \ldots \ldots \ldots \ldots \ldots \ldots \ldots \ldots \ldots \ldots \ldots, 33$

CHAPTER V.

Growth

CHAPTER VI.

Starch, Woody-Fibre, Gluten, etc................. 39

Animals.................................... 42

CHAPTER VII.

Location of the Different Parts, and Variations in the Ashes of Plants.

CHAPTER VIII.

Recapitulation. 


\section{Section second.}

\section{THF SOXI. \\ CIIAPTER I.}

Formation and Character of the Soil $\ldots \ldots \ldots \ldots \ldots \ldots \ldots .57$

Geology ................................ 61

CHAPTER II.

Uses of Atmospherie Matter....................6 66

CHAPTER III.

Uses of Earthy Matter....................... 72

Subsoil.................................. 74

Improvement.............................

\section{Section Thito.}

\section{$M \wedge N U \mathrm{~N}$ I $S$. \\ CHAPTER I.}

Character and Varieties of Manures.

CHAPTER II.

Animal Excrement........................... 84

Dirrestion and its Products............................ 85

CILAPTER III.

Waste of Manure.............................. 88

Evaporation................................ 88

Leaching.................................. 93

CHAPTER IV.

Absorbents.............................. 95

Charcoal................................. 95

Muek and its Treatment..................... 97

Lime and Salt Mixture........................ 99

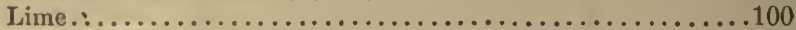

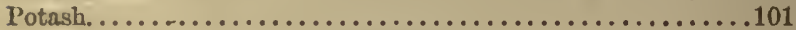

CHAPTER V.

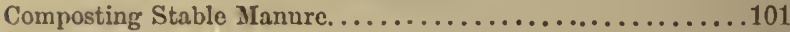

Shelter.......................................... 102

The Floor......................................... 103

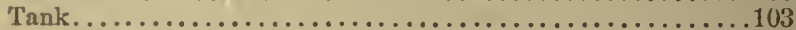

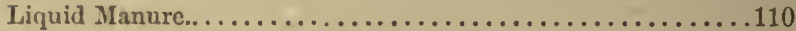

CIIAPTER VI.

Different kinds of Animal lixcrement.....................110

Stable Manure.......................................111

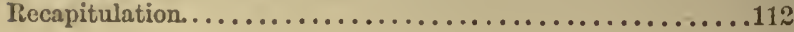


Night Soil

Poultry-house Manure...........................

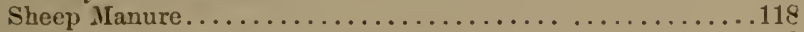

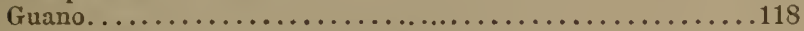

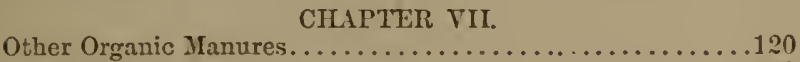

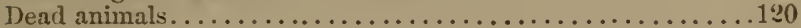

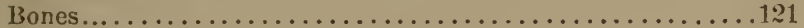

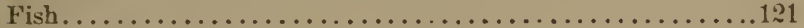

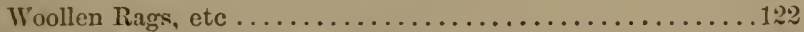

Organic Maumres of Vegetable Origin. ................. 12:3

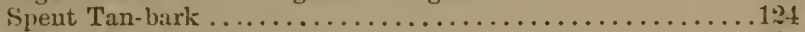

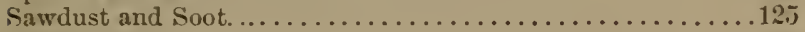

Green Crops..................................

Absorption of Moisture........................

Distribution of Manures......................... 120

\section{CIIAPTER VIII.}

Mrineral Manures................................

\section{CHAPTER IX.}

Deficiencics of Soils, Means of Restoration, etc..........135

Alkalics_Potiks . . . . . . . . . . . . . . . . . . . . . . . 1:36

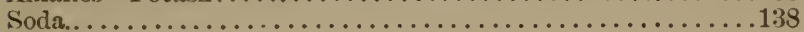

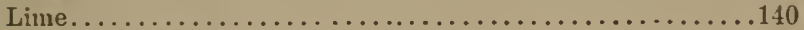

Plaster of Paris................................

Chloride of Lime...................................

Magnesia.....................................

$\Lambda$ cids - Sulphuric Acid. . . . . . . . . . . . . . . . . 148

Phosphoric Acid..............................

Bones ......................................

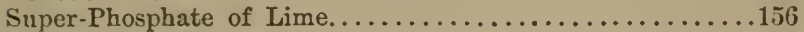

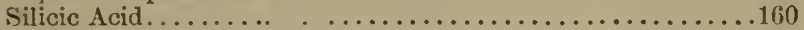

Neutrals-Chlorine ............................

Oxide of Iron ......................................

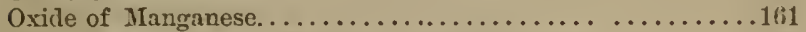

Various other Earthy MIanures-Leached Ashes...........162

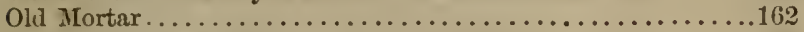

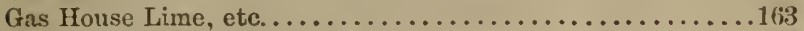

Soapers' Ley and Bleachers' Ley....................164

Irrigation. . . . . . . . . . . . . . . . . . . . . . . . 164

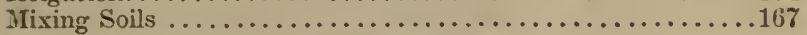

CHAPTER X.

Atmospheric Fertilizers........................169

Ammonia.....................................

Carbonic Acid.............................

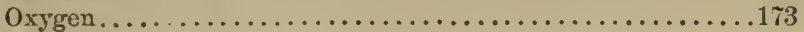

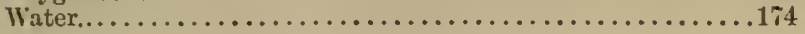




\section{Gretiou fourth.}

\section{MECIIANICAI, CUIIIVATION.}

CHAPTER I.

The Mechanical Character of Soils. .181

CHAPTER II.

Under-Draining............................... 182

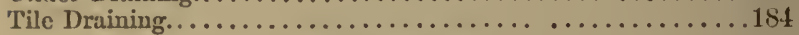

CHAPTER III.

Advantages of Under-Draining.................... 187

CHAPTER IV.

Sur joil Plowing..........................200

CHAPTER V.

Plowing and other Proeesses for Pulverizing the Soil.......206

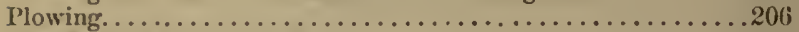

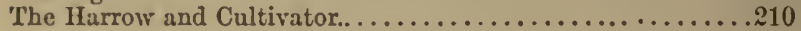

CHAPTER VI.

Rolling, Mulching, Weeding, ctc..................211

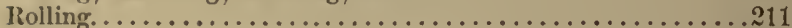

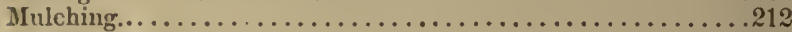

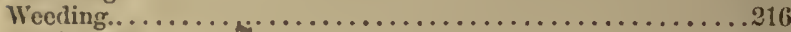

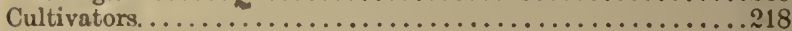

Improved Horse-Hoe. . . . . . . . . . . . . . . . . . 219

Impoved horse

Section fiftl).

ANAITSIS.

CHAPTER I.

Analysis...

CHAPIER $\mathrm{I}$.

CILAPTER II.

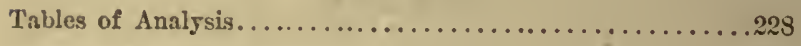

Time Practical farmer....................245)

Explanation of Terds..................... 253 
TıE first edition of this book was written in 1853 , when the writer was full of the enthusiasm that comes with the first years of study; when a very elementary knowledge of the suljects of which it treats made the whole plan of vegetation, cultivation, and manuring seem easy and simple. In some instances, rather vague fincies were presented as sound theories; and the perplexing uneertainties which beset the path of the more thorough student were ignoredbecause unknown.

The obserration and experience of the intervening years have sadly clouded some of these fancies, and the veil which hangs about the true theories of agriculture has grown harder to penetrate, - the difficulties in the way of precise knowledge have not lessened with closer acquaintance.

Notwithstanding its faults, the book received a very cordial welcome at the hands of the public,-more because such a book was much needed, than because of its real value, and it ought, long ago, to have been rewritten.

The present edition has been carefully revised, and it is believed that its doctrines are such as the positive teachings of chemistry, and the more enlightened practice of farming, wiil justify; still, it is offered with more hesitation than was 
its predecessor, and it is only offered at all because there exists a sad deficiency in this department of our agricultural literature.

The place that it is intended to fill is occupied by no other work. It is not an agricultural chemistry, nor is it a hand-book of the processes of every-day farming; - only an attempt to translate into common language, for the use of every-day farmers, that which science has discorered and has told in its own necessarily technical terms, and which practical experience has proven to be of practical ralue.

The facts which it sets forth lie at the very ground-work of the art of farming, and they are necessary to the business education of every farmer. On the universal importance of these facts the book must depend for its success; and for their sake,-not because of its own merit,-it is confidently offered to the young farmers of America, as being worthy of their most careful study.

$$
\begin{aligned}
& \text { Ogden Furm, } \\
& \text { Neroport, R. I., } 1868 .
\end{aligned}
$$




\section{. \\ $x^{2}$} \\ Sectiov binst. \\ PANT.}

SECTIOY FIRST.

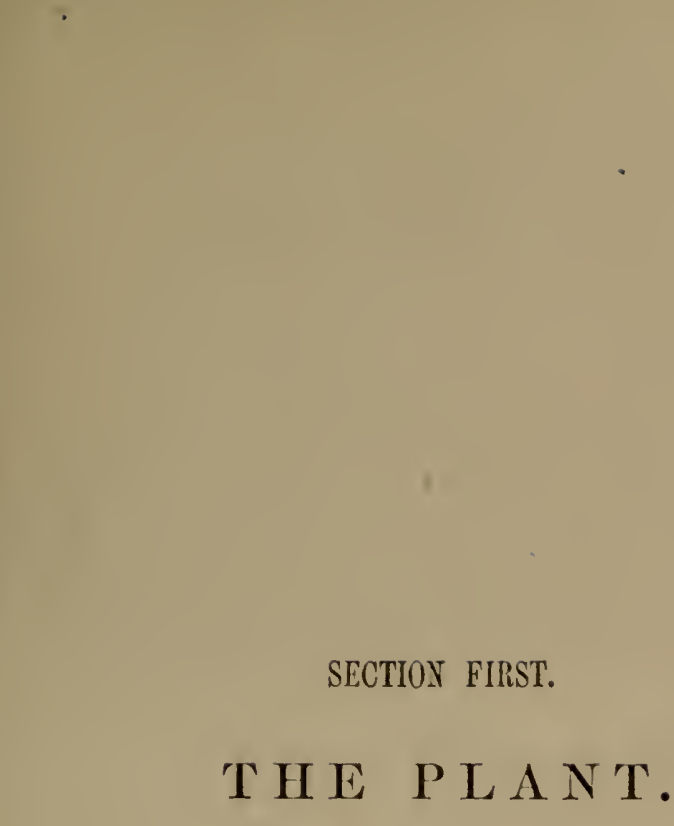

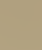

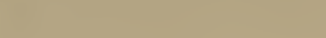

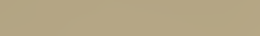

.

(n)

(n)

(n) 



\section{SECTION FIRST. \\ T II E P L A N T. \\ CHAPTER I.}

I N T RO D U C T I ON.

Tine object of eultivating the soil is to raise from it a erop of plants. In order to cultivate with economy, we nust raise the largest possible quantity with the least expense, and without permanent injury to the soil.

Before this ean be done we must study the character of plants, and learn their exact composition. They are not created by a mysterious power, they are merely made up of matters already in existence. They take up water containing food and other matter's, and discharge from their roots, or their leaves, or deposit within their pores, those substances that are not required for their growth. It is necessary for ns to know what kind of matter is required as food for the plant, and whence it is to be obtained; this we can learn only through snch means as shall separate the elements of which plants are composed; 
in other words, we must take them apart, and exanine the different pieces of which they are made up.

If we burn any regetable substance it disappears, except a small quantity of eartly matter, which constitutes the ashes. In this way we make the first division between the two distinet classes of the constituents of plants. One portion escapes into the atmosphere, and the other remains as a disorganized earthy substance.

That part which burns away during combustion we will call atmospheric matter, because it was derived by the plant from the air; the ashes which remain we will call earthy matter, because they were derived from the soil. The atmospheric matter has become air, and it was originally obtained from air. The earthy matter has become earth, and was ol)tained from the soil.

This is the first step toward a knowledge of agricultural chemistry. The next will be to examine each of these two different classes of matter, that we may learn precisely of what they consist. Then we must inquire where these substances are found, how they are taken up by the plant, and how we can best supply such as nature, unaided, does not always furnish. This knowledge does not require that farmers become chemists. All that is required is, that they should know enough of chemistry to understand, so far as the present state of knowledge makes it possible, the nature of the materials of which their crops are composed, and how those materials are to be used to the best advantage. 
The elements of this knowledge may be easily acquired, and should be possessed by every person, old or young, whether actually engaged in the cultiration of the soil or not. All are dependent on regetable productions, not only for food, but for every confort and convenience of life. It is the object of this book to teach young farmers the tirst prineiples of agriculture: and while it does not contain all that is absolutely necessary to an understanding of the practical operations of eultivation, its teachings are such as the writer found, in his early studies, to be most necessary as a groundrork for future study and thought and most useful in practice.

We will first examine the atmospheric part of plants, or that which is driven away during combustion or burning. This matter, though apparently lost, is only changed in form.

It consists of one solid substanee, carbon (or charcoal), and three gases, oxygen, hydrogen and nitrogen. These four kinds of matter constitute nearly the whole of most plants, the ashes forming sometimes less than one part in one hundred of their dry weight.

When wood is burned in a elose ressel, or otherwise proteeted from the air, its earbon beeomes charcoal. All plants contain this substance, it forming usually about one-half of their dry weight. The remainder of their atmospherie part consists of the three gases named above. By the word gas, we mean aeriform. Oxygen, hydrogen and nitrogen, when pure, always exist in the form of air. Oxygen has 
the power of miting with many substances, forming compounds which are different from either of their constituents alone. Thus: oxygen unites with iron and forms oxide of iron or iron-mest, which does not resemble the grey metallic iron nor the gas oxygen; oxygen unites with carbon and forms carbonic acid, which is an invisible gas, but not at all like pure oxygen; oxygen combines with hydrogen and forms water. All water, ice, steam, etc., are composed of these two gases. We know this becanso we can artificially decompose, or separate, all water, and obtain as a result simply oxygen and hydrogen, or we can combine these two gases and thus form pure water ; oxygen combines with nitrogen and forms nitric acid. These chemical changes and combinations take place only under certain eiremmstances, which, so fur as they affect our subject, will be considered in the following pages.

$\Lambda$ s the atmospherie elements of plants are obtained from matters existing in the atmosphere which surrounds our globe, we will examine its constitution.

\section{CHAPTER II.}

THE ATMOSPHERE AND TTS CARBON.

A tmospieric air is composed of oxygen and nitrogen. Their proportions are, one part of oxygen to four parts of nitrogen. Oxygen is the active agent in the combustion, decay, and decomposition of organized 
bodies (those which have possessed animal or vegetable life, that is, organic matter), and others,-also, in the breathing of animals. Experiments liave proved that if the atmosphere consisted of pure oxygen every thing would be speedily destroyed, as the processes of combustion and decay would be greatly quickened, and animals would be so stimulated that they would soon die. One use of the nitrogen in the air is to dilute the oxygen, and thus reduce the intensity of its effect.

Besides these two great elements, the atmosphere contains certain impurities which are of great importance to regetable growth; these are, carbonic acid, voater, ammonia, etc.

\section{CARBONIC ACID.}

Carbonic acid is, in all probability, the only source of the carbon of plants, and consequently supplies more material to regetation than any other single sort of food. It is a gas, and is not, under natural circumstances, perceptible to our senses. It constitutes about $\frac{1}{2500}$ of the atmosphere, and is found in combination with many substances in nature. Marble, limestone and chalk, are carbonate of lime, or carbonic acid and lime in combination; and carbonate of magnesia is a componnd of carbonic acid and magnesia. This gas exists in combination with many other mineral substances, and it is contained in all water not recently boiled. Its supply, though small, is sufticient for the purposes of vegetation. It enters 
the plant in two ways-through the roots in the water which goes to form the sap, and at the leaves, which absorb it from the air in the form of gas. The leaf of the plant seems to have three oftices: absorbing carbonic acid from the atmosphere-assisting in the eliemical preparation of the sap-and evaporating its water. If we examine leaves with a microscope we shall find that some have as many as 170,000 openings, or months, in a square inch; others lave a much less number. Probably the pores on the under side of the leaf generally absorb the carbonic acid. This absorptive power is illustrated when we apply the lower side of a eabbage leaf to a wound, as it draws strongly - the other side of the leaf has not an equal effect. Young green shoots and spronts doubtless have the power of absorbing and decomposing earbonic acid.

The roots of plants, by their absorbent surfaces, or through the spongioles at the ends of their roots, absorb from the soil water, which contains carbonic acid and other substances required for their nutrition. Ilow large a proportion of the carbonic acid is absorbed in this manner is not definitely known. It probably depends on varions cireumstances, but is, no donbt, always important.

Carbonic acid, it will be recollected, consists of carbon and oxygen, while it supplies only carbon to the plant. It is therefore necessary that it be divided, or decomposed, and that the earbon be retained while the oxygen is sent off again into the atmosphere, to perform again its oftice of uniting with carbon. This 
decoraposition takes place in the green parts of plants and obly under the influence of daylight. It is not necessary that the sun shine directly on the leaf or green shoot, but this causes a more rapid decomposition of carbonic acid, and consequently we find that plants which are well exposed to the sun's rays make the most rapid growth.

The fact that light is essential to regetation explains the conditions of different latitudes, which, so far as the assimilation of carbon is concerned, are much the same. At the Equator the days are but about twelre hours long. Still, as the growth of plants is extended over nearly or quite the whole year, the duration of daylight is sufficient for the requirements of a luxuriant vegetation. At the Poles, on the contrary, the summer is but two or three months long; liere, however, it is daylight all summer, and plants from continual growth derelop themselves in that short time.

It will be recollected that carbonic acid constitutes but about $\frac{1}{2500}$ of the air, yet, although about onehalf of all the regetable matter in the world is derived from this source, as well as all of the carbon required by the growth of plants, its proportion in the atmosphere is constantly abont the same. In order that we may understand this, it becomes necessary for us to consider the means by which it is formed. In the act of burning, carbon wites with oxygen, and always when bodies containing carbon are burnt with the presence of atmospheric air, the oxygen of that air unites with the carbon, and forms 
carbonic acid. The same oecurs when bodies containing carbon decay, as this is simply a slower burning and produces the same results. in the breathing of animals the carbon of the blood combines with the oxygen of the air drawn into the lungs, and their breath, when thrown out, always contains carbonic acid. From this we see that the reproduction of this gas is the direct effect of the destruction of all organized bodies, whether by fire, decay, or eonsumption by animals.

Furnaces are its wholesale manufactories. Every cottage fire is continually producing a new supply, and the blue smoke issuing from the cottage-chimney, contains materials for making food for the cottager's tables and new faggots for his firc. The wick of every burning lamp draws up the carbon of the oil to be made into carbonic acid in the flame. All matters in process of combustion, decay, fernentation, or putrefaction, are returning to the atmosphere those constituents, which they obtained from it. Every living animal, even to the smallest insect, by respiration, spends its life in the production of this material, so necessary to the growth of plants, and at death gives up its body in part for such formation by decay.

Thus we see that there is a continual ehange from the carbon of plants to air, and from air back to plants, or through them to animals. As each dollar in gold that is receired into a country permanently increases its amount of circulating medium, and each dollar sent out permanently decreases it mntil re- 
turned, so the carbonic acid sent into the atmosphere by burning, decay, or respiration, becornes a permanent stock of enstantly changeable material, until it shall be locked up for a time, as in a house which may last for centuries, or in an oak tree which may stand for thousands of years. Still, when these decay, the carbon which they contain must be again resolved into carbonic acid.

The coal-beds of Pennsylvania are mines of carbon once abstracted fiom the atmosphere by plants. In these coal-beds there are found varions forms of organized matter. These existed as living things before the great floods, and it is the theory of some geolugists that at the breaking away of the barriers of the immense lakes, of which our present lakes were inerely the deep holes in their heds, they were washed away and deposited in masses so great as to take fire from their chemical changes. It is by many supposed that this fire acting thronghont the entire mass (without the presence of air to supply oxygen except on the surface) cansed it to become melted carbon, and to flow around those bodies which still retain their shapes, clianging them to coal without destroying their structures. This coal, so long as it retains its present form, is lost to the regetable kingrdom, and each ton that is burned, by being clianged into carbonic acid, adds to the ability of the atmosphere to support regetation.

Thus we see that, in the provisions of nature, carbon, the grand basis, on which all organized matter is founded, is nerer permanent in any of its forms. 
Oxygen is the carrier which enables it to change its condition. For instance, let us suppose that we have a certain quantity of charcoal; this is nearly pure carbon. We ignite it, and it unites with the oxygen of the air, becomes carbonic acid, and floats away into the atmosphere. The wind carries it through a forest, and the leares of the trees with their millions of mouths drink it in. By the assistance of light it is decomposed, the oxygen is sent off to make more carbonic acid, and the carbon is retained to form a part of the tree. So long as that tree exists in the form of rood, the earbon will remain maltered, but when the wood deeays, or is burned, it inmediately takes the form of carbonic acid, and mingles with the atmosphere ready to be again taken up by plants, and liave its earbon deposited in the form of regetable matter.

The blood of animals contains carbon derived from their food. This unites with the oxygen of the air drawn into the lungs and forms carbonic acid. Without this process, animals conld not live. Thus, while by the natural operation of breathing, they make carbonic acid for the uses of the vegetable world, plants, in taking up carbon, throw off' oxygen to keep up the life of animals. There is perhaps no way in which we can better illustrate the changes of form in carbon than by describing a simple experiment.

Take a glass tube filled with oxygen gas, and put in it a lump of charcoal, cork the ends of the tube tightly, and pass through the eorks the wires of an electrieal battery. By passing a stream of 
electrical fluid over the charcoal it may be ignited, when it will burn with great brillianey. In burning it unites with the oxygen forming carbonic acicl, and disappears. It is no more lost, howerer, than is the carbon of wood which is burned in a stove; although invisible, it is still in the tube, and may be detected by careful weighing. A more satisfactory proof of its presence may lie obtained by decomposing the earbonic acid by drawing the wires a short distance apart, and giving a spark of electricity. This immediately separates the oxygen from the carbon, which forms a dense black smoke in the tube. By pushing the corks together we may obtain a "rafer of chareoal of the same weight as the piece introduced. In this experiment we have changed carbon from its solid form to an invisible gas and back again to a solid, thus fully representing the continual changes of this substance in the destruction of organic matter and the growth of plants.

\section{CHAPTER III.}

HYDROGEN, OXYGEN AND YITROGEN.

\section{IIYDROGEN AND OXYGEN.}

LET us now consider the three gases, hydrogen, oxygen, and nitrogen, which constitute the remainder of the atmospheric part of plants. 
Water is composed of lydrogen and oxygen, and, if analyzed, yields simply these two gases. Plants perform such analysis, and in this way are able to obtain a sufficient supply of these materials, as their sap is eomposed chiefly of water. Whenever regetable inatter is destroyed by burning, deeay, or otherwise, its hydrogen and oxygen unite and form water, which usually eseapes in the form of an invisible vapor. 'The atinosphere of eourse eontains greater or less quantities of watery vapor arising from this enuse and from the eraporation of liquid water. This rapor condenses, forming rains, etc.

Iydrogen and oxygen are never taken into consideration in manuring lands, as they are so readily obtained from the water constituting the sap of the plant, and consequently they need not oecupy our attention in this book.

\section{NITROGEN.}

Nitrogen, the only remaining atmospheric constituent of vegretable matter, is for many reasons worthy of close attention.

1. It is necessary to the growth and perfection of ${ }^{\circ}$ all cultivated plants.

2. It is necessary to the formation of all animal substances.

3. It is often deficient in the soil.

4. It is liable to be easily lost fiom manures.

Atlough about four-fifths of atmospheric air are pure nitrogen, it is almost certain that plants get no 
nutriment directly from this source. It is all obtained from some of its compounds, chicfly from the one called ammonia. Nitric acid is also a source from which plants may obtain nitrogen, though, to the furmer, it is of less importance than ammonia.

\section{AMIONIA.}

Ammonia is composed of nitrogen and hydrogen. It lias a pungent smell and is familiarly known as hartshorn. The sime odor is often perceptible around stables and other places where animal matter is decomposing. All animal muscle, certain parts of plants and other organized substances, consist of componnds containing nitrogen. When these compounds undergo combnstion, or are in any manner decomposed, the nitrogren which they contain unites with hydrogen, and forms ammonia. In consequence of this the atmosphere always contains more or less of this gas, arising from the decay and combustion which are continually going on all over the world.

This ammonia in the atmosphere and that which is contained in the soil (derived from the decomposition of organic matters within it) is the eapital stock to which all plants, not artificially manured, must look for their supply of nitrogen. As they take up ammonia chiefly if not entirely through their roots, we must discover some means by which it may be conveyed from the atmosphere to the soil.

Water may be male to absorb many times its 
bulk of this gas, and water with which it comes in contact will immediately take it up. Spirits of hartshorn is merely water through which ammonia has been passed mutil it is saturated.* This power of water has a direct application to agriculture, because the water constituting rains, dews, etc., absorbs the anmonia which the decomposition of nitrogenous matter liad sent into the atmosphere, and we find that all rain, snow, and dew, contain ammonia. This fact may be chemically proved in rarious ways, and is perceptible in the common eperations of nature. Every person must have noticed that when a summer's shower falls on the plants in a flower garden, they commence their growth with fresh vigor, while the blossoms become larger and more richly colored. This effect cannot be produced by watering with spring water, unless it be previously mixed with ammonia, in which case the result will be the same.

Although ammonia is a gas and pervades the atmosphere, few, if any, plants can take it up, as they do earbonic acid, through their leaves. It must all entel through the roots in solution in the water which goes to form the sap. Although the amount received from the atmosphere is of great importance, there are few cases where artificial applications are not beneficial. The value of farm-yard and other animal manures, depends largely on the ammonia which they yield on decomposition. This

* By gaturated, we mean that it contains all that it is capable of holding. 
subject, also the means for retaining in the soil the ammoniacal parts of fertilizing matters, will be fully considered in the section on manures.

After ammonia las entered the plant it may be decomposed, its hydrogen separated from it, and its nitrogen retained to answer the purposes of growth. The changes which nitrogen undergoes, from plants to animals, or, by decomposition, to the form of anmonia in the atmosphere, are as varied as those of carbon and the constituents of water. The same little atom of nitrogen may one year form a part of a plant, and the next become a constituent of an animal, or, with the decomposed dead animal, may form a part of the soil. If the animal should fall into the sea it may beeome food for fishes, and onr atom of nitrogen may form a part of a fish. That fish may be eaten by a larger one, or at death may become food for the whale, through the marine insect on which it feeds. After the abstraction of the oil from the whale, the nitrogen may, by the putrefaction of his remains, be united to hydrogen, form ammonia, and escape into the atmospliere. From here it may be brought to the soil by rains, and enter into the composition of a plant, from which, could its parts speak as it grows in our garden, it conld tell us a wonderful tale of travels, and assure $u s$ that, after wandering about in all sorts of places, it had returned to us, the same little atom of nitrogen which we had owned twenty years before, and which for thousands of years had been continually going through its changes. 
Liebig says: "All the nitrogen of plants and of animals is derived from the air. Every fireplace where coals are burned, the numerous furnaces and chimneys of the manufacturing towns and distriets, of locomotive engines and steanboats, all the smelting furmaces of the iron-works-all these are so many forms of distillatory apparatus which enrich the atmosphere with tlre nitrogenized food of a vegetable world, belonging to a period long past.

"We can form some idea of the quantities of ammonia thus poured into the atmosphere, if we consider that in numerous gas-works many tons of ammoniaeal salts are annually obtained from the coals distilled for gas." *

The same is true of any of the atmospheric or earthy constituents of plants. They are performing their natural offices, or are lying in the earth, or floating in the atmosphere, ready to be lent to any of their legitimate uses, sure again to be returned to their starting point.

Thus no atom of matter is ever lost. It may change its place, but it remains for ever as a part of the eapital of nature.

* Journal of the Royal Agricultural Society, vol. xvii., p. 289. 


\section{CHAPTER IV.}

EARTHY MATTER.

WE will now examine the ashes left after burning vegetable substances. This is earthy matter; and it is obtained from the soil. Atmospheric matter, although forming so large a part of the plant, we have seen to consist of four different substances. The earthy portion, on the contrary, although forming so small a part, consists of no less than nine or ten different kinds of matter. These we will consider in order. In their relations to agriculture they may be divided into three classes-alkalies, acids, and noutrals.*

Alkalies and acids are of opposite properties, and when brought together they unite and neutralize each other, forming compounds which are neither alkaline nor acid in their character. Thus, carbonic acid (a gas) unites with lime-a burning, caustic substance-and forms marble, which is a hard, tasteless stone. Alkalies and acids are characterized by their tendency to unite with each other, and the compounds thus formed have many and various properties, so that the characters of the constituents give no indication of the character of the compound. For instance, lime causes the gases of animal manure

* This classification is not strictly scientific, but it is one which the learner will find it well to adopt. These bodies are called neutrals because they have a less decided alkaline or acid character thon the other. 
to escape, while sulphate of lime (a compound of sulphuric acid and lime) produces an opposite effect, and prevents their escape.

The substances coming under the signifieation of nentrals, are less affeeted by the laws of combination, still they do combine with other substances, and some of the resultant compounds are of great importance to agriculture.

\section{ALKALIES.}

The alkalies which are found in the ashes of plants are four in number; they are potash, soda, lime, and magnesia.

\section{PUTASII.}

When we pour water over wood ashes it dissolves the potash which they contain, and carries it away in solution. This solution is called ley, and if it be boiled to dryness it leares a solid substance which is ehiefly pure potash. Potash left exposed to the air absorbs earbonic acid and becomes carbonate of potash or pearlash ; if another atom of carbonic acid be added, it becomes super-carbonate of potash, or salceratus. Potash has many uses in agriculture.

1. It forms a eonstituent of nearly all plants.

2. It unites with silicic acid and forms a eompound which water can dissolve and carry into the roots of plants; thus supplying them with an ingredieut which gives them much of their strength. 
3. It is a strong agent in the decomposition of regetable matter, and is thus of much importance in preparing manures.

4. It roughens the smooth round particles of sandy soils, and prevents their compacting, as they are often liable to do.

5. It is also of use in killing certain kinds of insects, and, when externally applied, in smoothing the bark of fruit trees.

The source from which this and the other earthy matters required are to be obtained, will be more fully considered in the section on mauures.

SODA.

Soda, one of the alkalies contained in the ashes of plants, is very much the same as potash in its agricultural character and uses. Soda exists very largely in nature, as it forms an important part of common salt, whether in the ocean or in those inland deposits known as rock salt. When combined with sulphuric acid it forms sulphate of soda or Glauber's salts. In combination with carbonic acid, as carbonate of soda, it forms the common washing soda of the shops.

\section{LIME.}

Lime is in many ways important in agriculture:

1. It is a constituent of plants and animals.

2. It assists in the decomposition of vegetable matter in the soil as well as of its minerals.

3. It corrects the acidity* of sour soils.

* Sourness. 
4. Combined with chlorine or sulphuric acid as chloride or sulphate of lime it is a good fixer of fertilizing gases.

In nature it exists most largely in the form of carbonate of lime; that is, as marble, limestone, and chalk-these all being of the same composition. In manufucturing eaustic (or quick) lime, the carbonate of lime is burned in a kiln; by this means the carbonic acid is driven off into the atmosphere and the lime remains in a pure or caustic state.

\section{MAGNESIA.}

Magnesia is the remaining alkali of vegetable ashes. It is well known as a medicine, both in the form of calcined magnesia, and, when mixed with sulphuric acid, as epsom salts.

Although magnesia is a necessary constituent of plants, it is not an element of which fertile soils are likely to become exhausted, and it does not receive attention in special manuring; the amount returned to the soil in farm-yard manure, and that supplied by the decay of roots, being sufficient for the growth of the most luxuriant erops.

\section{ACIDS.}

PMOSPHORIO ACID.

Phosphoric acid is a constituent of the ashes of plants which is of the greatest value to the farmer; it is composed of phosphorus and oxygen. Being an 
acid, this substance has the power of combining with any of the alkalies. Its most important compound is formed with lime.

Phosphate of lime forms abont 65 per cent. of the dry weight of the bones of all animals, and it is all derived from the soil through the inedium of plants. As plants are intended as food for animals, nature has provided that they shall not attain their perfection without taking up a supply of phosphate of lime as well as of their other earthy ingredients; consequently, there are many soils which will not produce good crops, simply because they are deficient in phosphate of lime. It is one of the most important ingredients of manures, and its value is dependent on certain conditions which will be hereafter explained.

Another use of phosphoric acid in the plant is to supply it with the small amount of phosphorus, which seems to be required in the formation of the seed.

\section{SULPHURIC ACID.}

Sulphuric acid is important to vegetation, and its addition to the soil often renders it more fertile. It is composed of sulphur and oxygen, and is made for manufacturing purposes, by burning sulphur. With lime it forms sulphate of lime, which is gypsum or "plaster." In this form it is often found in nature, and is most extensively used in agriculture. The methods for supplying sulphuric acid will be described hereafter. It gives to the plant a small 
portion of sulphur, which is necessary to the formation of some of its parts.

\section{SILICIC ACID, OR SILICA.}

This is common sand. In its pure state it eannot be dissolved and plants can make no use of it. It unites with the alkalies and forms compounds, such as silicate of potash, silicate of soda, etc., which are soluble in water, and therefore available to plants. If we roughen a corn stalk with sand-paper we may sharpen a knife upon it. This is owing to the liard particles of silica which its outer parts contain. Window glass is silicate of potash, rendered insoluble by additions of arsenic and litharge.

Liebig tells us that there was discorered, between Manheim and Heidelberg in Germany, a mass of melted glass where a liay-stack had been struck by lightning. They supposed it to be a meteor, but chemieal analysis showed that it was only the compound of silicic acid and potash which served to strengthen the grass.

There is always enough silicic acid in the soil, but it is often necessary to add an alkali to render it soluble and available. When grain; etc., lodge or fall down from their own weight, it is probable that they are unable to obtain from the soil a sufficient supply of the soluble silicates to support their rapid growth. 
NEUTRALS.

\section{CIILORINE.}

Chlorine is an important ingredient of vegetable ashes. It is not found alone in nature, but is always in combination with other substances. Its most important compound is with sodium, forming chloride of sodium (or common salt). Sodium is the base of soda, and common salt is usually the cheapest source from which to obtain both soda and chlorine. Chlorine unites with lime in the formation of chloride of lime, which is much used to absorb or destroy the unpleasant odors of decaying matters, and in this character it is of use in the treatment of manures.

\section{OXIDE OF IRON.}

Oxide of iron, one of the constituents of ashes, is common iron rust. Iron itself is naturally of a greyish eolor, but when exposed to the atmosphere, it readily absorbs oxygen and forms a reddish compound. It is in this form that it usually exists in the soil, and many soils as well as the red sandstones are colored by.it. It is seldom, if ever, necessary to apply this as a manure, there being usually enough of it in the soil.

This red oxide of iron, of which we have been speaking, is called by chemists the peroxide. There is another compound which contains less oxygen than this, and is ealled the protoxide of iron, which is 
poisonous to plants. When it exists in the soil it is necessary to use such means of eultivation as sliall expose it to the atmosphere and allow it to take up more oxygen and beeome the peroxide. The black seales which fly from hot iron when struck by the blacksmith's hammer are protoxide of iron.

The peroxide of iron is a very good absorbent of ammonia, and consequently, as will be hereafter deseribed, adds to the fertility of the soil.

Oxide of Manganese, though often found in small quantities in the ashes of cultivated plants, cannot be considered indispensable.

Having now examined the materials from which the ashes of plants are formed, we are enabled to classify them in a simple manner, so that they may be recollected. They are as follows :-

ALKALIES.

Potash.

Soda.

Lime.

Magnesia.
ACIDs.

Sulphurie acid. Chlorine. Phosphoric " Silicic
Oxide of Iron.

" Manganese.

\section{CHAPTER V.}

G ROW T H.

HaVING examined the materials of which plants are made, it becomes necessary to discover how they are . 
put together in the process of growth. Let us therefore suppose a young wheat-plant, for instance, to be in condition to commence independent growth.

It consists of roots which are located in the soil; leaves which are spread in the air, and a stem which connects the roots and leares. This stem contains sap ressels, which may be regarded, for the sake of simplicity, as tubes extending from the ends of the roots to the surfaces of the leaves, thus affording a passage for the sap, and consequently allowing the natters taken up to be distributed throughout the plant.

It is neeessary that the materials of which plants are made shonld be supplied in certain proportions, at the proper time, and in a suitable eondition. For instance, carbon conld not be taken up in large quantities by the leares, unless the roots, at the same time, were receiving from the soil those mineral matters which are necessary to growth. On the other hand, no considerable amount of earthy matter conld be appropriated by the roots unless the leaves were obtaining carbon from the air. This same rule holds true with regard to all of the eonstituents required; Nature seeming to have made it a law that if one of the important ingredients of the plant is absent, the others, though they may be present in sufficient quantities, cannot be used. Thus, if the soil is deficient in alkalies, and still has sufficient quantities of all of the other ingredients, the plant cannot take up these ingredients, because alkalies are necessary to its life. 
If a farmer wishes to make a cart he prepares his wood and iron, gets them all in the proper condition, and then can very readily put them together. But if he has all of the wood necessary and no iron, he cannot make his cart, becanse bolts, nails and screws are required, and their place eannot be supplied by boards. This serves to illustrate the fact that in raising plants we must give them everything that they require, or they will not grow at all.

In the case of our young plant the following operations are going on at about the same time.

The leaves are absorbing carbonic acid from the atmosphere, and the roots are drinking in water from the soil.

The manner in which food is taken up by roots, may be illustrated by the following experiment: Take a tumbler, filled entirely full with water ; tie over it a bladder, and on the bladder sprinkle a little salt. The bladder becomes moist thronghout its entire thickness, and transmits enough moisture to the salt to dissolve it gradually, and as fast as it is dissolved, it passes through the bladder into the water inside of the tumbler. In a long enough time the water can be made, in this way, to dissolve as much salt as though it had been stirred into it without the intervention of the bladder. If we keep the salt soaking wet, as it lies on the outside of the bladder, it will pass through much more rapidly, but if we do not wet it by a direet application of water, enough water will reach it throngh the membrane to allow it to pass into the tumbler, as above described. 
The roots of plants contain sap, which is separated from the plant-food in the soil, by a thin film of matter, which constitutes its cell-walls. So long as the water of the sap has the capacity to dissolve more mineral matter than it already contains, it will take it through the cell-walls, as the salt is taken through the bladder. If the plant-food ontside of the roots is in a moist condition, it will be taken up more rapidly than if too dry. The moisture of the soil itself, containing mineral matter in solution, passes through the cell-walls to supply the place of that which has been evaporated at the leaves, the matters in solution passing through with the water itself.

In short, there is a constant tendency to supply the deficiency of water in the root, and to keep it constantly charged with as much as it can dissolve of the plant-food, firom which it is separated only by its membranous cell-walls.

Under the influence of daylight, the carbonic acid is decomposed; its oxygen returned to the atmosphere, and its carbon retained in the plant.

The water taken in by the roots circulates through the sap vessels of the plant, and is drawn up towards the leaves, where it is evaporated. This water contains the nitrogen and earthy food required by the plant and some carbonie acid, while the water itself consists of hydrogen and oxygen.

'Thus we see that the plant obtains its food in the following manner:- 
Carbon.-In the form of carbonic acid from the atmosphere, and from that contained in the sap, the oxygen being returned to the air.

$\left.\begin{array}{c}\text { OXYGEN } \\ \& \\ \text { HrDRogen. }\end{array}\right\} \begin{gathered}\text { From the elements of the water con- } \\ \text { stituting the sap. }\end{gathered}$

Nitrogen.-From the soil (chiefly in form of ammonia). It is carried into the plant through the roots in solution in water. Eartiry from the soil, and only in solution in Matrer. $\}$ water.

Many of the ehemical changes which take place in the interior of the plant are well, and some but imperfectly understood, but they require too much knowledge of chemistry to be easily comprehended by the young learner, and it is not absolutely essential that they should be understood by the scholar who is merely learning the elements of the science.

It is sufficient to say that the food taken up by the plant undergoes such changes as are required for its growth; as in animals, where the food taken into the stomach is digested, and is afterward formed into bone, muscle, fat, hair, etc., so in the plant the nutritive portions of the sap are resolved into wood, bark, grain, or other necessary parts.

The results of these changes are of the greatest importance in agrieulture, and no person ought to be called a thoroughly practical farmer who does not understand them. 


\section{CHAPTER VI.}

STARCH, WOODY - FIBRE, GLUTEN, ETC.

WE have hitherto examined the raw material of plants. That is, we have looked at each one of the elements separately, and considered its use in vegetable growth.

We will now consider another division of plants. We know that they consist of various substances, such as wood, gum, starch, oil, etc., and on examination we shall discover that these substances are composed of the various atmospheric and earthy ingredients described in the preceding chapters. They are made up almost entirely of atmospheric matter, but their ashy parts, though very small, are (as we shall presently see) of great importance.

These compounds may be divided into two classes.

The first class are composed of carbon, hydrogen, and oxygen.

The second class contain the same substances and nitrogen.

The first class (those compounds not containing nitrogen) comprise the wood, starch, gum, sugar, and fatty matter, which constitute the greater part of all plants, also the acids which are found in sour fruits, etc. Various as are all of these things in their characters, they are entirely composed of the same ingredients (carbon, hydrogen, and oxygen), and usually combined in about the same proportion. There may 
be a slight difference in the composition of their ashes, but the organie part derived from the atmosphere is mueh the same in erery ease, so much so, that they can often be artificially changed from one to the other.

As an instance of this, it may be stated that at the Fair of the American Institute, in 1834, Prof. Mapes exhibited samples of excellent sugar made from the juice of the corn-stalk, from stareh, from linen, and from woody fibre.

In the plant, during its growth, they are eonstantly changing. At one time they assume a form in which they eannot be dissolved by water, and remain fixed in their places.

At another, the chemical influenees on whieh growth depends, ehange them to a soluble form, and they are carried, by the cireulation of the sap, to other parts of the organism, where they may be again deposited in other insoluble forms. For example, the turnip devotes the first season of its growth to storing up in its root a large amount of starch and peetie aeid; in the seeond season, these substances beeome soluble, are taken up by the circulation aud again deposited in the form of woody fibre, starch, ete., in the stems, leave's, seed-vessels, etc., above the ground. If a turnip root be planted in the spring, in moist eotton, from which it can get no food, it will simply, by the transformation of its own substance, form stems, leaves, flowers and seed.

Those products of regetation which eontain nitrogen, are of the greatest importance to the farmer, being the ones from which animal musele is made. 
They consist, as will be recollected, of carbon, lyydrogen, oxygen and nitrogen, or of all of the atmospheric elements of plants. They are all of much the same character, though each kind of plant has its peculiar form of this substance, which is known under the general name of protein.

The protein of wheat is called gluten-that of Indian corn is zein-tliat of beans and peas is legumin. In other plants the protein substances are vegetable albumen, casein, etc.

Gluten absorbs large quantities of water, which causes it to swell to a great size, and become full of holes. Flour which contains much gluten, makes light, porous bread, and is preferred by bakers, because it absorbs so large an amount of water.

The nitrogenous substances are necessary to animal and regetable life, and none of our cultirated plants will attain maturity, (complete their growth,) unless allowed the materials required for forming them. To furnish this condition is the chief object of nitrogen given to plants as manure. If no nitrogen could be? obtained these substances could not be formed, and the plant must cease to grow.

When, on the contrary, ammonia is given to the soil, (by rains or otherwise, it furnishes nitrogen, while the carbonic acid and water yield the other constituents of protein, and a healthy growth continues, provided that the soil contains the earthy matters required in the formation of the ash, in a condition to be taken up by the roots.

The wisdom of this provision is evident when we 
recolleet that the nitrogenous substances are neeessary to the formation of muscle in animals, for if plants were allowed to complete their growth without a supply of nitrogen, our grain and hay might not be sufficiently well supplied with it to keep our oxen and horses in working condition, while under the existing law, plants must be of nearly a uniform quality, (in this respect,) and if a field is short of nitrogen, its crop will not be large, and of a very poor quality, but the soil will produce good plants as long as the nitrogen lasts, and then the growth must cease.*

\section{ANDLALS.}

That this principle may be clearly understood, it may be well to explain more fully the application of the different constituents of plants in feeding animals.

Animals are composed (like plants) of atmospheric and earthy matter, and every thing necessary to build them up exists in plants. It is one of the offices of the vegetable world to prepare the gases in the atmosphere and the minerals in the earth for the uses of animal life, and, to effect this, plants put these gases and minerals together in the form of the various compound substances which we have just described.

In animals the compounds containing no nitrogen comprise the fatty substances, parts of the blood, etc., while the protein compounds, or those which

* It is of course assumed that the soil is fertile in other respects. 
do contain nitrogen, form the muscle, a part of the bones, the hair, and other portions of the body.

Animals contain a larger proportion of earthy matter than plants do. Bones contain a large quantity of phosphate of lime, and we find other earthy compounds performing important offices in the system.

In order that animals may be perfectly developed, they must, of course, receive as food all of the materials required to form their bodies. They cannot live if fed entirely on one ingredient. Thus, if starch alone be eaten by the animal, he might become fat, but his strength would soon fail, beeanse his food contains nothing to keep up the vigor of his muscles. If on the contrary the food of an animal consisted entirely of gluten, he might be very strong from a superior developinent of muscle, but would not become fat. Hence we see, that in order to keep up the proper proportion of both fat and muscle in our animals, (or in ourselves,) the food must be such as contains a proper proportion of both classes of regetable produets.

It is for this reason that grain, wheat for instance, is so good for food. It contains both classes of proximates, and furnishes material for the formation of both fat and muscle. The value of flour depends very much on the manner in which it is manufactured. This will be explained hereafter.

Apart from the relations between the organic parts of plants, and those of animals, there exists an important relation between their askes or their earthy 
parts; and food, in order to satisfy the demands of animal life, must eontain the mineral matter required for the purposes of that life. Take bones for instance. If phosphate of lime is not always supplied in sufficient quantities in the food, animals are prevented from forming healthy bones. This is particnlarly to be noticed in teetl. Where food is deficient of phosphate of lime, we see poor teeth as a result. Some physicians have supposed that one of the causes of consumption is the deficiency of phosphate of lime in food.

The first class of vegetable constituents (starch, sugar, gum, etc.) perform an important office in the animal economy aside from their use in making fat. They constitute the fuel which supplies the animal's fire, and gives him his heat. The lungs are the delicate stoves, which supply the whole body with heat. But let us explain this matter more fully. If wood, starch, gum, or sugar, be burned in a stove, they produce heat. These substances consist, as will be recollected, of carbon, hydrogen, and oxygen, and when they are destroyed in any way, (provided they be exposed to the atmosphere, the hydrogen and oxygen unite and form water, and the carbon unites with the oxygen of the air and forms carbonic acid, as was explained in a preceding chapter. This process is always accompanied by the production of heat, and the intensity of this heat depends on the time oceupied in its produetion. In slow decay, the chemical changes take place so slowly that the heat, being conducted away as soon as formed, is not per- 
ceptible to our senses. In combustion (or burning) the same clianges take place with much greater rapidity, and the same amount of heat, being concentrated, or brought out in a far slorter time, it becomes intense, and therefore apparent. In the lungs and blood-ressels of animals the same law holds true. The blood contains matters belonging to this carbonaceous class, and they undergo, during its eirculation, the changes which have been described under the head of combustion and decay. Their hydrogen and oxygen unite, and form the moisture of the breath, while their carbon is combined with the oxygen of the air drawn into the lungs, and is thrown out as carbonic acid. The same consequence-heat-results in this, as in the other cases, and this heat is produced with sufficient rapidity for the necessities of the animal. When he exercises violently, his blood circulates with increased rapidity, thus carrying carbon more rapidly to the lungs. The breath also becomes quicker, thus supplying increased quantities of oxygen. In this way the decomposition becomes more rapid, and the animal is heated in proportion.

Thus we see that food has another function besides that of forming animal matter, namely to supply heat. When the food does not contain a sufficient. quantity of starch, sugar, etc., to answer the demands of the system, the animal's own fat is carried to the lungs, and there used in the production of heat. This important fact will be referred to again. 


\section{CHAPTER VII.}

LOCATION OF THE DIFFERENT PARTS, AND VARIATIONS IN THE ASHES OF PLANTS.

LET us now examine plants with a view to learning the location of the various parts.

The stem or trunk of the plant or tree consists very largely of woody fibre; this also forms a large portion of the other parts except the seeds, and, in some instances, the roots. The roots of the potato contain large quantities of starch. Other roots, such as the carrot and turnip, contain pectic acid,* a nntritions substance resembling stareh.

It is in the seed, however, that the more nutritive portions of most plants exist, and here they maintain certain relative positions which it is well to understand, and which can be best explained by reference to the following figures, as described by Prof. Johnston:-

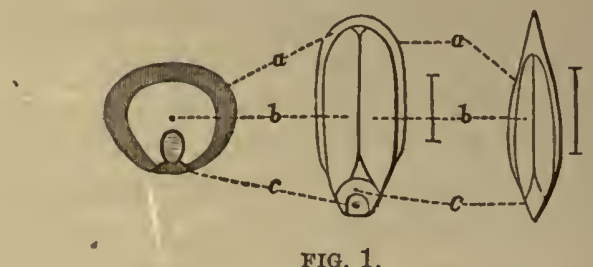

FIG. 1.

"Thus $a$ shows the position of the oil in the outer

* This pectic acid gelatinizes food in the stomach, and thus renders it more digestible. 
part of the seed-it exists in minute drops, inclosed in six-sided cells, which consist chiefly of gluten; $b$, the position and comparative quantity of the starch, which in the heart of the seed is mixed with only a small proportion of gluten; $c$, the germ or chit, which contains much ghuten." *

The location of the earthy parts of plants is of much interest, and shows the adaptation of each part to its particular use. Take a wheat plant, for instance-the stalk, the leaf, and the grain, show in their ashes, important difference of composition. The stalk or straw contains three or four times as large a proportion of ash as the grain, and a no less remarkable difference of composition may be noticed in the ashes of the two parts. In that of the straw, we find a large proportion of silicic acid and scarcely any phosphoric acid, while in that of the grain there is scarcely a trace of silicic acid, although phosphoric acid constitutes about one half of the entire weight. The leaves contain a considerable quantity of lime.

This may at first seem an unimportant matter, but on examination we shall see the use of it. The straw is intended to support the grain and leares, and to convey the sap from the roots to the upper portions of the plant. To perform these oftices, strength is required, and this is given by the silicic acid, and the woody fibre which forms so large a proportion of the stalk. The silicic acid is combined with an alkali, and constitutes the glassy coating of the straw. While the plant is young, this coating is

* See Johnston's Elements, page 41. 
hardly apparent, but as it grows older, as the grain becomes heavier, (verging towards ripeness,) the silicious coating of the stalk assumes a more prominent character, and gives to the straw sufficient strength to support the golden head. The straw is not the most important part of the plant as food, and it contains but little phosphoric acid, which is so necessary to animals.

The grain, on the contrary, is especially intended as food, and therefore must contain a large proportion of phosphoric acid-this being, as we have already learned, necessary to the formation of bonewhile, as it has little necessity for strength, and as silicic acid is not needed by animals, this ingredient exists in the grain only in a very small proportion. It may be well to obscrve that the phosphoric acid of grain exists most largely in the hard portions near the shell, or bran. This is one of the reasons why Graham (or unbolted) flour is more wholesome than fine flour. It contains all of the nutritive materials which render the grain valuable as food, while flour which is very finely bolted* contains only a small part, of the outer portions of the grain (where the phosphoric acid, protein and fatty matters exist most largely). The starchy matter in the interior of the grain, which is the least capable of giving strength to the animal, is carefully separated, and used as food for man, while the better portions, not being ground so finely, are rejected. This one thing alone may be sufficient to account for the fact, that the lives of

* Sifted through a fine cloth called a bolting cloth. 
men have become shorter and less blessed with health and strength, than they were in the good old days when a stone mortar and a coarse sieve made a respectable flour mill.

Another important fact concerning the ashes of plants is the difference of their composition in different plants. Thus, the most prominent ingredient in the ash of the potato is potash; of wheat and other grains, phosphoric acid; of meadow hay, silicic acid; of clover, lime; of beans, potash, etc. In grain, potash (or soda), etc., are among the important ingredients.

These differences are of great importance to the practical farmer, as by understanding what, kind of plants uses the most of one ingredient, and what kind requires another in large proportion, he can regulate his crops so as to prevent his soil from being exhansted more in one ingredient than in the others, and can also manure his land with reference to the crop which he intends to grow. The tables of analyses in the fifth section will point out these differences approximately. The composition of ashes varies a little, but not enongh to affect the value of the tables for the uses of the farmer.

\section{CHAPTER VIII.}

RECA PIT ULA TION.

$W_{E}$ have now learned as much about the plant as is required for our immediate uses, and we will care- 
fully reconsider the various points with a view to fixing them permanently in the mind.

Plants are composed of atmospheric and earthy matter.

A tmospheric matter is that which burns away in the fire. Earthy matter is the ash left after burning.

\& The organic matter of plants consists of three gases, oxygen, hydrogen aud nitrogen, and one solid substance, carbon (or charcoal). The mineral parts consist of potash, soda, lime, magnesia, sulphuric acid, phosphoric acid, silicic acid, chlorine, oxide of iron, and oxide of manganese.

Plants obtain their atmospheric food as follows :Oxygen and hydrogen from water; nitrogen from some compound containing nitrogen (chiefly from ammonia); and carbon from the atmosphere, where it exists as carbonic acid-a gas.

6 They obtain their earthy food from the soil. The water which supplies oxygen and hydrogen to plants is readily obtained without the assistance of manures.

7. Ammonia is obtained from the atmosphere, by being absorbed by rain and carried into the soil, and it enters plants through their roots. It may be artificially supplied in the form of animal manure with advantage.

8 Carbonic acid is absorbed from the atmosphere by leaves, and decomposed in the green parts of plants under the influence of daylight; the carbon is retained, and the oxygen is returned, to the atmosphere. 
When plants are destroyed by decay, or burning, their organic constituents pass away as water, ammonia, carbonic acid, etc., ready again to be taken up by other plants.

The earthy matters in the soil can enter the plant only with the aid of water. Potash, soda, lime, and magnesia, are soluble in their pure forms. Magnesia is injurions when present in too large quantities.

Sulphuric acid is often used as a manure, and is usually most available in the form of sulphate of lime or plaster. It is also valuable in its pure form to prevent the escape of ammonia from composts.

Phosphoric acid is highly important, from its frequent deficiency in worn-out soils. It is most readily taken up by plants under certain conditions which will be described in the section on manures.

I Silicic acid is common sand, and must be united to an alkali before it can be used by the plant, because it is insoluble except when so united.

14 Chlorine is a constituent of common salt (chloride of sodium), and from this source may be obtained in sufficient quantities for manurial purposes.

$1 / 5$ Oxide of iron is iron rust. There are two oxides of iron, the peroxide (red) and the protoxide (black). The former is advantageous in the soil, and the latter poisons plants.

Oxide of manganese is often absent from the ashes of our cultivated plants.

The food of plants, both organic and earthy, must 
be present at the time when it is required and in sufficient quantity. In the plant, this food undergoes such chemical changes as are necessary to growth.

The compound substances contained in plants are of two classes, those not containing nitrogen, and those which do contain it.

The first elass constitute nearly the whole plant.

The second class, although small in quantity, are of the greatest importance to the farmer, as from them all animal muscle is made.

2 Animals, like plants, are composed of both atmospheric and earthy matter, and their bodies are obtained directly or indirectly from plants.

22 The first class of compounds in animals comprise the fat, and like tissues.

2 i The second class form the muscle, hair, gelatine of the bones, ete.

24 In order that they may be perfectly developed, food, and in the proportions required by their natures.

$25^{-} \quad$ They require phosphate of lime and other mineral food which exists in plants.

Aside from their use in the formation of fat, substances of the first class are employed in the lungs and blood-vessels as fuel to keep up animal heat, which is produced (as in fire and decay) by their decomposition.

When the food is insufficient for the purposes of heat, the animal's own fat is decomposed, and carried to the lungs as fuel. 
The stems, roots, branches, ete., of most plants consist principally of woody fibre.

Their seeds, and sometimes their roots, contain considerable quantities of starch.

The nitrogenized substances and the oils of most plants exist most largely in the seeds, therefore seeds are the most nutritious food for animals, beeanse they contain the largest proportion of digestible matter.

The location of the different compounds in the plant, as well as of its mineral parts, shows a remarkable reference to the purposes of growth, and to the wants of the animal world, as is noticed in the difference between the constrnction of the straw and that of the kernel of wheat.

2 The reason why the fine flour now made is not so healthfully nutritious as that which contained more of the coarse portions, is that it is robbed of a large proportion of protein and phosphate of lime, while it contains an undue amount of stareh, which is available only to form fat, and to supply fuel to the lungs.

Different plants have ashes of different composition. Thus-one may take from the soil large quantities of potash, another of phosphoric acid, and another of lime. By understanding these differences, we shall be able so to regnlate our rotations that the soil may not be called on to supply more of one ingredient than of another, and thus it may be kept in balance.

The facts contained in this chapter are the alpha- 
bet of agriculture, and the learner should become perfectly familiar with them, before proceeding further.

To enter more fully and more scientifically upon the consideration of the various properties of these substances, and of their relations to each other, would, no doubt, be in better accordance with the demands of accurate knowledge; but the foregoing is belicved to be a perfectly true, although a very simple statement of the first principles of the growth and composition of plants, and is sufficient for the first steps in agricultural study.

A clear comprehension of what is herein set forth should have the effect of stimulating a further search, in which more extended treatises will become necessary. 
THE SOIL.
SEcTior SECOXd.

SECTIOI SECOND.

\section{THE SOIL. \\ THE SOIL. \\ THE SOIL.

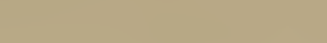

.

-

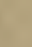

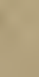

$\sqrt{2}+x^{2}$

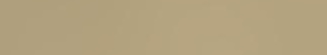

(1)

(1)

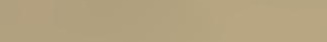

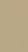

.

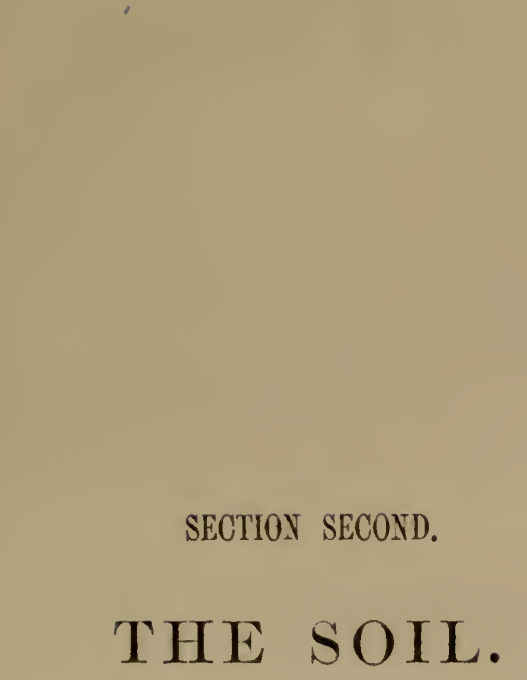

.

Con

.

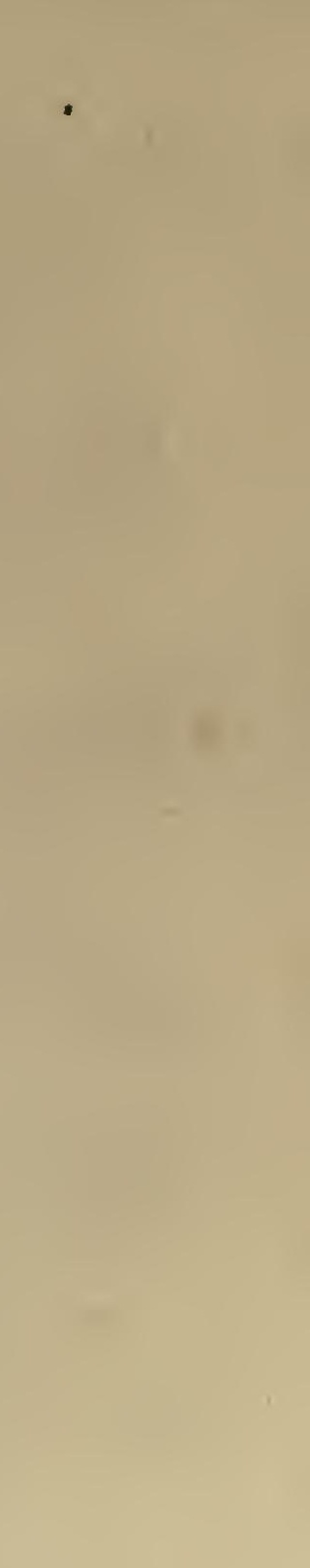





\section{SECTION SECOND.}

\section{THE SOIL.}

\section{CHAPTER I.}

FORMATION AND CHARACTER OF THE S O I L.

Is the foregoing section, we have studied the character of plants and the laws which govern their growth. We learned that one necessary condition for growth is a fertile soil, and we must examine the nature of different soils, in order that we may understand the relations between them and plants.

The soil is not to be regarded as a mysterious mass of dirt, whereon crops are produced by a mysterions process. Well ascertained scientific knowledge has proved beyond question that all soils, whether in America or Asia, whether in Maine or California, have certain fixed properties, which render them fertile or barren, and their fertility or barrenness de- pends, first of all, on the presence or absence of those minerals which constitute the ashes of regetable productions. 
- The soil is a great chemical compound, and its chemical character is ascertained (as in the case of plants) by analyzing it, or taking it apart.

We first learn that fertile soils eontain both atmosphcric and earthy matter; but, mnlike the plant, they usually possess much more of the latter than of the former.

In the plant, the atmospheric matter constitutes the most considerable portion of the whole. In the soil, on the contrary, it usually exists in very small quantities, while the earthy parts constitute nearly the whole bulk.

The atmospherie or organie part of soils consists of the same materials that constitute the atmospheric part of the plants, and is in reality decayed vegetable and animal matter. It is not necessary that this organie part of the soil should form any particular proportion of the whole, and indeed we find it varying from one and a half to fifty, and sometimes, in peaty soils, to over seventy per cent. All fertile soils contain some organic matter, althongh it seems to make but little difference in fertility, whether it be five or fifty per cent.

The earthy part of soils is derived from the crumbling of roeks. Some rocks (such as the slates in Central New York) decompose, and crumble rapidly on being exposed to the weather; while granite, nimarble, and other rocks, will last for a long time withont perceptible change. The causes of this crumbling are various, and are important to be understood by the agriculturist, as by the same process- 
es by which the soil was originally formed, he can increase its depth, or otherwise improse it. This being the case, we will in a few words explain some of the principal pulverizing agents.

1. The action of frost. When water lodges in the crerices of rocks, and freezes, it expands, and bursts the rock, on the same principle that canses it to break a pitcher in winter. This power is rery great, and by its assistance large cannon may be burst. Of course, the action of fiost is the same on a small scale as when applied to large masses of matter, and, therefore, we find that when water freezes in the pores* of rocks or stones, it separates their particles and causes them to crumble. The same rule holds true with regard to stiff clay soils. If they are ridged in autumn, and left with a rough surfice exposed to the frosts of winter, they will become much lighter and finer, and can afterwards be worked with less difficulty.

2. The action of water. Many kinds of rock become so soft on being soaked with water, that they readily crumble.

3. The chemical changes of the constituents of the rock. Many kinds of rock are affected by exposure to the atmosphere, in such a manner, that changes take place in their chemical character, and cause them to fall to pieces. The red kellis of New Jersey, (a species of sandstone,) is, when first quarried. a very hard stone, but on exposure to the influ-

* The spaces between the particles. 
ences of the atmosphere, it becomes so soft that it may be easily crushed between the thumb and finger.

Other actions, of a less simple kind, exert an influence on the stubbornness of rocks, and cuuse them to be resolved into soils.* Of coulse, the composition of the soil nust be similar to that of the rock from which it was formed; and consequently, if we know the chemical character of the rock, we ean tell whether the soil formed from it ean be brought under profitable cultivation. Thus felspar, on being pulverized, yields potash; talcose slate yields magnesia; marls yield lime, etc.

The soil formed entirely from rock, contains, of course, 110 organic matter. Still, it is capable of bearing plants of a certain class, and when these die, they are deposited in the soil, and thus form its organic portions, rendering it capable of supporting those plants which furnish food for animals. Thousands of year's must liave heen occupied in preparing the earth for habitation by man.

- As the earthy part of the soil is usually the largest, we will consider it first.

As we have stated that this portion is formed from rocks, we will examine their character, with a view to showing the different qualities of soils.

As a general rule, it may be stated that all rocks

* In very many instances the crevices and seams of rocks are permeated by roots, which, by decaying and thus induoing the growth of other roots, cause these crevices to become filled with organic matter. This, by the absorption of moisture, may expand with sufficient power to burst the rock. 
are either sandstones, limestones, or clays; or a mixture of two or more of these ingredients. Hence we find that all mineral soils are either sandy, calcareous (limey), or clayey; or cousist of a mixture of these, . in which one or another usually predominates. Thus, we speak of a sandy soil, a clay soil, etc. These distinctions (sandy, clayey, loamy, etc.) are important in considering the mechanical character of the soil, but have little reference to its chemical conditions of fertility.

By mechanical character, we mean those qualities which affect the ease of cultivation-excess or deficicncy of water, ability to withstand dronght, etc. For instance, a heary clay soil is difficult to plow, retains water after rains, and bakes quite hard during drought; while a light sandy soil is plowed with ease, often allows water to pass through immediately after rains, and becomes dry and powdery during dronght. Notwithstanding those differences in their mechanical character, both soils may be very fertile, or one more so than the other, without reference to the clay and sand which they contain, and which, to our observation, form their leading characteristics. -The same facts exist with regard to a loam, a calcareous (or limey) soil, or a regetable mould. Their mechanical texture is not necessarily an index to their fertility, nor to the manures required to enable them to furnish food to plants. It is true, that each kind of soil appears to have some general quality of fertility or barrenness which is well known to practical men, yet this is not founded on the fact that, 
the elay or the sand, or the regetable matter, enter more largely into the constitution of plants than they do when they are not present in so great quantities, - but on certain other facts which will be hereafter explained.

As the following names are used to denote the character of soils, in ordinary agricultural description, we will briefly explain their application:

A Sandy soil is, of course, one in which sand largely predominates.

Clay soil, one where clay forms a large proportion of the soil.

Loamy soil, where sand and clay are more equally mixed.

Marl eontains from five to twenty per cent. of carbonate of lime.

Calcareous soil more than twenty per cent.

Peaty soils, pf course, contain large quantities of organic matter.*

We will now take under consideration that part of the soil on which depends its ability to supply food to the plant. This portion rarely constitutes more than five or ten per cent. of the entire soil, often'much less-and it has no reference to the sand, clay, and vegetable matter's which they contain. From analyses of many fertile soils, and of others which are barren or of poorer quality, it has been ascertained that the presence of certain ingredients is necessary to fertility. This may be bet-

* These distinctions are not essential to be learned, but are often convenient. 
ter explained by the assistance of the following table:

\begin{tabular}{|c|c|c|c|}
\hline In one hundred pounds. & $\begin{array}{l}\text { Soil fertile } \\
\text { without } \\
\text { manure. }\end{array}$ & $\begin{array}{c}\text { Good } \\
\text { wheat soil. }\end{array}$ & Barren. \\
\hline $\begin{array}{l}\text { Organic matter } \\
\text { Silicic acid (sand) } \\
\text { Alumina (clay) } \\
\text { Lime } \\
\text { Magnesia } \\
\text { Oxide of iron } \\
\text { Oxide of manganese } \\
\text { Potash } \\
\text { Soda } \\
\text { Chlorine } \\
\text { Sulphuric acid } \\
\text { Phosphoric acid } \\
\text { Larbonic acid }\end{array}$ & $\begin{array}{r}9.7 \\
64.8 \\
5.7 \\
5.9 \\
.9 \\
6.1 \\
.1 \\
.2 \\
.4 \\
.2 \\
.2 \\
.4 \\
4.0 \\
1.4\end{array}$ & $\begin{array}{r}7.0 \\
74.3 \\
5.5 \\
1.4 \\
.7 \\
4.7 \\
1.7 \\
.7 \\
.1 \\
.1 \\
.1 \frac{1}{2} \\
3.6 \frac{1}{2}\end{array}$ & $\begin{array}{r}4.0 \\
77.8 \\
9.1 \\
.4 \\
.1 \\
8.1 \\
.1\end{array}$ \\
\hline & 100.0 & 100.0 & 100.0 \\
\hline
\end{tabular}

The soil represented in the first and second columns might still be fertile with less organic matter, or with a larger proportion of clay (alumina), and less sand (silicic acid). These affect its mechanical character; but, if we look down the columns, we notice that there are small quantities of lime, magnesia and the other constituents of the ashes of plants (except oxide of manganese). It is not necessary that they should be present in the soil in the exact quantity named above, but not one must be entirely absent, or greatly reduced in proportion. By referring to the third column, we see that these ingredients are not all present, and the soil is barren. Even if it were supplied with all but one or two, potash and soda for instance, it could not support a crop without the assistance of manures con- 
taining these alkalies. The reason for this must be readily seen, as we have learned that no plant can arrive at maturity without the necessary supply of materials required in the formation of the ash, and these materials can be obtained only from the soil ; consequently, when they do not exist there, it must be barren.

The earthy part of soils has two distinet oftices to perform. The elay and sand form a mass of material into which roots can penetrate, and which support plants in their position. These parts also absorb heat, air and moisture, to serve the purposes of growth, as we shall see in a futmre chapter. The minute portions of soil, which comprise the acids, alkalies and neutrals, furnish plants with their ashes, and are the most necessary to the fertility of the soil.

\section{GEOLOGY.}

The relation between the earthy parts of soils and the rocks from which it was formed, is the foundation of Agrieultural Geology. Geology may be briefly named the science of the rocks. It would not be appropriate in an elementary work, to introduce much of this study, and we will therefore simply state that the same kind of rock is of the same composition all the world over; consequently, if we find a soil in New England formed from any particnlar rock, and a soil from the same rock in Asia, their natural fertility will be the same in both localities. All rocks consist of a mixture of different kinds of minerals; and some, eonsisting chiefly of one ingredient, are of 
different degrees of hardness. Both of these qualities must affect the character of the soil, but it may be laid down as a rule that, when the rocks of two locations are exactly alike, the soils formed from them will be of the same natural fertility, and in proportion as the chemical character of rocks changes, in the same proportion will the soils differ in fertility.

In most districts the soil is formed from the rock on which it lies; but this is not always the case. Soils are often formed by deposits of matter brought by water from other localities. Thus the alluvial banks of rivers consist of matters brought from the eountry through which the rivers have passed. The river Nile, in Egypt, yearly overflows its banks, and deposits large quantities of inud brought from the uninhabited upper comntries. The prairies of the West owe their soil chicfly to deposits by water. Swamps often receive the washings of adjacent hills; and, in these cases, their soil is derived from a foreign source.

We might continue to enumerate instances of the relations between soils and the sources whence they originated, thus demonstrating more fully the importance of geology to the farmer ; but it would be beyond the scope of this work, and should be investigated by scholars more advanced than those who are studying merely the elemerts of agricultural science.

The mind, in its early application to any branch of study, should not be charged with intricate subjects. It should master well the mudiments, before investigating those matters which should follow such understanding. 
By pursuing the proper course, it is easy to learn all that is necessary to form a good foundation for a thorough aequaintance with the subject. If this foundation is laid thoronghly, the learner will regard plants and soils as old acquaintances, with whose formation and properties he is as familiar as with the construction of a building or a simple machine. A simple spear of grass will become an object of interest, forming itself into a perfect plant, with full development of roots, stems, leares, and seeds, by processes with which he feels acquainted. The soil will cease to be mere dirt; it will be viewed as a compound substance, whose composition is a matter of interest, and whose eare may become a source of intellectual pleasure. The commencement of study in any science must necessarily be wearisome to the untrained mind, but its more advanced stages amply repay the trouble of early exertions.

\section{CHAPTER II.}

\section{USES OF ATMOSPHERIC MATTER.}

It will be recollected that, in addition to its mineral portions, the soil contains atmospheric or organic matter in taried quantities. It may be fertile with but one and a half per cent. of atmospheric matter, and some peaty soils contain more than fifty per cent. or more than one-half of the whole. 
The precise amount necessary cannot be fixed at any particular proportion; probably five parts in a hundred is better than a smaller amount.

The soil obtains its atmospheric matter in two ways. First, by the decay of roots and dead plants, also of leaves, which have been brought to it by. wind, etc. Second, by the application of animal or vegetable manures.

When a crop of clover is raised, it obtains its carbon from the atmosphere; and, if it be plowed under, and allowed to decay, a portion of this carbon is deposited in the soil. Carbon constitutes nearly the whole of the dry weight of the clover, aside from the constituents of water; and when we calculate the immense quantity of hay and roots grown on an acre of soil in a single season, we shall find that the anount of earbon thus deposited is immense. If the clover be remored, and the roots only left to decay, the amount of carbon deposited would still be very great. The same is true in all eases where the crop is removed, and the roots remain to add to the organic or vegetable part of the soil. While undergoing decomposition, a portion of this matter escapes in the form of gas, and the remainder chiefly assumes the form of carbon (or chareoal), in which form it will always remain, without loss, unless driven out by fire. If a bushel of eharcoal be mixed with the soil now, it will be the same bushel of chareoal, neither more nor less, a thonsand years hence, unless some influenee is brought to bear on it aside from the growth of plants. It is true that, in the case of the 
decomposition of organic matter in the soil, eertain compounds are formed, known under the general names of humus and humic acid, which may, in a slight degree, affect the growth of plants, but their practical importance is of too doubtful a character to justify us in considering them. The application of manures, containing organic matter, snch as peat, inuck, animal manure, etc., supplies the soil with earbon on the same principle, and the decomposing matters also generate * carbonic acid gas while being decomposed. The agrienltural value of carbon in the soil depends (as we have stated), not on the fact that it enters into the composition of plants, but on certain other important offices which it performs, as follows :-

1. It makes the soil more retentive of manures.

2. It eauses it to appropriate larger quantities of the fertilizing gases of the atmosphere.

3. It gives it greater power to absorb moisture.

4. It renders it warmer.

1. Carbon (or chareoal) makes the soil retentive of manures, because it has in itself a strong power to absorb, and retain fertilizing matters. There is a simple experiment by which this power ean be shown.

Ex.-Take two barrels of pure beach sand, and mix with the sand in one barrel a few handfuls of charcoal dust, leaving that in the other pure. Pour a pailful of the brown liquor of the barn-yard through the pure sand, and it will pass out at the * Produce. 
bottom unaltered. Pour the same liquor through the barrel containing the charcoal, and only pure water will pass throngh. The reason for this is that the charcoal retains all of the impurities of the liquor, and allows only the water to pass through. Charcoal is often employed to purify water for drinking, or for mannfacturing purposes.

A rich garden-soil contains large quantities of carbonaceons matter; and if we bury in such a soil a piece of tainted meat or a fishy duek, it will, in a short time, be deprived of its odor, which will be entirely absorbed by the cliarcoal and clay in the soil.

Carbon absorbs gases, as well as the impurities of water; and, if a little charcoal be sprinkled over manure, or any other substance, emitting offensive odors, the gases escaping will be taken up by the charcoal, and the odor will be very mueh modified.

It has also the power of absorbing eartliy matters, which are contained in water. If a quantity of salt water be filtered throngh charcoal, the salt will be retained, and the water will pass through pure.

We are now able to see how earbon renders the soil retentive of manures.

1st. Manures, which resemble the brown liquor of barn-yards, have their fertilizing matters taken out, and retained by it.

2 d. The gases arising from the decomposition (rotting) of manure are absorbed by it.

$3 d$. The soluble earthy portions of manure, which might in some soils leach down with water, are 
arrested and retained at a point at which they can be taken up by the roots of plants.

2. Carbon in the soil canses it to appropriate larger quantities of the fertilizing gases of the atmosphere, on account of its power, as just named, to absorb gases.

The atmosphere contains gases, which have been produced by the breathing of animals, by the decomposition of various kinds of organic matter, which are exposed to atmospheric influenees, and by the burning of wood, coal, ete. These gases are chiefly ammonia and carbonic acid, both of which are largely absorbed by water, and eonsequently are contained in rain, snow, and dew, which, as they enter the soil, give up these gases to the carbon, and they there remain until required by plants. Even the air itself, in circulating through the soil, gives up fertilizing gases to the carbon, which it may contain.

3. Carbon gives to the soil power to absorb moisture, because it is itself one of the best absorbents in nature; and it has been proved by aceurate experiment that peaty soils absorb moisture with greater rapidity, and part with it more slowly than any others.

4. Carbon in the soil renders it warmer, because it darkens its color. Black surfaces absorb more heat than light ones, and a black coat, when worn in the sun, is warmer than one of a lighter color. By mixing carbon with the soil, we darken its color, anct render it eapable of absorbing a greater amount of heat from the sun's rays. 
It will be recollected that, when regetable matter decomposes in the soil, it produces certain gases (carbonic acid, etc.), which either escape into the atmosphere, or are retained in the soil for the use of plants. The production of these gases is always accompanied by heat, which, though scarcely perceptible to our senses, is perfectly so to the growing plant, and is of much practical importance. This will be examined more fully in speaking of manures.

Another important part of the organic matter in the soil is that which contains nitrogen. This forms but a very small portion of the soil, but it is of very great importance to regetation. As nitrogen in food is of absolute necessity to the growth of animals, so nitrogen in the soil is indispensable to the growth of cultivated plants. It is obtained by the soil in the form of ammonia (or nitric acid) from the atmosphere, or by the application of animal or regetable matter. In some cases, manures called nitrates* are used; and, in this manner, nitrogen is given to the soil.

We have now learned that the atmospheric matter in the soil performs the following offices:-

Organic matter thoroughly decomposed is chiefly carbon, and has the various effects ascribed to this substance on p. 68 .

Organic matter in process of decay produces car-

* Nitrates are compounds of nitric acid (which consists of nitrogen and oxygen), and alkaline substances. Thus nitrate of potash (saltpetre), is composed of nitric acid and potash; nitrate of soda (cubical nitre or cubic-petre), of nitric acid and soda. 
bonic acid and ammonia in the soil ; its decay also causes heat.

Organic matters containing nitrogen, such as animal substances, etc., furnish ammonia, and other nitrogenous substances to the roots of plants.

\section{CHAPTER III.}

USES OF EARTH Y M T TER.

TuE offices performed by the earthy constituents of the soil are many and important.

These, as well as the different conditions in which the bodies exist, are necessary to be carefully considered.

Those parts which constitute the larger proportion of the soil, namely the clay, sand, and limy portions, are useful for purposes which have been named in the first part of this section, while the clay has an addi. tional effect in the absorption of ammonia.

For this purpose, it is quite as effectual as charcoal ; the gases escaping from manures, as well as those existing in the atmosphere, and in rain-water, being arrested by clay as well as by charcoal.

The more minute ingredients of the soil-those which enter into the construction of plants - exist in conditions which are more or less favorable or injurious to vegetable growth. The principal condi- 
tion necessary to fertility is capacity to be dissolved, it being (so far as we have been able to ascertain) a fixed rule, as was stated in the first section, that $n$ n mineral substance can enter into the roots of a plant except it be dissolved in water.

The alkalies potash, soda, lime, and magnesia, arein nearly all of their combinations in the soil sufficiently soluble for the purposes of growth.

The acids are, as will be recollected, sulphuric, silicic, and phosphoric. These exist in the soil in combination with the alkalies, as sulphates, silicates; and phosphates, which are more or less soluble under natural circumstances. Phosphoric acid in combination with lime as phosphate of lime is but slightly soluble ; but, when it exists or has existed in the compound known as superphosphate of lime, it is inuch more soluble, and consequently enters into the composition of plants with much greater facility. This inatter will be more fully explained in the section on manures. Silicic acid exists in the soil usually in the form of sand, in which it is, as is well known, perfectly insoluble; and, before it can be used by plants, which often require it in large quantities, it must be made soluble, by combination with an alkali.

For instance, if there is a deficiency of soluble silicic acid in the soil, the application of an alkali, such as potash, which will unite with the sand, and form the silicate of potash, will give it the ability to be dissolved and carried into the roots of plants.

Chlorine in the soil is probably always in an available condition. 
Oxide of iron exists, as has been previously stated, usually in the form of the peroxide (or red oxide). Sometimes, however, it is found in the form of the protoxide (or black oxide), which is soluble and is poisonous to plants, and renders the soil unfertile. By loosening the soil in such a manner as to admit the air, and by removing stagnant water by draining, this compound takes up more oxygen, which renders it a peroxide, and makes it insoluble except in the slight degree required for plants. The oxide of manganese is probably of little consequence.

The usefulness of all of these matter's in the soil depends largely on their exposure to the action of roots and of the circulating water in the soil; if they are in the interior of particles, they cannot be made use of; while, if the particles are so pulverized that their constituents are exposed on their surfaces, they become available, because water can immediately attack to dissolve them and roots can absorb thein.

This is one of the great offices of plowing, harrowing, cultivating, and hoeing; the lumps of soil being thereby more broken up and exposed to the action of atmospheric influences, which are often necessary to produce a fertile condition of soil.

\section{SUBSOIL.}

The subsoil is usually of a different character from the surface soil, but this difference is more often the result of cultivation and the effect of vegetation than of a different original formation. The surface soil, 
from having been long cultirated, has been more opened to the influences of the air than is the case with the subsoil, which has nerer been disturbed so as to allow the same action. Again the growth of plants has supplied the surface soil with roots, which by decaying have given it organic matter, thus darkening its color, rendering it warmer, and giving it greater ability to absorb heat and moisture, and to retain manures. All of these effects render the surface soil more fertile than it was before regetable growth commenced, unless, by the removal of erops, its earthy plant-food has been too much reduced; and, where frequent cultivation and manures have been applied, a still greater benefit has resulted. In most instances the subsoil may, by the same means, be gradually improved in condition until it equals the surface soil in fertility. The means of producing this result, also further accounts of its advantages, will be given under the head of Cultivation (Sec. IV.).

\section{LMPROVEMENT.}

From what has now been said of the character of the soil, it must be erident that, as we know the causes of fertility and barrenness, we may by the proper means inprove the character of all soils which are not now in the highest state of fertility.

Chemical analysis of the soil cannot give us any reliable indication of its fertility or barrenness; so much depends on the state of solubility of the mineral plant-food, on the uniformity of its distribution 
through the soil, on the extent to which it is exposed on the surface of particles, and probably on other conditions concerning which we are in doubt, or of which we are entirely ignorant, that the mere weighing and measuring of the laboratory, has very little, if any, value to the practical farmer.

We can learn something of the capacities of the soil from the character of the plants which grow naturally upon it, and much more from its ability to produce larger crops of one kind than of another; something from the effect of different mineral manures upon plants growing on it.

The best use to which the farmer ean apply the teachings of chemistry is in making such improvements as the foregoing indications show to be necessary, and, above all, in giving to the soil for each crop, or for each rotation of crops, the full equivalent of the minerals that they take away.

An examination, such as any farmer may make, will show us its deficiencies in mechanical character, and we may apply the proper treatment to increase fertility. In some instances the soil may contain everything that is required, but not in the proper condition. For instance, in some parts of Massachusetts, there are nearly barren soils which show by analysis precisely the same chemical composition as the soil of the Miami valley of Ohio, one of the most furtile in the world. The cause of this great difference in their agricultural capabilities, is that the Miami soil has its particles finely pulverized; while in the Massachusetts soil the ingredients are com- 
bined within particles (such as pebbles, etc.), where they are out of the reach of roots.

In other cases, we find two soils, which are equally well pulverized, which are of the same color and texture, and which appear to be of the same character, yet liaving very different power to support crops. Chemical analysis, could it aceurately show, not only the kinds and quantities of plant food contained in these soils, but the condition in which it exists as to solnbility, etc., wonld undoubtedly indicate a very great difference between them.

All of these differences may be overcome by the use of the proper means. Sometimes it conld be done at an expense which would be justified by the result; and at others, it might require too large an outlay to be profitable. It becomes a question of economy, not of ability, and science is able to estimate the cost.

A soil cannot be cultivated understandingly until it has been rigidly subjected to such examinations as will tell us, as nearly as any examination can tell it, what is necessary to render it fertile. Eren after fertility is perfectly restored it requires thought and care to maintain it. The different ingredients of the soil must be returned in the form of manures as largely as they are removed by the crop, or the supply will eventually become too small for the purposes of vegetation. 


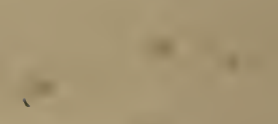

$+2$

-
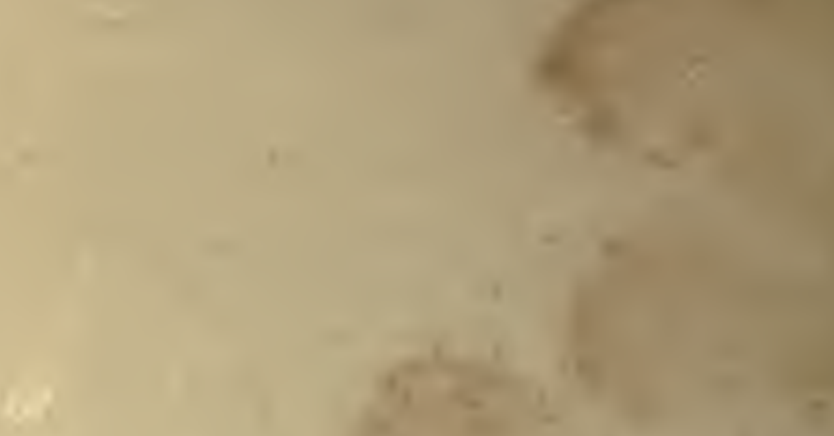


\section{A N URES.}


11

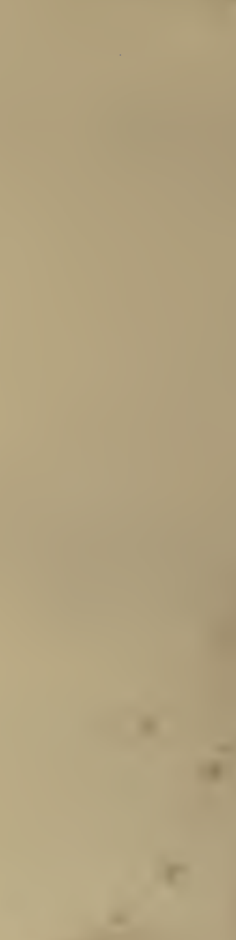

(5)

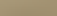


SECTION THIRD.

\section{A N U R ES.}

\section{CHAPTER I.}

CHARACTER AND VARIETIES OF MAN UR ES.

TuE study, of the science of manures is one of the most important branches of the practical education of a farmer. No baker would be called a good practical baker, who kept his flour exposed to the sun and rain. No shoemaker would be called a good practical shoemaker, who used morocco for the soles of his shoes, and heavy leather for the uppers. No carpenter would be called a good practical carpenter, who tried to build a house without nails, or other fastenings. So with the farmer. He cannot be called a good practical farmer if he keeps the materials, from which he is to make plants, in such a condition, that they will have their value destroyed, uses them in the wrong places, or tries to put them 
together without having everything present that is necessary. Before he can work to the best advantage, he must know what manures are composed of, how they are to be preserved, where they are needed, and what kinds are required. True, he may from observation and experience, guess at results, but he cannot know that he is right, and that he gets his results in the cheapest and most economical way, until he has learned the facts above named. In this section. of our work, we shall endeavor to convey some of the information necessary to this branch of practical farming.

We shall adopt a classification of the subject somewhat different from that found in most works on manures, but the facts are the same. The action of manures is either mechanical or chemical, or a combination of both. For instance: soine kinds of manure improve the mechanical character of the soil, such as those which loosen stiff clay soils, or others which render light sandy soils compact-these are called mechanical manures. Some again furnish food for plants-these are called chemical manures.

Many mechanical manures produce their effects by means of chemical action. Thus potash combines chemically with sand in the soil. In so doing, it roughens the surfaces of the particles of sand, and renders the soil less liable to be compacted by rains. In this manner, it acts as a mechanical manure. The compound of sand and potash,* as well as the potash alone, may enter into the composition of plants, and

* Silicate of potash. 
hence it is a chemical manure. In other words, potash belongs to both classes described.

It is important that this distinction should be well understood by the learner, as the words "mechanical" and "chemical" in connection with manures will be made use of through the following pages.

There is another class of manures which we shall call absorbents. These comprise those substanees which have the power of taking up fertilizing matters, and retaining them for the use of plants. For instance, charcoal is an absorbent. As was stated in the section on soils, this substance is a retainer of all fertilizing gases and of many minerals. Other matters made nse of in agriculture have the same effect. These absorbents will be spoken of more fully in their proper places.

\section{TABLE.}

Mechanical Manures are those which improve the mechanical conditions of Chemioal " soils are those which serve as food for plants.

\section{MANURES.}

Absorbents are those substances which absorb and retain fertilizing matters.

Manure may be divided into three classes, viz.: organic, mineral, and atmospheric. 
OrgaNic manures comprise all animal and vegetable matters which are used to fertilize the soil, such as dung, swamp-muck, etc.

Mineral manures are those which are of a purely mineral character, such as lime, ashes, etc.

Aturospherio manures consist of those organic manures which exist in the form of gases in the atmosphere, and which are absorbed by rains and carried to the soil. These are of the greatest importance. The ammonia and carbonic acid in the air are atmospheric manures.

\section{CHAPTER II.}

A N I A L EX R EMENT.

Tine first organic manure which we shall examine, is animal excrement.

This is composed of those matters which have been eaten by the animal as food, and have been thrown off as solid or liquid manure. In order that we may know of what they consist, we must refer to the composition of food and examine the process of digestion.

The food of animals, we have seen to consist of both atmospheric and earthy matters. The atmospheric part may be divided into two classes, i. e., that portion which contains nitrogen-such as glu- 
ten, albumen, etc., and that which does not contain nitrogen-such as starch, sugar, oil, etc.

The earthy part of food may also be divided into soluble matter and insoluble matter.*

\section{DIGESTION AND ITS PRODUCTS.}

Let us suppose that we have a full-grown ox, which is not increasing in any of his parts, but only consumes food to keep up his respiration, and to supply the natural wastes of his body. To this ox we will feed a ton of hay which contains organic matter, with and without nitrogen, and soluble and insoluble earthy substances. Now let us try to follow the food through its changes in the animal, and see what becomes of it. Liebig compares the consumption of food by animals to the imperfect burning of wood in a stove, where a portion of the fuel is resolved into gases and ashes (that is, it is completely burned), and another portion, which is not thoronghly burned, passes off as soot. In the animal action in question, the food undergoes changes which are similar to this burning of wood. A part of the food is digested and taken up by the blood, while another portion remains undigested, and passes the bowels as solid dung-corresponding to the soot of combustion. This part of the dung, then, we see is merely so much of the food as passes throngh the system

* No part of animal manure is permanently and entirely insoluble. It would perhaps be better to classify these substances as (1) those which are readily soluble, and (2) those which are but slowly soluble. 
without being materially changed. Its nature is easily understood. It contains organic and mineral matters in nearly the condition in which they existed in the hay. They have been rendered finer and softer, but their chemical character (their composition) is not materially altered. The dung also contains small quantities of nitrogenous matter, which has leaked out, as it were, from the stomach and intestines. The digested food, however, mindergoes further changes which affect its character, and it escapes from the body in three ways- $i$. e., throngh the lungs and skin, through the bladder, and through the bowels. It will be recollected from the first section of this book, p. 20 , that the carbon in the blood of animals unites with the oxygen of the air drawn into the lungs, and is thrown off in the breath as carbonic acid. The hydrogen and oxygen unite to form a part of the water which constitutes the moisture of the breath.

That portion of the atmospheric part of the hay which has been taken up by the blood of the ox, and which does not contain nitrogen, is emitted through the lungs. It consists, as will be recollected, of carbon, hydrogen, and oxygen, and these assume, in respiration, the form of carbonic acid and water.

The atmospheric matter of the digested hay, in the blood, which does contain nitrogen, goes to the Uladder, where it assumes the form of urea-a constituent of urine or liquid manure.

We have now disposed of the imperfectly digested food (the dung), and of the atmospheric matter which 
was taken up by the blood. All that remains to be examined is the earthy matter in the blood, whiel would have become ashes, if the hay had been burned. The readily soluble part of this earthy matter passes into the bladder, and forms the earthy parts of urine. The more insoluble part passes the bowels, in connection with the dung.

If any of the food taken $n p$ by the blood is not returned as above stated, it goes to form fat, muscle, hair, bones, or some other part of the animal, and as he is not growing (not increasing in weight) an equivalent amount of the body of the animal goes to the manure to take the place of the part retained.*

We now have our subject in a form to be readily understood. We learn that when food is given to animals it is not put out of existence, but is merely changed in form; and that in the impurities of the breath, we have a large portion of those parts of the food which plants obtain from air and from water; while the solid and liquid excrements contain all that was taken by the plants from the soil and from manures. The Solm Duag contains the undigested parts of the food, the more insoluble parts of the ash, and the nitrogenous matters which have escaped from the digestive organs.

* This account of digestion is not, perhaps, strictly accurate in a physiological point of view, but it is sufficiently so to gire an elementary understanding of the character of excrement as manture. 
The Liqum MANURE contains the nitrogenous parts of the digested food, and the soluble parts of the ash.

The Breatu contains those parts of the fully digested food which contain carbon, hydrogen, and oxygen, but no nitrogen, or at least a very ineonsiderable quantity of it.

\section{CHAPTER III.}

WASTE OF MANURE.

TuE loss of manure is a subject which demands most serious attention. Until within comparatively few years, little was known of the true character of manures, and consequently of the importance of protecting them against loss.

The chief causes of waste are evaporation and leaching.

\section{EVAPORATION.}

Evaporation is the changing of a solid or liquid body to a vapory form. Thus common smelling salts, a solid, if left exposed, passes into the atmosphere in the form of a gas or vapor. Water, a liquid, eraporates, and becomes a vapor in the atmosplere. 
This is the case with very many substances in organic nature, both solid and liquid: they are liable to assume a gaseous form, and become mixed with the atmosphere. They are not destroyed, but are changed in form.

As an instance of this action, suppose an animal to die and to decay on the surface of the earth. After a time, the flesh will entirely disappear, but is not lost. It no longer exists as the flesh of an animal, but its carbon, hydrogen, oxygen, and nitrogen, still exist in the air. They have been liberated from the attractions which held them together, and have passed away; but (as we already know from what has been said in a former section) they are ready to be again taken up by plants, and pressed into the service of life.

The evaporation of liquids may take place without the aid of anything but lieat; but, in the case of solids, it is often assisted by decay and combustion, which break up the bonds that hold the constituents of bodies together, and thus enable them to return to the atmosphere, from which they were originally derived.

It must be recollected that everything which has an odor (or can be smelled) is eraporating. The odor is caused by parts of the body floating in the air, and acting on the nerres of the nose. This is an invariable rule; and when we perceive an odor, we may be sure that parts of the material from which it emanates are escaping. If we perceive the odor of an apple, it is because parts of the rolatile oils of 
the apple enter the nose. The same is true when we smell hartshorn, cologne, etc.

The intensity of these odors bears no relation to the amomt of the substance passing into the air ; for instance, a grain of musk will continue to give off a strong odor for many years, while gum camphor, with a much less intense odor, wastes away very rapidly. Ammonia escapes rapidly.

Manures made by animals have an offensive odor, simply because volatile parts of the decomposing manure escape into the air, and are therefore made pereeptible. All organic parts in turn may become volatile, assuming a gaseous form as they decompose.

We do not see the gases rising, but there are many ways by which we can detect them. If we wave a feather over a manure heap, from which ammonia is escaping, the feather having been recently dipped in muriatic acid, white fumes will appear around the feather, being the muriate of ammonia formed by the union of the eseaping gas with the acid. Not only ainmonia, but also carbonic acid, and other gases which are useful to vegetation escape, and are given to the winds. Indeed it may be stated in few words that all of the organic part of plants (all that was obtained from the air, from water, and from ammonia), constituting more than nine-tenths of their dry weight, may be evaporated by the assistance of decay or combustion. The atmospheric parts of manures may be lost in the same manner; and, if the process of decomposition be continued long enough, nothing 
but a mass of earthy matter will remain, except a small quantity of carbon which has not been resolved into carbonic acid.

The proportion of solid manure lost by evaporation (made volatile by the assistance of decay) may be a rery large part of the whole. Manure cannot be kept a single day in its natural state without losing something. It commences to give out an offensive odor immediately, and this odor is often accompanied, as was before stated, by the loss of some of its fertilizing parts.

Animal manure contains, as will be seen by reference to p. 86, all of the substances contained in plants, though not always in the correct relative proportions to each other. When decomposition commences, the carbon unites with the oxygen of the air, and passes off as carbonic acid; the hydrogen and oxygen combine to form water (which evaporates), and the nitrogen is mostly resolved into ammonia, which escripes into the atmosphere, unless absorbed by substances artificially applied for the purpose, or retained by the earbon, organic acids, or other products of decomposition with which it may become united.

If manure is thrown into heaps, it often ferments so rapidly as to produce sufficien theat to set fire to some parts of the manure, and cause its gases to be thrown off with greater rapidity. This may be observed in nearly all heaps of animal excrement. When they have lain for some time in mild weather, gray streaks of ashes are often to be seen in the centre of 
the pile. The organic part of the manure having been burned away, nothing but the ash remains,this is called fire-fanging.

Manures kept in cellars without being mixed with refuse matter are subject to some loss by evaporation unless they are so situated as to absurb the urine, when they are less likely to become injuriously heated.

When kept in the yard, they are much more liable to loss from excessive evaporation. They are here often saturated with the water of rains, which, in its evaporation, carries away ammonia and carbonic acid which it has obtained from the rotting mass. The evaporation of the water is rapidly carried on, on aceount of the great extent of surface. The whole mass is spongy, and soaks the liquids up from below (through hollow straws, etc.), to be evaporated at the surface on the same principle as causes the wick of a lamp to draw up the oil to supply fuel for the flame.

LiquID Manure containing large quantities of nitrogen, and forming much ammonia, is also liable to lose all of its organic parts from evaporation (and fermentation), so that it is rendered as much less valuable as is the solid dung.

From these remarks, it may be justly inferred that a very large portion of the value of solid and liquid manure may be lost by evaporation in a sufficient length of time, depending on circumstances, whether it be a few months or several years. The wasting commenees as soon as the manure is dropped, and continues, except in very cold weather, until the destruction is complete. Hence we see that true 
economy requires that the manures of the stable, sty, and poultry-house, should be protected (as will be hereafter described) as soon as possible after they are made.

\section{LEACILNG.}

The subject of leaching is even more important in considering the earthy parts of manures than eraporation is to the atmospheric, while leaching also affects the atmospheric products of decay, they being absorbed by water to a great degree.

A good illustration of leaching is found in the manufacture of potash. When water is poured over wood-ashes, it dissolves their potash which it carries through in solution, making ley. If ley is boiled to dryness, it leaves the potash in a solid form, proving that this substance had been dissolved by the water and remored from the insoluble parts of the ashes.

In the same way, water in passing through manures takes up their soluble portions as fast as liberated by decomposition, and carries them to waste, and they are lost to the manure. There is but a small quantity of ash exposed for leaching in fresh dung; but, as the decomposition of the atmospheric part proceeds, it continues to derelop it more and more (in the same manner as burning would do, only more slowly), thus preparing fresh supplies to be carried off with each shower. In this way, while manure may be largely injured by evaporation, the soluble parts may be removed by water until but a small remnant of its original fertilizing properties remains. 
It is a singular fact concerning leaching, that water is able to carry no part of the organic constituents of vegetables to any considerable depth below the surface in a fertile soil. They would probably be carried to an unlimited distance in pure sand, as it contains nothing which is eapable of arresting them; but, in most soils, the clay and carbon which they contain retain all of the ammonia; also nearly all of the matter's which go to form the ashes of plants very near the surface of the soil. If such were not the case, the fertility of the earth must soon be destroyed, as all of those elements which the soil must supply to growing plants wonld be carried down ont of the reach of roots, and leave the world a barren waste, its surface having lost its elements of fertility, while the downward filtration of these would render the water of wells and springs unfit for our use. Now, however, they are all retained near the surface of the soil, and the water issues from springs comparatively pure.

Evaporation removes from manure-

Carbon, in the form of carbonic acid.

Hydrogen and oxygen, in the form of water.

Nitrogen, in the form of ammonia.

LeAcHrNG removes from manure-

The soluble and most valnable parts of the ash in solution in watèr, besides carrying away some of the abovenamed forms of organic matter. 


\section{CHAPTER IV.}

ABSORBENTS.

BEFore considering further the subject of animal excrement, it is necessary to examine a class of manures known as absorbents. These comprise all matters which have the power of absorbing (or soaking ip) the gases which arise from the evaporation of solid and liquid manures, and retaining them until required by plants.

The most important of these is undoubtedly clay, which forms a large part of nearly all fertile soils. The use of this in connection with manure will be spoken of in describing the treatment of night-soil. For ordinary use one of the most valuable absorbents is charcoal.

\section{CHARCOAL.}

Charcoal, in an agricultual sense, means all forms of carbon, whether as peat, muck, charcoal dust from the spark-catchers of locomotives, charcoal hearths, river and swamp deposits, leaf mould, decomposed spent tanbark or sawdust, etc. In slort, if any regetable matter is decomposed with the partial exclusion of air (so that there shall not be oxygen enough supplied to unite with all of the carbon), a portion of its carbon remains in the exact condition to perform the best agricultural offices of charcoal.

The operation of carbonaceous matter in the soil 
was explained in a former section (Sec. 2), and we will now examine merely its action with regard to manures. When properly applied to manures, in compost, it has the following effects :

1. It absorbs and retains the fertilizing gases evaporating from decomposing matters.

2. It acts as a divisor, thereby reducing the strength (or intensity) of powerful manures-thus rendering them less likely to injure the roots of plants; and also increases their bulk, so as to prevent fire-fanging in eomposts.

3. It in part prevents the leaching out of the soluble parts of the ash.

4. It keeps the compost moist.

The first-named oftice of chareoal, $i$. e., absorbing and retaining gases, is one of the utmost importance. It is this quality that gives to it so high a position in the opinion of all who have used it. As was stated in the section on soils, earbonaceous matter seems to be capable of absorbing everything which may be of use to vegetation. It is a grand purifier, and while it prevents offensive odors from escaping, it is at the same time storing its pores with food for the nourishment of plants.

2 d. In its capacity as a divisor for manures, charcoal is excellent in all cases, especially to use with strongly concentrated (or heating) animal manures. These, when applied in their natural state to the soil, are very apt to injure young roots by the violence of their action. When mixed with a divisor, such manures are diluted, made less actire, and conse- 
quently less likely to be injurious. In composts, manures are liable, as has been before stated, to become burned by the resultant heat of decomposition; this process of eombustion is prevented by the liberal use of divisors, becanse, by inereasing the bulk, the heat, being diffused through a larger mass, becomes less intense. The same principle is exhibited in the fact that it takes more fire to boil a eauldron of water than a tea-kettlefinll.

3d. Chareoal has much power to arrest the passage of mineral matters in solution; so much so, that compost heaps, well supplied with muek, are less affected by rains than those not so supplied. Ail eomposts, however, and all organie manures should be kept under cover until spread upon the land.

4th. Charcoal keeps the eompost moist, from the ease with which it absorbs water, and its ability to retain it.

With these advantages before us, we must see the importance of an understanding of the modes for obtaining chareoal. Many farmers are so situated that they ean obtain sufficient quantities of ehareoal dust. Others have not the same faeilities. Nearly all, however, can obtain muck or leaf mould, and to this we will now turn our attention.

MUCK AND ITS TREATMENT.

By muck, we mean the vegetable deposits of swamps and rivers. It consists of decayed organic 
substances, mixed with more or less earth. Its principal constituent is carbon, in different degrees of development, which has remained after the deeomposition of vegetable matter. Muck varies largely in its quality aceording to the amount of carbon which it contains, and the completeness of its decomposition. The best muck is usually found in comparatively dry locations, where the water whieh once cansed the deposit has been removed. Muck which has been long in this eondition, is usually better decomposed than that whieh is saturated with water. The muck from swamps, however, may soon be brought to the best condition. It should be thrown out if possible at least a year before it is required for use, and left in small heaps or ridges, exposed to the action of the weather, which will assist in pulverizing it, while, from having its water removed, its decomposition goes on more rapidly.

After the muek has remained in this condition a sufficient length of time, it may be removed to the barn-yard and composted with a mixtme of lime and salt (described on page 99 in the proportion of one cord of muck to four bushels of the mixture, or with slaked lime, or wood-ashes. At the end of a month or more, the muek in the compost will have been reduced to a fine pulverulent mass, the decomposition being hastened and made more complete by repeated turnings-nearly as valuable as charcoal dust for application to animal exerement. When in this eondition it is called prepared muck, by which name it will be designated in the following pages. 
Muck had better not be used immediately after being taken from the swamp, as it is then almost always sour. Its sourness is due to acids which it contains, and these must be rectified by the applieation of an alkali, or by long exposure to the weather, before the muek is suitable for use.

\section{LMIE AND SALT MIXTURE.}

The mixture, lime and salt, used in the decomposition of unuck, is made in the following manner:

RECIPE.-Take three bushels of shell lime, hot from the kiln, or as fresh as possible, and slake it with water in which one bushel of salt has been dissolved.

Care must be taken to use only so much water as is necessary to dissolve the salt, as it is diffieult to induce the lime to absorb even so large a quantity.

In dissolving the salt, it is well to hang it in a basket in the upper part of the water, as the salt water will immediately settle towards the bottom (being heavier), and allow the freshest water to be nearest to the salt. In this way the salt may be all dissolved, and thus make the brine used to slake the lime. It will be necessary to apply the brine at intervals of a day or two, and to stir the mass often, as the amount of water is too great to be readily absorbed.

This mixture should be made under cover, as, if exposed, it wonld obtain moisture from rain or dew, whiel would prevent the use of all the brine. 
Another objection to its exposure to the weather is its liability to be washed away by rains. It should be at least ten days old before being used. and wonld be improved by an age of three or four months, as the chemical changes it undergoes will require some time to be completed.

The eharacter of this mixture is not very clearly understood. Its principal constituents are lime, carbonic acid, chlorine, and soda. The salt is undoubtedly decomposed in part or entirely, and various compounds, containing the above substances in different proportions and in different forms of combination, are formed. Probably the extent of the decomposition of the salt and the character of the new combinations depend on various circumstanees, and vary considerably.

These compounds are much better agents in the composition of muck than pure salt and lime.

When shell lime eannot be obtained, Thomaston, or any other very pure lime, will answer; but care must be taken that it do not contain much magnesia.

\section{LIME.}

Mnck may be decomposed by the aid of other materials. Lime is very efficient, though not so much so as when combined with salt. The action of lime, when applied to the muck, depends very much on its condition. Air-slaked lime (carbonate of lime) has less effeet than hydrate of lime (lime simply slaked with water), because it is less canstic in its character. 


\section{POTASH.}

Potash is a very active agent in decomposing regetable matter, and may be used with great advantage, especially where the soil which is to be manured is deficient in potash.

Unleached wood-ashes are generally the best sonrce from which to obtain this, and from five to twentyfive bushels of these mixcd with one cord of muck will have a eapital effect."

The sparlings (or refise) of potash wareliouses may often be purcliased at sufliciently low rates to be used for this purpose, and answer an excellent end. They may be applied at the rate of from twenty to one hundred pounds to each cord of muek.

By any of the foregoing methods, muck may be prepared for use in composting.

\section{CHAPTER V.}

COMPOSTTNG STABLE MANURE.

Is composting stable manure in the most economical manner, the evaporation of the gases which result from its decomposition, and the leaching ont of the ashy (and other') portions which decomposition has

* Leached ashes will not supply the place of these, as the leaching has deprived them of most of their potash. 
set free must be aroided, while the mass is kept in such condition as to adinit of the perfect decomposition of the manure.

Solid manures in their fresh state are of but very little use to plants. It is only as they are decomposed, and have their nitrogen turned into ammonia, and their other ingredients prepared to be taken up again by plants, that they are of much value as fertilizers, although there are of course eertain advantages resulting from their fermentation in the ground, while there is no better way to aroid loss than by plowing fresh manure directly into the soil. We have seen that, if decomposition takes place without proper preeantions being taken, the most valuable parts of the manure would be lost. Nor is it advisable, when an immediate effect is wanted, to keep manures from deeomposing until they are applied to the soil, for then they are not immediately ready for use, and time is lost. By composting, we aim to save everything while we prepare the manures for immediate use.

\section{SHELTER.}

The first consideration in preparing for eomposting is to provide proper shelter. This may be done either by means of a shed or by arranging a cellar under the stables, or in any other manner that may be dictated by cireumstances. It is no doubt better to have the manure shed enclosed so as to make it an effectual protection; this, however, is not absolutely necessary if the roof project far enough over the 
compost to shelter it from the sun's rays and from driving rains.

The importance of some protection of this kind is evident from what has already been said, and indeed it is impossible to make an economical use of manures without it. The trifling cost of building a shed, or preparing a cellar, is amply repaid in the benefit resulting from their uses. If an open shed is used, care should be taken to so arrange the slope of the ground that no surface water can reach the manure.

\section{THE FLOOR.}

The floor or foundation on which to build the compost deserves some consideration. It may be of plank tightly fitted, a hard bed of clay, or better, a cemented surface. Whaterer material is used in its construction (and stiff clay mixed with water and beaten compactly down answers an excellent purpose), the floor must have such an inclination as will cause it to discharge water only at one point. That is, one part of the edge must be lower than the rest of the floor, which must be so shaped that water will run towards this point from every part of it; then-the floor being water-tight-all the liquids of the compost may be collected in a

\section{TANK.}

This tank, used to collect the liquids of the manure, may be made by sinking a barrel or hogshead (ac- 
cording to the size of the heap) in the ground at the point where it is required, or in any other convenient manner.

In the tank a pump of cheap construction may be placed, to raise the liquid to a sufficient height to be conveyed by a trough to the eentre of the heap, and there distributed. by means of a perforated board

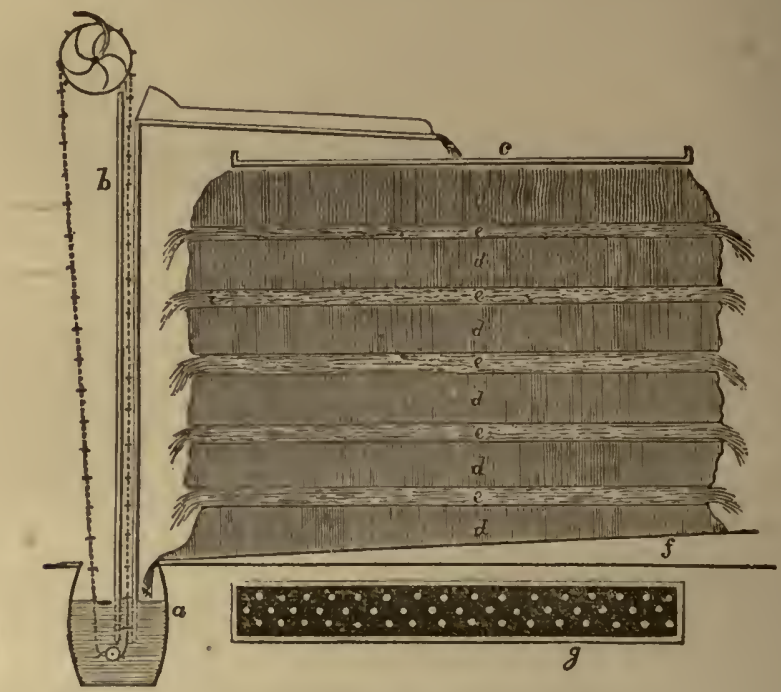

Fra. 2.

$a$, tank; $b$, pump ; $c$ and $g$, perforated board ; $d$, muck ; $e$, manure; $f$, floor.

with raised edges, and long enough to reach across the heap in any direction. By altering the position of this board, the liquid may be carried evenly over the whole mass. 
The appearance of the apparatus required for composting, and the compost laid up, may be better shown by the foregoing figure.

The compost is made by laying on the floor ten or twelve inches of muck, and on that a few inches of manure, then another heavy layer of muck, and another of manure, continuing in this manner until the heap is raised to the required height, always having a thick layer of muck at the top.

After laying up the lieap, the tauk should be filled with liquid manure from the stables, slops from the house, soap-suds, or other water containing fertilizing matter, to be pumped over the mass. There should be enough of the liquid to saturate the heap and filter through to fill the tank once or twice a week, at which intervals it should be again pumped up, thus continually being passed through the manure. This liquid should not be changed, as it contains much soluble manure. Should the liquid manures named above not be sufficient, the quantity may be increased by the use of rain-water. That falling during the first ten minutes of a shower is the best, as it contains the most ammonia.

The effects produced by frequently watering the compost constitute one of the greatest advantages of this system.

The soluble portions of the manure are equally diffused throngh every part of the heap.

Should the heat of fermentation be too great, the watering will reduce it.

When the compost is saturated with water, tho 
air is driven out; and, as the water subsides, fresh air enters and takes its place. The fresh air contains oxygen, which assists in the decomposition of the manure.

In short, the watering does all the work of forking over by hand much better and much more eheaply.

At the end of a month or more, this compost will be ready for use. The layers in the manure will have disappeared, the whole mass having become of a uniform character, highly fertilizing, and ready to be immediately used by plants.

It may be applied to the soil, either as a top-dressing, or otherwise, without fear of loss, as the muck will retain all of the gases which would otherwise evaporate.

The cost and trouble of the foregoing system of composting are trifling compared with its advantages. The quantity of the manure is inuch increased, and its quality improved. The health of the animals is secured by the retention of those gases, which, when allowed to escape, render impure the air that they have to breathe.

The cleanliness of the stable and yard is much improved, as the effete matters, which would otherwise litter them, are carefully removed to the compost.

The system of composting described above is the most complete that has yet been suggested for making use of solid manures. Many other methods may be adopted when circumstances will not admit of so much attention. It is a common and excellent practice to throw prepared muck into the eellar under 
the stables, to be mixed and turned over with the manure by swine. In other cases the manures are kept in the yard, and are covered with a thin layer of muck every morning. The principle which renders these systems bencficial is that of the absorbent power of charcoal.

The composting of stable manure, although always advantageons, frequently requires more labor, and more expensive accommodations than can be given to it. There is no doubt that, where proper facilities can be obtained for carrying ont the foregoing directions, they will be found profitable. Those who are obliged to use their stable manure with the least possible amount of handling, or who cannot procure muck or other organic matter to add to it, should at least manage to keep it entirely sheltered from the rain until it is hauled ont on to the land. Manure kept under a shed, necessarily loses some ammonia; but the amount of this loss has been found to be very small, for the reason that, during the decomposition of the straw and coarser regetable parts, certain organic acids and other compounds are produced, which combine with or absorb most of the ammonia as it is generated.

The loss of ammonia, and of the solnble constituents of the ash, is greater when the decomposition takes place without protection from the rain.

The best plan is, undoubtedly, to have a cellar under the stable to receire the manure as soon as dropped, and to protect it, as far as possible, from all atmospheric influences. 
For a long time one of the strongest recommendations of "book farming" was directed against the practice of spreading manure upon the land more than a day or two before it eonld be plowed under. But on this point, practice las gained a triumpl over a crude theory. There is no donbt that manure so spread is subject to some waste; but that which is not wasted is so much better incorporated with the soil by the water of rains, which distributes its soluble parts evenly among all of its particles, that the effeet prodneed is better than if the raw manure had been immediately plowed under, neeessarily somewhat irregularly and in spots. In this latter case there wonld be no loss of material, but some parts of the soil would receive more than was necessary, while others would be deprived of any material benefit, and the land would be less fertile than if every root were sure to find, in every part of the soil, its due proportion of the food. Ammonia is formed only during decomposition ; and, especially during eold weather, there is very little decomposition going on in manure which is thinly spread upon the surface of the land; hence the loss from this cause is not great.

In the case of very heavy mauuring, especially with undecomposed manure on elay land, there is a great benefit arising from the fermentation of the dung in the soil, - a chemical action producing a mechanieal effect, - but ordinarily it is at least a question whether it is not best to spread the manure on the surface as long as possible before plowing, 
unless in the case of land which is to be plowed in the fall for spring crops, when it is well to spread the manure after plowing, to be harrowed in in the spring.

This practice is of course not admissible on steep hill-sides or other surfaces where the manure would be subjected to the danger of being washed away by water flowing over the surface in winter or spring.

Different circumstanees necessarily require a different treatment of manure; but the following prineiples are applicable to all cases :

1. All organic manures are much improved by being thoroughly decomposed before being applied to the land.

2. It is always advantageous (thongh not always advisable) that their fermentation take place in the eompost heap, where they give a part of their valne to muck or other refuse organic matter, which prevents all waste of fertilizing gases.

3. All animal manures should be carefully protected against snn, rain, and wind, from the time they are dropped mitil they are spread upon the land.

4. The solid dung shonld always be so kept that it will absorb the urine.

5. For the mechanical improvement of the soil, raw manure should be deeply mixed with it.

6. For immediate fertilizing effect, well-rotted manure should be applied to, and harrowed in near the surface. 
LIQUID MANURE.

Liquid manure fiom animals may, also, be made useful by the assistance of prepared muck. Where a tank is used in composting, the liquids from the stable may all be employed to supply moisture to the lieap; but where any system is adopted, not requiring liquids, the mine may be applied to muck heaps, and there allowed to ferment. Fermentation is necessary in urine as well as in solid dung, before it is very active as a manure, althongh its decomposition is much more rapid than that of the dung. Urine, as will be recollected, contains nitrogen and forms ammonia on fermentation.

The urine shonld never be allowed to stand in pools to become mixed with rain-water, nor to run to waste; but should always be immediately absorbed either by the dung or by muck, or other refuse matter provided for the purpose.

By referring to the analysis of liquid and solid manure in Section V., their relative value may be seen.

\section{CHAPTER VI.}

DIFFERENT KINDSOF ANIMAL EXCREMENT.

The manures of different animals are, of course, of different value as fertilizers, varying according to the food, the age of the animals, etc. 
Yet the diflerence is not so great as would be supposed. The quality of manure depends very much more upon the food from which it is made than upon the animal by which it is made. Linseed meal or cotton-seed meal, which contains much nitrogen, and is rich in phosphates, makes manure worth infinitely more than that from straw and turnips. Whether these articles of food have passed throngh an ox or a hog, makes very little differenee; though, as explained below, it does make some difference.

\section{STABLE MA N R E.}

By stable manure we mean, usually, that of the horse, and that of horned eattle. 'The case described in Chapter II. (of this Section) was one where the animal was not increasing in any of its parts, but returned in the form of manure, and otherwise, the equivalent of everything eaten. This ease is one of the most simple kind, and is subjeet to many modifieations.

The growing animal is increasing in size, and as he derives his increase from his food, he does not return in the form of manure so much as he eats. If his bones are growing, he is taking from his food phosphate of lime and nitrogenous matter ; consequently, the manure will be poorer in these ingredients. The same may be said of the formation of the muscles, in relation to nitrogen.

The fattening animal, if finll grown, makes manure which is as good as that from animals that are not 
increasing in size, becarise the fat is taken from those parts of the food which are obtained by plants from the atmosphere, and from water $(i . e$. from the substances containing no nitrogen). Fat contains no nitrogen, and, consequently, does not lessen the amount of this ingredient in the inanure.

Milch Cows use a part of their food for the formation of milk, and consequently they produce manure of redueed value.

The solid manure of the horse is better than that of the ox, while the liquid manure of the ox is comparatively better than that of the horse. The cause of this is, that the horse has less perfect digestive organs than the ox, and consequently passes more of the valuable parts of his food, in an undigested form, as dung; while the ox, from ehewing the cud and having more perfect digestion, turns more of his food into urine than does the horse.

RECAPITULATION.

Fuld Grown animals not producing milk, and full grown animals fattening

make the best manure.

Tine Growiva of Antmals reduees the value of their manure, portions of their food being taken to form their bodies.

Mrrcir Cows reduce the value of their manure by changing a part of their food into milk. 
TuE Ox makes poor dung and rich urine.* The Horse makes rich dung and poor urine.*

NIGHT SOIL.

The best manure within the reach of the farmer is night soil, or human excrement. The manure of man consists (as does that of any other animal) of those parts of his food which are not retained in the increase of his body. If he be growing, his manure is poorer, as in the case of the ox; and it is subject to all the other modifications named in the early part of this chapter. His food is usually of a varied character, and is rich in nitrogen, the phosphates, and other inorganic constituents; consequently, his manure is made valuable by containing large quantities of these matters. As is the case with the ox, the dung contains the undigested food, the secretions (or leakings) of the digestive organs, and the insoluble parts of the ash of the digested food. The urine, in like manner, contains a large proportion of the nitrogen and the soluble inorganie parts of the digested food. When we consider how much richer the food of man is than that of horned cattle, we shall understand the superior value of his excrement.

Night soil has been used as a manure, for ages, in China and Japan; and herein lies, undoubtedly, the great secret of their snecess in supporting a dense population, for almost countless ages, without impoverishing the soil.

* Comparatively. 
Some have supposed that manuring with night soil would give disagreeable properties to plants: this is not the ease; their quality is invariably improved. The color and odor of the rose are made richer and more delicate by the use of the most offensive night soil as manure.

It is evident that this is the ease from the fact that plants have it for their direct object to make over and put together the refise organic matter and the gases and the minerals found in nature, for the use of animals. If there were no natural means of rendering the exerement of animals available to plants, the earth must soon be shorn of its fertility, as the elements of growth when once consumed would be essentially destroyed, and no soil could survive the exhaustion. There is no reason why the manure of man should be rejected by vegretation more than that of any other animal; and indeed it is not,-ample experience has proved that there is no better manure in existenee.

A single experiment will suffice to show that night soil may be so kept that there shall be no loss of its valuable gases, and eonsequently no offensive odor arising from it, while it may be removed and applied to crops without unpleasantness. All that is necessary to effect this wonderful change in night soil, and to turn it from its disagreeable eharacter to one entirely inoffensive, is to mix with it a little charcoal dust, prepared muek, dry earth, or any other good absorbent-thus making what is called poudrette. The mode of doing this must depend on cirenmstances. 
"Sereral plans have recently been devised which have for their object the improrement of privy accommodations of detached houses. One of these, the 'Earth Closet,' of the Rev. Henry Moule, an English clergyman, is at once so cheap, so simple, and so perfect in its operation, that it should receive general attention. Its action is based on the power of soils which contain clay or organic matter (loam or mould) to absorb all offensive effluvia. This power is so great that not only will a pint of sifted and air-dried earth completely deodorize the matters of a single exacuation, but if aried in the air after each use, the same pint of earth may be used over and over again-losing, apparently, none of its power of absorption-until it finally becomes as powerful a manure as Peruvian guano-although entirely inoffensive to the sight and smell." *

The manure thus made is of the most valuable character, and may be used under any circumstances with a certainty of obtaining a good crop.

For an analysis of human manure, see Section $\bar{V}$.

\section{HOG MLANURE.}

Hog manure is very valuable, but it must be used with care. It is very liable to make cabbages clumpfooted, and to induce a disease in turnips called anbury (or fingers and toes). It is so violent in its action that, when applied to crops in a pure state, it

* From an article on Sewers and Earth Closets, in the American Agricultural Annual, for 1868, by Geo. E. Waring, Jr. 
often produces injurious results. The only precantion necessary is to supply the sty with prepared muck, charcoal-dust, leaf-inould, eartl, or any absorbent in plentiful quantities, often adding fresh supplies. The hogs will work this over with the manure; and, when required for use, it will be found an exeellent fertilizer. The absorbent will have overcome its injurious tendeney, and it may be safely applied to any erop, except cabbages and the smoothleaved turnips-such as the rutabaga. From the variety and rich character of the food of this animal, his manure is of a superior quality.

- Butchers' hogpen manure is one of the best fertilizers known. It is made by animals that live chiefly on blood and other animal refuse, and is very rich in nitrogen and the phosphates. It should be mixed with prepared muck, or its substitute, to prevent the loss of its ammonia, and as a protection against its injurious effect on plants.

\section{POULTRY-HOCSE MANURE.}

Next in value to night soil, among domestic manures, are the excrements of poultry, pigeons, etc. Birds live on the nice bits of creation, seeds, insects, ete., and they discharge their solid and liquid exerements together. Poultry-dung is nearly equal in value to Peruvian guano (except that it contains more water), and it deserves to be carefully preserved and judiciously used. It is as well worth one dollar per bushel as guano is worth seventy-five dollars a ton. 
Poultry-manure is liable to as much injury from eraporation and leaching as is any other manure, and equal care shonld be taken (by the same means) to prevent such loss. Good shelter over the roosts, and frequent sprinkling with prepared muek or chareoal-dust, will be amply repaid by the increased value of the manure, and its better action and greater durability in the soil. The principle npon which Moule's Earth Closet is based may be very effectively applied to the ponltry-house. All that is necessary is to dig or fork up the earth floor of their lodging-room as often as may be necessary (say once a week), and to rake it daily so as to mix the fresh droppings with the loose earth. In this manner the floor of the poultry-house, for a depth of eight or ten inches, may be made to absorb the droppings of a whole suminer so as to entirely prevent offensive smells or disease, while the earth for that depth will be worth many times what it has cost.

The ralue of this manure should be taken into eonsideration in ealeulating the profit of keeping poultry (as indeed with all other stock). It has been observed by a gentleman of much experience, in poultry raising, that the yearly manure of a hundred fowls applied to previously unmanured land would produce extra corn enough to keep them for a year. This is probably a large estimate, but it serres to show that this fertilizer is very valuable, and also that poultry may be kept with great profit, if their excrements are properly secured. 
The manure of pigeons has been a favorite fortilizer in some countries for more than 2,000 years.

Market gardeners in England attach much valnc to rabbit-manure.

\section{SHEEP MANURE.}

The manure of sheep is less valuable than it would be if so large a quantity of the nitrogen and mineral parts of the food were not employed in the formation of wool. This has an effect on the richness of the excrements, but they are still of very great value as a fertilizer, and should be protected from loss in the same way as stable-manure.

\section{G U A N O .}

Guano as a manure has become world renowned. The worn-out tobacco lands of Virginia, and other fields in many parts of the country, which seemed to have yielded to the effect of an ignorant course of cultivation, and to have sunk to their final repose, have in many cases been revived to the production of excellent crops, and have had their value multiplied many fold by the use of guano. Although an excellent inanure, it should not cause us to lose sight of those valuable materials which exist on almost every farm. Every ton of guano imported into the United States is an addition to our national wealth, but every ton of stable-manure, or poultry-dung, or night soil evaporated or carried away in rivers, is equally a deduction from our riches. If the inported manure is to really benefit us, we must not allow it to 
occasion the neglect and consequent loss of our domestic fertilizers.

The Peruvian guano (which is considered the best) is brought from islands off the coast of Peru. The birds which frequent these islands live almost entirely on fish, and drop their excrements here in a climate where rain is unknown, and where, from the dryness of the air, there is but little loss sustained by the manure. It is brought to this country in large quantities, and is an excellent fertilizer, superior even to night soil.

Injudiciously used, Peruvian guano may become a curse to a country instead of a blessing. It stimulates crops to an inordinate growth and causes them, on the poorer soils, to seek out the last available atom of some mineral which it does not in itself supply in sufficient quantity. When this last atom has been sold off in the crop, the power of the guano to produce a crop, to which that mineral is largely necessary, has ceased. It is not the guano, but the crop that has exhausted the land. If all its mineral constituents had been judiciously returned, the soil would not be made poorer, - on the contrary, it would be made better by the decomposition of the roots left in the soil. The best wày to use guano, is to compost it with other manures or to mix it with fine earth or nuck. In either case, its lumps should be crushed to powder, so that it may be evenly distributed through the soil.

The composition of various kinds of guano may be found in the Section on Analysis. 


\section{CHAPTER VII.}

OTHER ORGANIC MANURES.

THE number of organic manures is almost countless. The most common of these have been deseribed in the previous chapters on the excrements of animals. The more prominent of the remaining ones will now be considered. As a universal rule, it may be stated that all organie matter (everything which has had vegetable or animal life) is capable of feeding plants.

\section{DEAD ANIIALS.}

The bodies of animals contain much nitrogen, as well as large quantities of the phosphates and other inorganic materials required in the growth of plants. On their decay, the nitrogen is resolved into ammonia, and the mineral matters become valuable as food for the inorganic parts of plants.

If the decomposition of animal bodies takes place in exposed situations, and without proper precautions, the ammonia escapes into the atmosphere, and much of the mineral portion is leached out by rains. The use of absorbents, such as charcoal-dust, prepared muck, earth, etc., will entirely prevent the evaporation, and will in a great measure serve as a protection against leaching.

If a dead horse be cut in pieces and mixed with ten loads of muck, the whole mass will, in a single season, become a valuable compost. Small animals, such as dogs, cats, etc., may be with advantage 
buried by the roots of grape-rines, or trecs, or composted as above.

BONES.

The bones of animals contain phosphate of lime and gelatine. The gelatine is a nitrogenous substance, and prodnces anmonia on its decomposition. This subject will be treated more fully under the head of "plosphate of lime" in the chapter on mineral manures, where the treatment of bones is considered more directly with reference to the fertilizing value of their earthy parts.

FISH.

In many localities near the sea-shore large quantities of fish are caught and applied directly to the soil. These make excellent manure. They contain much nitrogen, which renders them strongly ammoniacal on decomposition. Their bones consist of phosphate and carbonate of lime; and, being naturally soft, they decompose in the soil with great facility, and become available to plants. The scales of fish contain valuable quantities of nitrogen, etc., all of which are highly useful.

Refuse fishy matters from markets and from the house are well worth saving. These and fish caught for manure may be made into compost with prepared muck, or earth, etc.; and as they putrefy rapidly, they soon become ready for use. They may be added to the compost of stable manure with great advantage. 
Fish (like all other nitrogenons manures) should never be applied as a top dressing, unless previously mixed with a good absorbent of ammonia ; but shonld, when used alone, be immediately plowed under to considerable depth, to prevent the evaporation-and consequent loss - of their fertilizing gases.

Within the past few years the manufacture of oil from fish has become a very extensive industry, especially along the coast of New England. The fish are eaught in immense quantities and delivered to the factories, where they are first cooked by steaming and then subjected to very heavy pressure, which removes their oil. The solid matter which is left behind, containing the bones, scales, and muscular tissues, is run through a "pieker," and sold for manure. It contains all of the fish that is of value for this purpose, in a very eoncentrated form, and it is easy of applieation to the soil. It is now sold for about one-third of the value of Peruvian grano, at which price it is a much more economical fertilizer.

WOOLLEN RAGS, ETC.

Woollen rags, hair, waste of woollen factories, ete., contain both nitrogen and phosphate of lime; and, like all-other matters containing these ingredients, are excellent manures, but they must be used in such a way as to prevent the escape of their fertilizing gases. They deeompose slowly, and are therefore considered a lasting manure. Like all lasting manures, however, they are slow in their effects, and the most ad- 
vantageous way to use them is to eompost them with stable manure, or with some other rapidly fermenting substance, which will hasten their decomposition and render them sooner available.

Rags, hair, etc., thus treated, will in a short time be redueed to such a condition that they may be more immediately used by plants instead of lying in the soil to be slowly taken up. It is better in all cases to have manures act quickly and give an immediate return for their cost, than to lie for a long time in the soil before their influence is felt.

Old leather should not be thrown away. It decomposes very slowly, and consequently is of but little value; but, if put at the roots of young trees, it will in time prodnce appreciable effects.

Tanners' and curriers' refuse, and all other animal offal, including that of the slaughter-house, are well worth attention, as they contain more or less of those two most important ingredients of manures, nitrogen and phosphate of lime.

It is unnecessary to add that, in common with all other animal manures, these substances must be either composted, or immediately plowed under the soil. Horn piths, and horn shavings, if deeomposed in compost with substances which ferment rapidly, make very good manure, and are worth fully the price charged for them.

ORGANIC MANURES OF VEGETABLE ORIGIN.

Muck, the most important of the purely regetable manures, has been already sufficiently described. 
It should be particularly borne in mind that, when first taken from the swamp, it is often sour, or cold; but that if exposed for a long time to the air, or if well treated with lime, unleached ashes, the lime and salt mixture, or any other alkali, its acids will be noutralized (or overcome), and it becomes a good application to any soil, except peat or other soils already containing large quantities of organic matter.

\section{SPENT TAN-BARK.}

Spent tan-bark, if previously decomposed by the use of alkalies, answers all the purposes of prepared muck, but is more difficult of decompositiun.

The bark of trees contains a larger proportion of earthy matter than the wood, and much of this, on the decomposition of the bark, becomes available as manure. The chemical effect on the bark, of using it in the tanning of leather, is such as to render it difficult to be rotted by the ordinary means; but by the use of alkalies it may be reduced to the finest condition, and becomes a most excellent manure. Unless tan-bark be composted with lime, or some other alkali, it may produce injurious effects from the tannic acid which it still contains. Alkaline substances will neutralize this acid, and prevent it from being injurious.

One great benefit resulting from the use of spent tan-bark, is due to its power of absorbing moisture from the atmosphere. For this reason it is very val- 
uable for mulching* young trees and plants when first set out.

\section{SAWDEST AND SOOT.}

Sawdust in its natural state is of rery little value to the land, but when decomposed, as may be done by the same method as was described for tan-bark, it is of some importance, on account of the carbon that it contains. Its ash, too, which becomes available, contains soluble earthy matter, and in this way it aets as a direct manure. So far as coneerns the value of the ash, however, bark is superior to sawdust. Sawdust may be partially rotted by mixing it with strong inanure (such as that of the logpen), while it acts as a divisor, and prevents its too rapid action when applied to the soil. Some kinds of sawdust, such as that from beech-wood, form acetic acid on their decomposition, and these shonld be treated with, at least, a sufficient quantity of lime to correct the acid.

Soot is a good manure. It contains much earbon, and has, thus far, all of the beneficial effects of charcoal dust. The sulphur, which is one of its constituents, not only serves as food for plants, but, from its odor, affords a good protection against some insects. A handful of soot thrown orer a melon vine, or young cabbage plant, will keep away many insects.

Soot contains some ammonia, and as this is in the form of a sulphate, it is not rolatile, and conse-

* See the glossary at the end of the book. 
quently does not evaporate when the soot is applied as a top dressing, which is the almost universal custom.

\section{GREEN CROPS.}

Green crops, to plongh under, are in many places largely raised, and are always beneficial. The plants most used for this purpose, in this country, are clover, buckwheat, and peas. These plants have very long roots, which they send deep in the soil to draw up mineral matter for their support. This mineral matter is deposited in the plant. The leares and roots receive carbonic acid very largely from the air, and from the water in the soil. In this manner they obtain their carbon. When the crop is turned under the soil, it deeomposes, and the carbon, as well as the mineral ingredients obtained from the subsoil, are deposited in the surface soil, and become of use to succeding crops. The hollow stalks of the buckwheat and pea help to loosen the soil.

Altlough green crops are of great benefit, and require but little labor, they do require, as usually managed, that the use of the land and the expense of seeding and cultivation be entirely devoted to the advantage of future erops.

Very nearly the same benefit, especially in the case of clover, would result from the roots alone of a crop which has been eut for hay and again for seed. This at least is the opinion of many who have had much experience, and who believe that, by the decomposition of the roots only of a heavy crop 
of elover, the soil may be bronght to the highest state of fertility of which it is capable. The cropping of the plant canses an increased growth of the roots, and these, when plonghed up, and allowed to decompose in the soil, constitute an excellent manure, acting both ehemically and mechanically, and permanently increasing the value of the land.

If the system of cultivation adopted on the farm does not admit of the nse of green crops, its condition may be improved, though more expensively and less completely, by the application of swamp muck or leaf mould, and by the use of the subsoil plough, to loosen the lower soil. Except, however, in these comparatively rare eases, where all the land is needed for use every year, and where extensive manuring is adopted, the liberal use of green crops is always to be recommended.

Before elosing this ehapter, it may be well to remark that there are varions other fertilizers, such as the ammoniacal liquor of gas-houses, socpers' wastes, bleachers' lye, lees of old oil-casks, etc., which we have not space to consider at length, but which are all valuable as additions to the compost heap, or as applieations, in a liquid form, to the soil.

In many cases (when heavy manuring is practised) it may be well to apply organic manures to the soil in argreen state, turn them under, and allow them to undergo decomposition in the ground. The advantages of this system are, that the heat resulting from the chemieal changes, will hasten the growth of plants by making the soil warmer; the 
carbonic aeid formed will have a beneficial chemical action in the soil, and will be directly presented to the roots instead of escaping into the atmosphere; and if the soil be heary, the decomposing matters will tend to loosen it, and leave it more porous. As a general rule, however, in ordinary farming, where the amount of manure applied is only sufficient for the supply of food to the erop, it is undoubtedly better to have it previonsly decomposed,-cooked as it were, for the uses of the plants, -as they can then obtain the required amount of nutriment as fast as needed.

\section{ABSORPTION OF MOISTURE.}

It is often convenient to know the relative power of different manures to absorb moisture from the atmosphere, especially when we wish to mannre lands that suffer from dronght. The following results are given by C. W. Johnson, in his essay on salt (pp. 8 and 19). In these experiments the animal manures were employed without any admixture of straw.

1000 parts of horse-dung, dried in a temperature of $100^{\circ}$, absorbed by exposure for three hours to air saturated with moisture, of the temperature of

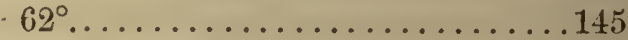

1000 parts of eow-dung, under the same circumstances, absorbed. . ........130

1000 parts pig-dung................... . . . . . . . . . . . . . . . .

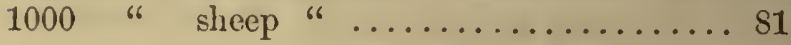


PARTS.

1000 parts pigeon-dung.............. 50

1000 " rich alluvial soil............. 14

1000 " fresh tanner's bark.............115

1000 " putrefied " $\ldots \ldots \ldots \ldots . \ldots 145$

1000 " refuse marine salt sold as manure.. $49 \frac{1}{2}$

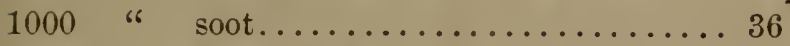

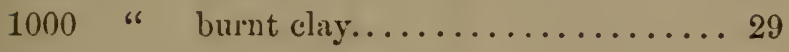

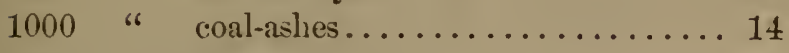

1000 " lime.................... 11

1000 " sediment from salt-pans........ 10

1000 " crushed rock salt............ 10

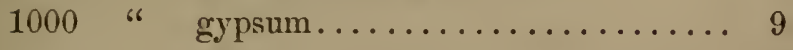

1000 " salt.................. 4

Muck is a most excellent absorbent of moisture, when thoroughly decomposed.

\section{DISTRIBUTION OF MANURES.}

The following table from Johnson on Manures, will be found convenient in the distribution of manures.

By its assistance the farmer will know how many loads of manure he requires, dividing each load into a stated number of heaps, and placing them at certain distances. In this manner manure may be applied evenly, and calculation may be made as to the amount, per acre, which a certain quantity will supply. 


\begin{tabular}{|c|c|c|c|c|c|c|c|c|c|c|c|}
\hline \multirow{2}{*}{\multicolumn{2}{|c|}{$\begin{array}{c}\text { DISTANOE } \\
\text { OF } \\
\text { THE HEAPS. }\end{array}$}} & \multicolumn{10}{|c|}{ NUNBER OF IIRAPS IN A LOAD. } \\
\hline & & 1 & 2 & 3 & 4 & 5 & 6 & 7 & 8 & 9 & 10 \\
\hline & yas & & 269 & 179 & 134 & 108 & $9 \frac{1}{2}$ & 77 & 7 & 60 & \\
\hline & & 5 & 168 & 132 & 99 & 19 & 0 & $56 \frac{1}{2}$ & $9 \frac{1}{2}$ & 44 & \\
\hline & d & 303 & 151 & 101 & $75 \frac{1}{3}$ & $60 \frac{1}{2}$ & $50 \frac{1}{2}$ & $43 \frac{1}{4}$ & $7 \frac{8}{4}$ & $33 \frac{1}{2}$ & \\
\hline & de & 239 & 120 & $79 \frac{1}{2}$ & $60^{\circ}$ & $47 \frac{8}{4}$ & $39 \frac{9}{4}-x-1-2-1$ & 341 & 30 & $26 \frac{1}{2}$ & \\
\hline & & 194 & 97 & $64 \frac{1}{2}$ & $48 \frac{1}{2}$ & 38 & $32 \frac{1}{4}$ & $27 \frac{8}{4}$ & $24 \frac{1}{4}$ & $21 \frac{1}{2}$ & 1 \\
\hline $5 \frac{1}{2}$ & do & 16 & 8 & $53 \frac{1}{2}$ & 40 & $32^{*}$ & $26 \frac{3}{4}$ & $3 \frac{8}{4}$ & 20 & $17 \frac{8}{4}-x-x-5$ & 10 \\
\hline & & 13 & 67 & $44 \frac{8}{4}$ & $33 \frac{1}{2}$ & 2 & $22 \frac{1}{2}$ & $19 \frac{1}{4}$ & 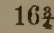 & $15^{2}$ & $1:$ \\
\hline $6 !$ & & 115 & $57 \frac{1}{2}$ & 381 & 28 & 2 & 19 & $16 \frac{1}{t}$ & $14 \frac{1}{4}$ & $12 \frac{8}{1}$ & 1. \\
\hline & & 99 & $49 \frac{1}{2}$ & 33 & 248 & 198 & $16 \frac{1}{2}$ & 1 & $12 \frac{1}{5}$ & 11 & 10 \\
\hline $7 \frac{1}{2}$ & & 8 & 43 & 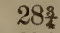 & $21 \frac{1}{2}$ & 1 & $14 \frac{1}{5}$ & 121 & $10 \frac{8}{4}$ & $9 \frac{1}{2}$ & \\
\hline & & 75 & 378 & 251 & $19^{\circ}$ & & $12 \frac{1}{2}$ & 10 & & & \\
\hline$\delta_{2}$ & $a$ & 67 & $33 \frac{1}{2}$ & 221 & $16 \frac{8}{4}$ & $13 \frac{1}{2}$ & $11 \frac{1}{4}$ & $9 \frac{1}{2}$ & $8 \frac{1}{2}$ & $7 \frac{1}{2}$ & \\
\hline & & 60 & 30 & $20^{\circ}$ & 15 & 12 & 10 & 8 & & $6 \frac{3}{4}$ & \\
\hline 9. & $\mathrm{dc}$ & $53 \frac{1}{2}$ & $26 \frac{8}{4}$ & 18 & $13 \frac{1}{2}$ & 10 & 9 & $\sqrt{4}$ & $6 \frac{7}{4}$ & 6 & 5 \\
\hline 0 & 00. & $48 \frac{1}{2}$ & 241 & 164 & 12 & $9 \frac{8}{4}$ & 8 & 7 & 6 & $5 !$ & 4 \\
\hline
\end{tabular}

Example 1.-Required the number of loads necessary to manure an acre of ground, dividing each load into six heaps, and placing them at a distance of $4 \frac{1}{2}$ yards from each other. The answer by the table is 39 ?

Example 2.-A farmer has a field containing $5 \frac{1}{2}$ acres, over which he wishes to spread 82 loads of dung. Now 82 divided by $5 \frac{1}{2}$, gives 15 loads per acre; and by referring to the table, it will be seen that the desired object may be accomplished by making 4 heaps of a load, and placing them 9 yards apart, or by 9 heaps at 6 yards, as may be thought advisable.

\section{CIIAPTER VIII.}

MINERAL II A N U RES.

Tre second class of manures named in the general division of the subject, in the early part of this section, comprises those of a mineral eharacter. 
These manures have four modes of action when applied to the soil.

1st. They furnish food for the mineral part of plants.

2d. They prepare matters already in the soil for assimilation by roots.

3d. They improve the mechanical condition of the soil.

4th. They absorb ammonia.

Some of the mineral manures produce in the soil only one of these effects, and others are efficient in two or more of them.

The principles to be considered in the nse of mineral manures are essentially given in the first two sections of this book. It may be well, however, to repeat them briefly in this connection, and to give the reasons why any of these manures are needed,from which we may learn what rules are to be obserred in their application.

1st. Those which are used as food by plants. It will be reeollected that the ash left after burning plants, and which formed a part of their structures, has a certain chemical composition; that is, it consists of alkalies, acids, and neutrals. It was also stated that the ashes of plants of the same kind are always of about the same composition, while the ashes of different kinds of plants may vary materially. Different parts of the same plant too, as we learned, are supplied with different kinds of ash.

For instance, clover, on being burned, leaves au ash containing lime, as one of its principal ingre- 
dients, while the ash of potatoes eontains more of potash than of anything else.

In the second section, (on soils,) we learned that some soils eontain everything necessary to make the ashes of all plants, and in sufficient quantity to supply what is required, while other soils are either entirely deficient in one or more ingredients, or contain so little of them in an available condition, that they are unfertile for certain plants.*

The different requirements of different plants is the foundation of the theory of special manuring;

* In all cases in which the constituents of the soil are spoken of in this book, it should be understood as applying not so much to its absolute chemical composition as to the availability of its plant-feeding parts. An atom of potash may be locked up in the inside of a pebble, and be of no more use to the roots of a plant than if it were a hundred miles away, yet a careful chemical analysis would destroy the pebble and weigh its atom of potash. The food of plants in the soil must exist in what Liebig calls "a state of physical combination," that is, coating the outside of its particles; attached to them by a feeble attraction which is sufficient to prevent their being washed away by the water of rains, but which yields to the feeding action of roots. It is his belief, and the opinion seems well founded, that it is only, or chiefly from materials so placed, that plants derive their food; and that the constituents of the soil, before they are taken up by roots, must be separated from their firmer relations and exposed on the surfaces of particles, as above stated.

In like manner those elements of manures which are taken up by the plant are first dissolved in water, from which they are absorbed by the particles of the soil,-spread over its intcrior surfaces, exposed to the action of roots.

Even the ammonia brought from the atmosphere in falling rain, attaches itself in the same way to the interior surfaces of the soil. 
which is that on a soil of tolerable fertility we can grow large crops of any particular plant by using such manures as are chiefly required for its ashes, as phosphoric acid for a crop of wheat, for instance, or potash for potatoes or tobaceo.

As a universal rule, it may be stated that to render a soil fertile for any particular plant, we must supply it (unless it already contains them) with those matters which are neeessary to make the ash of that plant; and, if we would render it eapable of producing all kinds of plants, it must be furnished with the materials required in the formation of all kinds of regetable ashes.

To carry out this system, howerer, with much nicety or certainty, would require a more thorough knowledge of the composition of the soil and of the feeding of plants than we yet possess. The only safe rule is, by the use of manures and of thorough enltiration, to make the soil fertile for all erops; and then to keep it fertile by the return of all mineral matters removed in its produce.

A long aequaintance with any field will show its strong and its weak points, and the greatest skill of the farmer should be applied to strengthening its weaker ones and preventing its stronger ones from becoming weaker: In this way the soil may be raised to its highest state of fertility, and be fully maintained in its productive powers.

2d. Those manures which render available the matters already contained in the soil.

Silicie acid, (or sand,) it will be recollected, exists 
in all soils; but, in its pure state, is not capable of being dissolved, and therefore eannot be used by plants. The alkalies (as has been stated) lave the power of eombining with it, making compounds, which are ealled silicates. These are readily dissolved by water, and are available in vegetable growth. Now, if a soil is deficient in these soluble silicates, it is well known that grain, ete., grown on it, not being able to obtain the material which gives them strength, will fall down or lodge; but, if such measures be taken as will render the sand soluble, the other conditions of fertility being present, the straw will be strong and healthy. Alkalies used for this purpose, come under the head of those manures which develop the natural resources of the soil.

Again, much of the mineral matter in the soil is combinel within particles, and is therefore out of the reach of roots. Lime, among other things, has the effect of causing these particles to crumble and expose their constituents to the demand of roots. Therefore, lime has for one of its offices the derelopment of the fertilizing ingredients of the soil.

$3 \mathrm{~d}$. Those manures which improve the mechanical condition of the soil.

The alkalies, in combining with sand, eommence their action on the surfaces of the particles, and ronghen them-rust them, as it were. This roughening of particles of some soils prevents them from moving anong each other as easily as they do when they are smooth, and thus keeps the ground from being compacted by heavy rains, as it is liable to be in its 
natural condition. In this way, the mechanical texture of the soil is improved.

It has just been said that lime canses the pulverization of the particles of the soil ; and thus, by making it finer, it improves its mechanical condition.

Some mineral manures, such as plaster and salt, have the power of absorbing moisture from the atmosphere; and this is a mechanical improvement to dry soils.

4th. Those mineral manures which have the powrer of absorbing ammonia.

Plaster, chloride of lime, alumina (clay), cte., are large absorbents of ammonia, whether arising from the fermentation of animal manures or washed down from the atmosphere by rains.

Having now explained the reasons why mineral manures are necessary, and the manner in which they produce their effects, we will proceed to examine the various deficiencies of soils and the character of various kinds of this class of fertilizers.

\section{CHAPTER IX.}

DEFICIEXTCIES OF SOILS, MEAYS OF RESTORATION, ETC.

As will be seen by referring to the analyses of soils on p. 63, they may be deficient in certain ingredients, which it is the object of mineral manures to supply. These we will take mp in order, and endea- 
vor to show in a simple manner the best means of managing them in practical farming.

\section{A L K A L I E S.}

POTASII.

Potash is often deficient in the soil. Its deficieney may have been caused in two ways. Either it may not have existed largely in the rock from which the soil was formed, and consequently is equally absent from the soil itself, or it may have once been present in sufficient quantities, and been carried away in crops, without being returned to the soil in the form of manure, until too little remains in an available form for the requirements of fertility.

In either ease the deficiency must be made up; it may be supplied by the farmer in various ways. Potash, as well as all the other mineral manures, is contained in the excrements of animals, but not (as is also the case with the others) in sufficient quantities to restore the proper balance to soils where it is largely deficient, nor even to make up for what is yearly removed with each erop, unless that crop (or its equivalent) has been fed to such animals as return all of the fertilizing constituents of their food in the form of manure, and this to be all carefully preserved and applied to the soil. In all other cases, it is necessary to apply more potash than is contained in the excrements of the animals of the farm.

Wood ashes is generally the most available source 
from which to obtain this alkali. The ashes of all kinds of wood eontain potash (more or less, according to the kind-see analyses, Section V.) If the ashes are leached, much of the potash is removed; and hence, for the purpose of supplying it, they are less valuable than unleached ashes. The latter may be made into compost with muck, as directed in a previons chapter, or applied directly to the soil. In either case the potash is available directly to the plant, or is capable of nniting with the silica in the soil to form silicate of potash. Leaehed ashes contain too little potash to be valuable in the compost, but, from their imperfeet leaching, they do contain enough to make them valuable as manure. Neither potash nor any other alkali shonld ever be applied to animal manures unless in compost with an absorbent, as they canse the ammonia to be thrown off and lost.

Potash sparlings, or the refuse of potash warehonses, is an excellent manure for lands deficient in this constituent.

Feldspar, kaotin, and other minerals eontaining potash, are, in some loealities, to be obtained in sufficient quantities to be used for manurial purposes.

Within a comparatively few years, a new fertilizer - of great value to all regions within carrying distance of its plaee of deposit-has been brought to the notice of farmers near the seaboard. This is the Green Sand Mrarl of New Jersey, which underlies a wide belt extending from the Atlantic Ocean to the Delaware River, having an area of about 900 square miles. It is very largely nsed in South Jersey, 
where it has given great value to land that was previously not fit for cultivation. Quite reeently, companies have been formed for its shipment to other places near the coast, and it promises to become of great importance wherever it can be cheaply proented.

An analysis of this manure is given in Section $\mathrm{V}$

SODA.

Soda, the requirement of which is occasioned by the same causes as create a deficiency of potash, and all of the other ingredients of regetable ashes, may be very readily supplied by the use of common salt (chloride of sodium), which is about one-half sodium (the base of soda). The best way to use salt is in the lime and salt mixture, previonsly described, or as a direct application to the soil. If too much salt be given to the soil it will kill any plant. In small quantities, however, it is highly beneficial, and if six bushels per acre be sown broadcast over the land, to be carried in by rains and dews, it will not only destroy many insects (grubs and worms), but will prove an excellent manure. Salt acts directly in the nutrition of plants, as a source of necessary chlorine and soda. There is little donbt, howerer, that its chief value as a manure in most instances arises from the fict that it renders other plant foods more soluble, and assists in preparing them for use. Salt, eren in quantities large enough to denude the soil of all vegetation, is never permanently injurious. After 
a time it seems to have the effect of increasing fertility. One peck of salt in eneh cord of compost will not only hasten the decomposition of the manures, but will kill seeds and all grubs-a very desirable effect. While small quantities of salt in a compost heap are beneficial, too much (as when applied to the soil) is positively injurious, as it arrests decomposition, fairly pickles the manures, and prevents them from rotting.

For asparagus, which is a marine plant, salt is an excellent manure, and may be applied in almost unlimited quantities, while the plants are growing; if used after they have gone to top, it is injurious. Salt has been applied to asparagus beds in such quantities as to completely corer them, and with apparent benefit to the plants. Of course large doses of salt kill all weeds, aud thus sare labor, and avoid the injury to the asparagus buds which would result from their removal by hoeing. Salt may be used adrantageonsly in any of the foregoing manners, but should always be applied with care. For ordinary farm purposes, it is undonbtedly most profitable to use the salt with lime, and make it perform the double duty of assisting in the decomposition of vegetable matter, and fertilizing the soil.

Soda unites with the silica in the soil, and forms the valuable silicate of soda.

Nitrate of soda, or enbical nitre, which is found in South America, is composed of soda and nitric acid. It furnishes both soda and nitrogen to plants, and is an excellent manure. 


\section{LIIE.}

The subject of lime is one of most vital importance to the farmer; indeed, so raried are its modes of action and its effects, that some writers hare given it credit for everything good in the way of farming, and have gone so far as to say that all permanent improvement of agrieulture must depend on the nse of lime. Although this is far in excess of the truth (as lime cannot plough, nor drain, nor supply anything but lime to the soil), its many bencficial effects demand for it the closest attention.

As food for plants, lime is of considerable importance. All plants eontain it-some of them in large quantities. It is an important constituent of straw, meadow hay, leaves of fruit-trees, peas, beans, and turnips. It constitutes more than one-third of the ash of red elover. Most soils contain lime enough for the use of plants; in others it is deficient, and must be supplied artificially before they ean produce good crops of those plants of which lime is an important ingredient. The amount required for the mere feeding of plants is not large (much less than one per cent.), but lime is often necessary for other purposes; and setting aside, for the present, its feeding action, we will examine its various effects on the mechanical and ehemical condition of the soil.

1. It corrects acidity (sourness).

2. It hastens the decomposition of the organic matter in the soil. 
3. It causes the mineral particles of the soil to crumble.

4. By producing the above effects, it prepares the constituents of the soil for assimilation by plants.

5. It is said to exhaust the soil; but as it does so through its beneficial action in producing larger crops, and only in this way, it is only necessary to return to the soil the other earthy ingredients that the larger crops remove from it.

1. The decomposition of organic matter in the soil, especially if too wet, often produces acids which make the land sour, and cause it to produce sorrel and other weeds, and which interfere with the healthy growth of crops. Lime is an alkali, and if applied to soils suffering from somruess, it will unite with the acids, and neutralize them, so that they will no longer be injurious.

2. We have before stated that lime is a deeomposing agent, and hastens the rotting of muck and other organic matter. It has the same effect on the organic parts of the soil, and causes them to be resolved into the gases and minerals of which they are formed. It has this effect, especially, on organic matters containing nitrogen, causing them to produce ammonia; consequently, it liberates this gas from the animal manures in the soil.

3. Various earthy compounds in the soil are so affected by lime that they lose their power of holding together, and crumble, or are reduced to finer particles, while some of their constituents are rendered soluble. This crumbling effect improves the 
mechanical as well as the cliemical condition of the soil.

4. We are now enabled to see how lime prepares the constituents of the soil for the use of plants.

By its action on the roots, buried stubble, and otlier organic matter in the soil, it causes them to be decomposed, and to give up their constituents for the use of roots. In this manner the organic mattcr is prepared for use more rapidly than it would be, if there were no lime present to liasten its decomposition.

By the decomposing action of lime on the mineral parts of the soil (3), they also are placed more rapidly in a useful condition than would be the case, if their preparation depended on the slow action of atmospheric influences.

Thus we see that lime, aside from its use directly as food for plants, exerts a beneficial influence on both the organic and inorganic parts of the soil.

5. Many farmers assert that lime exhausts the soil.

If we examine the manner in which it does so, we shall see that this is no argument againstits use.

It exhausts the organic parts of the soil by decomposing them, and resolving them into the gases and minerals of which they are composed. The gases arising from the organic matter cannot escape; because there is in all arable soils a sufficient amount of clay and carbonaceous matter present to cause these gases to be retained until required by the roots of plants. Hence, although the organic matter of manure and vegetable substances may be altered in 
form by the use of lime, it can escape (except in rery poor soils) only as it is taken up by roots to feed the crop, and such exhaustion is certainly profitable, and, so far as the organic parts are eoncerned, the fertility of the soil will be fully maintained by the decomposition of new roots and of organic manures.

The only way in which lime ean exhanst the earthy parts of the soil is, by altering their condition, so that plants ean use them more readily. That is, it exposes it to the action of roots. We have seen that fertilizing matter eannot be leached out of a good soil, in any material quantity, nor ean it be earried down to any considerable depth. Hence, there can be no loss in this direction; and, as mineral matter cannot evaporate from the soil, the only way in which it ean escape is through the structure of plants.

If lime is applied to the soil, and increases the amount of crops grown by preparing for use a larger supply of earthy matter, of course, the removal of earthy substances from the soil will be more rapid than when only a small erop is grown, and the soil will be sooner exhausted,- - not by the lime, but by the plants. In order to make up for this exhaustion it is necessary that a sufficient amount of inorganic matter be supplied to eompensate for the increased quantity taken away by plants.

Thus we see that it is hardly fair to accuse the lime of exhansting the soil, when it only improves its character, and increases the yield. It is the crop that takes away the fertility of the soil (the same as 
would be the case if no lime were used, only faster, because the crop is larger), and in all judicious enltivation this loss will be fully compensated by the application of manures, thereby prerenting the exhaustion of the soil.

Kind of lime to be used. The first consideration in procuring lime for manuring land, is to select that which contains but little, if any, magnesia. Nearly all stone lime contains more or less of this, but sone kinds contain more than others. When magnesia is applied to the soil in too large quantities, it is positively injurious to plants, and care is necessary in making seleetion. As a general rule, it may be stated, that the best plastering lime makes the best manure. Such kinds only should be used as are known from experiment not to be injurious.

Shell lime is undoubtedly the best of all, for it contains no magnesia, and it does contain a small quantity of phosphate of lime. In the vicinity of the sea-coast, and near the lines of railroads, oyster shells, clam shells, etc., can be cheaply procured. These may be prepared for use in the same manner as stone lime.

The preparation of the lime is done by first burning and then slaking, or by putting it directly on the land, in an unslaked condition, after its having been burned. Shells are sometimes ground, and used without burning; this is hardly advisable, as they cannot be made so fine as by burning and slaking. As was stated in the first section of this book, lime usually exists in nature, in the form of carbo- 
nate of lime, as limestone, chalk, or marble (being lime and carbonic acid combined), and when this is burned the carbonic acid is thrown off, leaving the lime in a pure or eaustic form. This is called burned lime, quick-lime, lime-shells, hot lime, etc. If the proper quantity of water be poured on it, it is immediately taken up by the lime, which falls into a dry powder, ealled slaked lime. If quick-lime were left exposed to the weather it would absorb moisture from the atmosphere, and beeome what is termed air-slakied.

When slaked lime (consisting of lime and water) is exposed to the atmosphere, it absorbs carbonic acid, and becomes carbonate of lime again; but it is now in the form of a very fine powder, and is much more useful than when in the stone, or even when finely ground.

If quick-lime is applied directly to the soil, it absorbs first moisture, and then carbonic acid, becoming finally a powdered carbonate of lime.

One ton of carbonate of lime eontains $11 \frac{1}{4} \mathrm{ewt}$. of lime; the remainder is earbonie acid. One ton of slaked lime contains about 15 ewt. of lime; the remainder is water.

Hence we see that lime should be burned, and not slaked, before being transported, as it would be unprofitable to transport the large quantity of earbonic acid and water contained in carbonate of lime and slaked lime. The quick-lime may be slaked and carbonated after reaching its destination, either before or after being applied to the land. 
As has been before stated, much is gained by slaking lime with salt water. Indeed, in many cases it will be found profitable to use all lime in this way. Where a direct action on the inorganic matters contained in the soil is desired, it may be well to apply the lime directly in the form of quiek-lime; but, where the decomposition of the vegetable and animal constituents of the soil is desired, the correction of sourness, or the supplying of lime to the crop, the mixture with salt would be advisable.

The amount of lime required by plants is, as was before observed, usually small compared with the whole amount contained in the soil ; still it is not unimportant.

25 bus. of wheat contain about OF LIME.

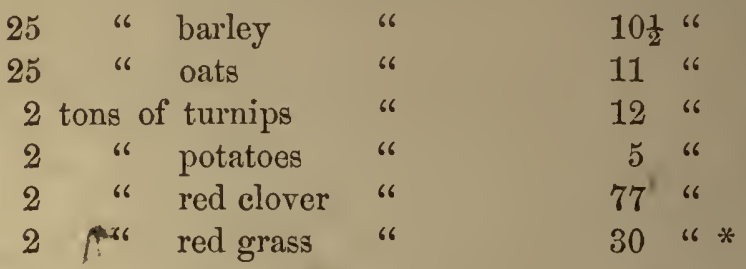

The amount of lime required at each application, and the frequency of those applications, must depend on the chemical and mechanical condition of the soil. No exact rule can be given, but probably the custon of each district-regulated by long expcrience-is the best guide.

Lime sinks in the soil; and therefore, when * The straw producing the grain, and the turnip and potato tops, contain more lime than the grain and roots. 
used alone, should always be applied as a top dressing to be earried into the soil by rains. The tendency of lime to settle is so great that, when cutting drains, it may often be observed in a whitish streak on the top of the subsoil. After heavy doses of lime have been given to the soil, and have settled so as to have apparently ceased from their action, they may be brought up and mixed with the soil by decper plowing.

Lime should never be mixed with animal manures, unless in eompost with muck or some other good absorbent, as it causes the escape of their ammonia.

PLASTER OF PARIS.

Plaster of Paris or Gypsum (sulpliate of lime) is composed of sulphuric acid and line in combination.

It is a constituent of many plants. It also furnishes them with sulphurie acid, and with the sulphur of which a small quantity is contained in sceds, etc.

It is an excellent absorbent of ammonia, and is very useful to sprinkle in stables, poultry houses, pig-styes, and privies, where it absorbs the escaping gases, saving them for the use of plants, and purifying the air-rendering stables, etc., more healthy than when not so supplied.

\section{CMLORTDE OF LIME.}

Chloride of lime contains lime and chlorine. It furnishes both of these, constituents to plants, and is 
an excellent absorbent of ammonia and other gases arising from decomposition-hence its usefulness in destroying bad odors, and in preserving fertilizing matters for the use of erops.

It may be used like plaster, or in the decomposition of organic matters, where it not only. hastens decay, but absorbs and retains the escaping gases.

Lime in combination with phosphoric acid forms the valuable phosphate of lime, of which so large a portion of the ash of grain, and the bones of animals, is formed. This will be spoken of more at length under the head of "phosphoric acid."

\section{MAGNESLA.}

Magnesia is a constituent of vegetable ashes, and is almost always present in the soil in sufficient quantities.

$\triangle \mathrm{CIDS}$.

SULPHURIO ACID.

Sulphuric acid is a very important constituent of vegetable ashes. It is sometimes deficient in the soil, particularly where potatoes have been long cultivated. One of the reasons why plaster (sulphate of lime) is so beneficial to the potato crop is probably that it supplies it with sulphuric acid.

Sulphuric acid is comnonly known by the name of oil vitriol, and may be purchased for agrienltural purposes at a low price. It may be added in a very 
dilute form (weakened by mixing it with a large quantity of water) to the compost heap, where it will change the ammonia to a sulphate as soon as formed, and thus prevent its loss, as the sulphate of ammonia is not rolatile; and, being soluble in water, is useful to plants. Some idea of the value of this compound may be formed from the fact that manufacturers of manures pay a high price for sulphate of ammonia, to insure the success of their fertilizers. Notwithstanding this, many furmers persist in throwing away hundreds of ponnds of ammonia every year, as a tax for their ignorance (or negligence), while a small tax in money-not more valuable nor more necessary to their success-for the support of common schools, and the better education of the young, is too often unwillingly paid.

If a tumbler full of sulphurie acid (costing a few cents) be thrown into the tank of the compost heap once a month, the benefit to the manure would be very great.

Care is necessary that too much sulphuric acid be not used, as it wonld prevent the proper decomposition of the manure.

In many instances it will be found profitable to use sulphuric acid in the manufacture of superphosphate of lime (as directed under the head of "phosphoric acid"), thus making it perform the donble purpose of preparing an available form of phosphate, and of supplying sulphur and sulphuric acid to the plant. 
PHOSPHORIC ACID.

We come now to the consideration of one of the most important of all subjects connected with agrienlture.

Phosphoric acid, which forms about one-half of the ashes of wheat, rye, corn, buck-wheat, and oats ; nearly the same proportion of those of barley, peas, beans, and linseed; an important part of the ashes of potatoes and turnips, one-quarter of the ash of milk, and a very large proportion of the bones of animals, often exists in the soil in the proportion of only abont one or two pounds in a thousand, and but a very surall part even of this anount is in a condition to be taken up by roots. The eultivation of our whole country has been such, as to take away the phosphoric acid from the soil without returning it, except in very minute quantities. Every hundred bushels of wheat sold contains (and remores permanently from the soil) about sixty pounds of phosphoric acid. Other grains, as well as the root crops and grasses, remove, likewise, a large quantity of it. It has been said by a contemporary writer, that for each cow kept on a pasture through the summer, there is carried off in veal, butter, and cheese, not less than fifty lbs. of phosphate of lime (bone-earth) on an average. This would be one thousand $l b s$. for twenty cows; and it shows clearly why old dairy pastures become so exhausted of this substance, that they will often no longer produce those nutritious grasses which are favorable to butter and cheese making. 
That this removal of one of the most valuable constituents of the soil has been the cause of more exhaustion of farms, and more emigration, in search of fertile distriets, than any other single effect of injudicious farming, is a fact which multiplied instances most clearly prove.

It is stated that the Genesee and Mohawk valleys, which onee produced an average of thirty-five or forty bushels of wheat per acre, have since been reduced, in their average production, less than twenty bushels. Hundreds of similar cases might be stated; and in a large majority of these, could the cause of the imporerishment be ascertained, it would be found to be the remoral of the phosphoric acid from the soil.

The evident tendency of cultivation being to continue this ruinons system, and to prey upon the vital strength of the country, it is necessary to take such measures as will arrest the outflow of this valuable material. This ean never be fully accomplished until the laws which regulate the nutrition of plants are generally understood and appreciated by the people at large. The enormous waste of the most valuable manures, taking place not only in every city, but about every residence in the land, can ouly be arrested when the importance of restoring to the soil a full equivalent for what is taken from it is universally realized. China and Japan, the most densely peopled countries in the world, have been cultivated for thousands of years with no diminution of their fertility. Japan is about as large and about 
as densely peopled as Great Britain, yet while Great Britain imports immense quantities of grain, guano, bones, and other fertilizers, and pours its immense volumes of manure into the sea, Japan neither wastes nor imports. The bread of its people is raised on its fields, which have been cultivated for uncounted ages, while every scrap of fertilizing matter is saved with scrupulous care.

It is true that the processes by which manure is saved and applied in China and Japan are not niee, but it is saved, nevertheless, and the faet that our chemieal knowledge enables us to accomplish the same result in an inoffensive manner, should make us all the more earnest in mending our ways.

Many suppose that soils which produce good crops, year after year, are inexhanstible, bnt time invariably proves the contrary. They may possess a sufficiently large stock of phosphoric acid, and other plant constituents, to last a long time, but when that stock becomes so reduced that there is not enough left for the uses of full crops, the productive power of the soil will yearly decrease, until it becomes worthless. It may last a long time-a century, or even morebut is long as the system is to remove everything, and return nothing, the fate of the most fertile soil is certain.

As has been stated already, the constituent of the soil which is most likely to become deficient is phosphoric acid. One principal source from which this can be obtained is found in the bones of animals.

These contain a large proportion of phosphate of 
lime. They are the receptacles which collect nearly all of the phosphates in erops which are fed to animals, and are not returned in their excrements. For the grain, etc., sent out of the country, there is no way to be repaid except by the inportation of this material; but nearly all that is fed to animals may, if a proper use be made of their exclement, and of their bones after death, be returned to the soil. With the treatment of animal excrements we are already familiar, and we will now turn our attention to the subject of

\section{BONES.}

Bones consist, when dried, of about one-third organic matter, and two-thirds eartlyy matter.

The organie matter consists chiefly of gelatine-a compound containing nitrogen.

The earthy part is chiefly phosphate of lime.

Hence we see that bones are excellent, both as organic and as mineral manure. The organic part, containing nitrogen, forms ammonia, and the inorganic part supplies the much-needed phosphoric acid to the soil.

Liebig says that, as a producer of ammonia, 100 lbs. of dry bones are equivalent to 250 lbs. of human urine.

Bones are applied to the soil in almost every coneeivable form. Whole bones are often used in very large quantities; their action, however, is extremely slow, and it is never advisable to nse them in this form. 
Ten bushels of bones, finely ground, will produce larger results, during the ten year's after applieation, than would one hundred bushels merely broken; not because the dust contains more fertilizing matter than the whole bones, but beeause that which it does contain is in a much more available condition. It ferments readily, and produces ammonia, while the ashy parts are exposed to the action of roots.

It is a rule which is applicable to all manures, that the more finely they are pulverized or divided, the more valuable they become. Not only do they expose much more surface to the feeding action of roots, but from their fine division they can be much more evenly distributed through the soil. If it is true, as seems probable, that the absorptive power of fertile soils is so strong as to prevent dissolved plant food from being carried beyond the point with which it first comes in contact, until the soil about that point has taken up all that it is capable of holding, then the more widely we spread a manure before it is dissolved, the more uniformly rich will be the soil. By sowing coarsely crushed bones, we fertilize the soil in spots. By crushing each lump we not only inake all of its constituents immediately available, but we make it reach every part of the surface between the spots above referred to. Even Peruvian guano, soluble as it is in water, is much more effective when finely ground before being spread upon the land.

Bone-black. If bones are burned in retorts, or otherwise protected from the atmosphere, their or- 
ganic matter will all be driven off except the earbon, which not being supplied with oxygen cannot eseape. In this form bones are called ivory black, or bone black; and they contain all of the earthy matter and earbon of the bones. The nitrogen having been expelled, it can make no ammonia; and thus far the original value of bones is reduced by burning - that is, a ton of bones contains more fertilizing matter before, than after, burning. This means of pulverizing bones is not to be recommended for the use of farmers, who should not lose the ammonia forming a part of bones, more than that of other manure.

Composting bones with ashes is a good means of securing their decomposition. They should be placed in a water-tight ressel (such as a ensk); first, three or four inches of bones, then the same quantity of strong unleached wood ashes, continuing these alternate layers until the cask is full, and keeping them always wet. If they become too dry they will throw off an offensire odor, aceompanied by the escape of ammonia, and consequent loss of value. In about one year, the whole mass of bones (except, perhaps, those at the top) will be softened, so that they may be easily crushed, and they are in a good condition for applieation to the land. The ashes are, in themselves, raluable, and this compost is excellent for many crops, particularly for Indian corn. A little dilute sulphuric acid, oceasionally sprinkled on the upper part of the matter in the cask, will prerent the escape of the ammonia.

Boiling bones under pressure, whereby their gela- 
tine is dissolved away, and the earthy matter left in an available eondition, from its softness, is a very good way of rendering them useful; but it requires the use of a steam boiler, and other expensive apparatus.

\section{SUPER-PIOSPIIATE OF LIME.}

Super-phosphate of lime is made by treating phosphate of lime, or the ashes of bones, with sulphurio acid.

Phosphate of lime, as it exists in bones, consists of one equivalent of phosphoric acid and three equivalents of lime.

The word "equivalent" is here used to represent what in ehemistry is known as the combining proportion of each element of a compound body-that is, one pound of one substanee combines with one and one-half pounds of another, and these proportions are invariable.

In bone earth, or phosphate of lime, one equivalent, or $72 \mathrm{lbs}$. of phosphorie aeid eombines with three equivalents (of $28 \mathrm{lbs}$. each), or $84 \mathrm{lbs}$. of lime. Now, by adding to this eompound one equivalent (or $40 \mathrm{lbs}$.) of sulphuric acid, we cause one equivalent (28 lbs.) of the lime to be taken away, leaving the $72 \mathrm{lbs}$. of phosphoric acid combined with only $56 \mathrm{lbs}$. of lime. By using two equivalents of sulphurie acid (or so lbs.) we cause the removal of $56 \mathrm{lbs}$. of lime, leaving only $28 \mathrm{lbs}$. eombined with the $72 \mathrm{lbs}$. of phosphoric acid. This is super-phosphate of lime, which is readily soluble in water. It 
is united with $80 \mathrm{lbs}$. of sulphuric acid and $56 \mathrm{lbs}$. of lime in combination with each other, forming $136 \mathrm{lbs}$. of sulphate of lime, or plaster-of-paris.

The whole compound contains :

Phosphoric acid......... 72 lbs.

Sulphuric acid............ s0 "

Lime............... 84 "

In all........... $\overline{236}$ "

-or, $25 \frac{18}{100}$ per cent. of phosphoric acid.

The phosphoric acid, now in combination with only one equivalent of lime, is readily dissolred in water, and will be evenly distributed in the soil; but it will take the earliest opportunity to combine with two more equivalents of lime in the soil, and will again become insoluble. It may well be asked, What is the advantage of making it soluble if it is so soon again to become insoluble?

The answer to this question is elearly stated in the following quotation from Prof. S. W. Jolmson's Essays on Manures:-

"This white cloud is precipitated bone-phosphate of lime, and does not essentially differ from the original bone-phosphate, except that it is inconceivably finer than can be obtained by any mechanieal means. The particles of the finest bone-dust will not average smaller than one-hundredth of an inch, while those of the precipitated phosphate are not more than one twenty-thonsandth of an inch in diameter. Since the particles of the precipitated phosphate are so very much smaller than those of the 
finest bone-dust, we can understand that their action as a manure would be eorrespondingly more rapid."

In saying that the phosphate of lime is insoluble, it is meant that it is insoluble in pure water. Water which contains either carbonic acid, ammonia, or common salt (and all soil water contains one or more of these), has the power of dissolving it, and making it available to roots. The action is slow, but it is sufficient, and it is the more rapid the finer the pulverization of the phosphate. The fine preeipitated phosphate exposes much more surface to the action of the water, and can consequently be taken up much more rapidly.

Super-phosphate of lime may be made from whole bones, bone-dust, bone-black, or from the pure ashes of bones, or from phosphatic gnano.

The reason why super-phosphate of lime is better than phosphate, is therefore easily explained. The phosphate is very slowly soluble in water, and consequently furnishes food to plants slowly. A piece of bone as large as a pea may lie in the soil for years without being all consumed; consequently, it will be years before its value is returned, and it pays no interest on its cost while lying there. The super-phosphate is very rapidly dissolved, and if evenly spread is diffused by the water of rains thronghont the soil,coating its absorbent particles with a nutriment held in a state of physical combination, ready to be yielded to the action of roots; hence its much greater value as a manure.

It is true that the phosphate is a more lasting 
manure than the super-phosphate-in the same way that gold buried in a pot in the garden is more lasting than if used in labor and manure for its cultivation. I desire, once for all, to eaution farmers against attaching too much imporance to the lasting qualities of a manure. Gencrally they are lasting only in proportion as they are lazy. In manuring, as in other things, a nimble sixpence is better than a slow shilling.

Of course it is not to be understood that all manures used had better exert their full effect on the first year's erop, but the more rapidly it can be made arailable consistently with the course of cultivation adopted (the rotation, etc.), the less we shall lose in the item of interest. A hundred pounds of coarsely ground bones may give an extra crop of $250 \mathrm{lbs}$. of hay per year for ten years. The same quantity finely grome and evenly spread might add a thousand lbs. to the first year's crop, and if the hay is consumed on the farm, and its constituents returned in the form of manure, the same increase might be received year after year. Therefore, in considering the value of manure, more attention should be given to the rapidity of its aetion than to the time that it will last. Many farmers who have the proper facilities, may find it expedient to purchase bones or bone-dust and sulphuric acid, and to manufacture their own super-phosphate of lime; others will prefer to purchase the prepared manure. Such purchases should be made witl great care, and only from persons of established reputation, for nothing is easier 
than the adulteration of this material. It is best, always, to stipulate that the manure shall eontain a certain pereentage of soluble and insoluble phosphorie acid,- - and to withhold payment until an arerage sample of the manure received has been tested by a competent chemist.

\section{SILICIO ACID.}

Silicic acid (or sand) always exists in the soil in sufticient quantities for the supply of food for plants ; but not always in the proper eondition. This subjeet has been so often explained to the reader of this book, that it is only neeessary to repeat here, that when the weakness of the straw or stalk of plants grown on any soil indicates an inability in that soil to supply the silicie aeid required for strength, not more sand should be added, but alkalies, to eombine with the sand already contained in it, and make soluble silicates which are available to roots.

Sand is often necessary to stiff clays, as a mechanical manure, to loosen their texture and render them easier of cultivation, and more favorable to the distribution of roots, and to the eirculation of air and water, and in this eapacity it is often very important. In my own practice I find it profitable to haul it three miles to use on heavy clay land.

NEUTRALS.

CHLORINE.

Chlorine, a necessary eonstituent of plants, and sometimes, though not usually, deficient in the soil, 
may be applied in the form of salt (chloride of sodium), or chloride of lime. The former may be dissolved in the water used to slake lime, and the latter may, with much advantage, be sprinkled around stables and other plaees where fertilizing gases are eseaping, and, after being saturated with ammonia, applied to the soil, thus serving a double purpose. On a stock farm, a very good way to return to the soil the chlorine contained in the produce sold, is to give it freely to the animals.

\section{OXIDE OF IRON.}

Probably all soils contain sufticient quantities of oxide of iron, or iron rust, so that this substance can hardly be required as a manure.

Some soils, however, contain the protoxide of iron in such quantities as to be injurious to plants,--see page 74 . When this is the case, it is necessary to plow the soil thoronghly, and use such other mechanical means as shall open it to the admission of air. The protoxide of iron will then take up more oxygen, and become the peroxide-which is not only inoffensive, but is conducive to fertility.

OXIDE OF MAYGANESE.

This can hardly be called an essential constitnent of plants, and is never taken into consideration in manuring lands. 
VARIOUS OTHER EARTHY MANURES.

LEACIIED ASIIES.

Among the earthy manures which have not yet been mentioned, - not coming strictly under any of the preceding heads,-is the one known as leached ashes.

These are, of course, mich less valuable than ashes from which the potash has not been leached out; still, as potash is generally made, the leaching is not very complete, and a considerable quantity of this substance, available to plants, is left in them. In addition to this, they contain some phosphoric acid and silicic acid, which add to their value. Practically, they are held in high esteem in all localitics where they can be obtained at a moderate cost of transportation. Care, however, should be taken, not to purchase ashes which have been made in lime-kilns, as these generally contain a large quantity of lime, which is not worth so high a price as the ashes.

$\because$

OLD MORTAR.

Old mortar is a valuable manure, because it contains not only lime, but compounds of nitric acid with alkalies,-called nitrates.

These are slowly formed in the mortar by the changing of the nitrogen of the hair (in the mortar) and of the ammonia received from the atmosphere into nitric acid, and the union of this with the 
lime of the plaster, or with other alkalies which it may contain in minute quantities.

The lime contained in the mortar may be useful in the soil for the many purposes accomplished by other lime, and is generally more valuable than that fresh from the kiln.

GAS HOUSE LIHE, ETC.

The refuse lime of gas works, where it can be cheaply obtained, may be advantageously used as a manure. It consists, chiefly, of various compounds of sulphur and lime. It shonld be composted with earth or refuse matter, so as to expose it to the aetion of air. It should never be used fresh from the gas house. In a few months the sulphur will have united with the oxygen of the air, and become sulphuric aeid, which unites with the lime and makes sulphate of lime (plaster,) which form it must assume, before it is of nuch value. Having been used to purify gas made from coal, it contains a small quantity of ammonia, which adds to its value. It is considered a profitable manure in England, at the price there paid for it (forty cents a cartload), and, if of good quality, it may be worth more than that, especially for soils deficient in sulphuric acid or lime, or for such crops as are inucli benefited by plaster. Its price must, of course, be regulated somewhat by the price of lime, which constitutes a large proportion of its fertilizing parts. The offensire odor of this compound renders it a good protection 
against many insects, when used in its fresh state; but in this state it should be very cautiously applied.

The refuse liquor of gas works contains enough ammonia to make it a valuable manure. It should be filtered through earth or muck, which will retain its valuable parts, and will be enriched by them.

\section{SOAPERS' LEY AND BLEACHERS' LEY.}

The refuse ley of soap factories and bleaching establishments contains greater or less quantities of soluble silicates and alkalies (especially soda and potash,) and is a good addition to the tank of the compost heap, or it may be used directly as a liquid application to the soil, or, better, filtered as above described. The soaper's' ley, especially, will be found a good manure for lands on which grain lodges.

Much of the bennefit of this manure arises from the solnble silicates it contains, while its nitrogenous matter obtained from those parts of the fatty matters which cannot be converted into soap, and consequently remain in this solution, forms a valuable addition. Heaps of soil saturated with this liquid in autumn, and subjected to the freezings of winter, form an admirable manure for spring use.

\section{IRRIGATION.}

Irrigation, strictly speaking, should not be considered under the head of earthy manures alone, as it 
often supplies ammonia and other organic matters to the soil. Its elief valne, however, in most cases, must depend on the amount of mineral matter which it furnishes.

The word "irrigation" means simply the act of watering. In many districts water is in varions ways made to overflow the land, and is removed or withlield when necessary for the purposes of cultivation. All river and spring water contains some impurities, many of which are beneficial to vegetation. These are derived from the earth over, or throngh, which the water has passed. Ammonia also is absorbed by the water from the atmosphere. When water is made to cover the earth, especially if its rapid motion be arrested, much of this fertilizing matter settles, and is deposited on or absorbed by the soil. The water which sinks into the soil carries its impurities to be retained for the uses of plants. When, by the aid of under-drains, or the open texture of the land, the water passes through the soil, its impurities are arrested, and become arailable in regetable growth. It is, of course, impossible to say exactly what kind of mineral matter is supplied by the water of irrigation, as that depends on the kind of rock or soil from which the impurities are derived; but, whatever it may be, it is generally soluble and ready for immediate use by plants, and is distributed in the most uniform manner possible.

Water which has run orer the snrface of the earth contains both ammonia and mineral matter, while that which has arisen out of the earth, contains 
usually only mineral matter. The direct effect of the water of irrigation as a solvent and distributer of the mineral ingredients of the soil, constitutes one of its main benefits.

To deseribe the many modes of irrigation would be too long a task for our limited space. It may be applied in any way in which it is possible to cover the land with water, at stated times. Care is necessary, however, that it does not wash more fertilizing matter away from the soil than it deposits upon it, as would often be the case, if a strong current of watcr were run over it. Brooks may be dammed up, and thus made to cover a large quantity of land. In such a case the rapid current wonld be destroyed, and the fertilizing matter would settle; but, if the course of the brook were turned, so that it would run in a current over any part of the soil, it might carry away more than it deposited, and thus prove injurious. Small streams turned on to land, from the washing of roads, or from elevated springs, are good means of irrigation, and prodnce increased fertility, except where the soil is of such a character as to prevent the water from passing away, in which case it must first be under-drained.

Irrigation was one of the oldest sourees of fertility used by man, and still continues in great favor wherever its effects have been witnessed. In England and Scotland, much attention is now being paid to the question of liquid manure irrigation, and an attempt is being made to employ the vast discharges of the London sewers. For this purpose it is in con- 
templation to build an aqueduct forty miles long and nine feet in diameter for its distribution. In the experiments made with this manure during the summer of 1867 , fitty-three tons of Italian rye-grass were grown on a single acre, niue tons being grown in twenty-two days.

On the farm of the celebrated Mr. Mechi at Tiptree Hall, the system was, many years ago, adopted of eonverting all the manure of the stables into a liquid, and distributing it over the farm by means of uuder-ground pipes and movable hose. Mr. Mechi still continues the practice and considers it profitable.

This subject is mentioned in this connection, not as affording an example which ean be profitably followed here, so much as because it shows how much expense may be profitably applied to the distribution of manure in a liquid form.

\section{MIXING SOILs.}

The mixing of soils is often all that is necessary to render them fertile, and to improve their mechanical condition. For instance, soils deficient in potash, or any other constituent, may have that deficiency supplied, by mixing with them soil containing this constituent in excess.

It is very frequently the case, that such means of improvement are easily availed of. While these chemical effeets are being produced, there may be an equal improvement in the mechanical character of 
the soil. Thus stiff clay soils are rendered lighter, and more easily workable, by an admixture of sand, while light blowy sands are compacted, and made more retentive of manure, by a dressing of clay or of muck. Of course, this eannot be depended on as a sure means of chemical improvement, but in a majority of eases the land will be benefited by mixing with it soil of a different character. It is not always necessary to go to other locations to procure the earth to be applied, as the sub-soil is often very different from the surface soil, and simple deep plowing will suffice, in such cases, to produce the required admixture, by bringing up the earth from below to mingle it with that of a different character at the surface.

Until it is demonstrated that a large admixture of the sub-soil will not lessen the fertility of the surface (and in a large majority of cases it will not), it is safest to deepen the plowing inch by inch. This subject is worthy of the consideration of all farmers, for there are very few cases in which the arable surface will not be improved by the addition of matters contained in the sub-soil. Even the earth thrown from the bottom of deep ditches sometimes has an astonishing effect on the fertility of the soil, and it would be well to try the experiment of digging a deep pit, spreading the earth taken from it on the suiface of the land. If this is found to have a good effect, it will offer a ready means of improving the soil. 
In the foregoing remarks on the subject of mineral manures, I have endeavored to point ont such a course as would result in the "greatest good to the greatest number," and consequently, have neglected much which might discourage the farmer with the idea, that the whole system of scientific agriculture is too expensive for his adoption. Still, while I have confined my remarks to the more simple improrements on the present system of inanagement, I would say briefly, that no manuring can be strictly economical that is not based on a knowledge of the requirements of the soil and of the crops, and of the best means of supplying them, together with the most scrupulous care of every ounce of evaporating or soluble manure made on the farm, and a return of the earthy matters sold off in produce.

\section{CHAPTER $\boldsymbol{X}$.}

ATMOSPHERIC FERTILIZERS.

IT is not common to regard the gases in the atmosphere in the light of manures, but they are the most important manures we have, as they are the original source of more than nine-tenths of the entire production of our fields. Indeed, they are almost the only organic manure ever received by the uncultirated parts of the earth, as well as by a large portion of 
that which is occupied in the production of food for man.

If these gases were not manures; if there were no means by which they could be used by plants, the fertility of the soil would long since have ceased, and the earth would be unfertile. That this must be true, will be shown by a few moments' reflection on the facts stated in the first part of this book. The fertilizing gases in the atmosphere being composed of the constituents of decayed plants and animals, it is as necessary that they should be again returned to the form of organized matter, as it is that constituents taken from the soil should not be put out of existence.

\section{A MIONIA.}

The ammonia in the atmosphere probably cannot be appropriated by the leaves of plants, and must, therefore, enter the soil to be assimilated by roots. It reaches the soil in two ways. It is either arrested from the air circulating through the soil, or it is absorbed by rains in the atmosphere, and thus carried to the earth, where it is retained by its clay and carbon, for the uses of plants. In the soil, ammonia is the most important of all organic manures. In fact, the value of the organic parts of manure may be estimated, either by the amount of ammonia which they will yield, or by their power of absorbing ammonia from other sources.

The most important use of ammonia in the soil is 
to supply nitrogen to plants ; but it has other offices which are of consequence. It assists in some of tho chemical changes necessary to prepare the matters in the soil for assimilation, and gives to the water in which it is dissolved an increased power to dissolve mineral plant food.

Although, in the conrse of nature, the atmospheric fertilizers are largely supplied to the soil, withont the immediate attention of the farmer, it is not beyond his power to eause their absorption in still greater quantity. The means for doing this have been repeatedly giren in the preceding pages, but it may be well to name them again in this ehapter.

The condition of the soil is the main point to be considered. It must be such as to absorb and retain ammonia-to allow water to pass through it, and be discharged below the depth to which the roots of crops are searching for food-and to admit of a free cireulation of air.

The power of absorbing and retaining ammonia is not possessed by sand, but it is a prominent property of elay, chareoal, and some other matters named as absorbents. Hence, if the soil consist of pure sand, it will not make use of the ammonia brought to it from the atmosphere, but will allow it to evaporate immediately after a shower, or to be washed through it by rains. Soils in this condition requine additions of absorbent matters, to enable them to use the ammonia receired from the atmosphere. Soils already containing a sufficient amount of clay or charcoal, aro thus far prepared to receire benefit from this source. 
The next point is to cause the water of rains to pass through the soil. If it lies on the surface, or runs off without entering the soil, it is not probable that the fertilizing matters which it contains will all be abstraeted. Some of them will undoubtedly return to the atmosphere on the evaporation of the water; but, if the soil contains a sufficient supply of absorbents, and will allow all rain water to pass through it, the fertilizing gases will all be retained. They will be filtered out of the water, which will pass out of the drains almost pure. .

This subject will be more fully treated in Section IV., in connection with under-draining.

Besides the properties just described, the soil ought to possess the power of admitting a free circulation of air. To effect this, the soil should be well pulverized to a great depth. If, in addition to this, it be of such a character as to allow water to pass through it, it will facilitate such a circulation of air as is best calculated to give the greatest supply of ammonia.

\section{CARBONIC ACID.}

$\therefore$

Carbonic acid is received from the atmosphere, both by the leaves and by the roots of plants.

It is absorbed by the water in the soil, and greatly increases its power of dissolving earthy plant food. This use is one of very great importance, as it is equivalent to making the minerals themselves more soluble. Water dissolves earbonate of lime, etc., 
exactly in proportion to the amount of earbonic acid which it contains. We should, therefore, strive to have as much earbonic acid as possible in the water in the soil. One way, in which to effect this, is to admit to the soil the largest possible quantity of atmospheric air, which contains this gas.

The condition of soil necessary for this, is the same as is required for the deposit of anmonia by the same circulation of air.

\section{OXIGEN.}

Oxygen, though not taken up by plants as food in its pure form, may justly be classed among manures, if we consider its effects both chemical and mechanical in the soil.

1. By oxidizing or rusting some of the constituents of the soil, it prepares them for the uses of plants.

2. It unites with the protoxide of iron, and changes it to the peroxide.

3. If there are acids in the soil, which make it sour and unfertile, it may be opened to the circulation of the air, and the oxygen will prepare some of the mineral matters contained in the soil to unite with the acids and neutralize them.

4. Oxygen combines with the carbon of organic matters in the soil, and causes them to decay. The combination produces carbonic acid.

5. It undoubtedly affeets in some way the matter which is thrown out from the roots of plants. This, 
if allowed to accumulate, and remain unchanged, is supposed to be injurious to plants; but, probably, the oxygen and carbonic acid of the air in the soil change it to an inoffensive form, and even make it again useful to the plaut.

6. It may also improve the mechanical condition of the soil, as it causes its particles to crumble, thus making it finer; and it roughens the surfaces of particles, making them less likely to become too compact.

These properties of oxygen claim for it a high place among the atmospheric fertilizers.

WATER.

Water may be considered an atmospheric nanure, as its chief supply to vegetation is received from the air in the form of rain or dew. Its inany effects are already too well known to need further comment.

Supplying water to the soil by the deposit of dew will be considered in Section IV.

\section{CHAPTER XI.}

, RECAPITULATION.

Maxures have two distinct classes of action in the soil, namely, chemical and mechanical. 
Chemical manures are those which enter into the construction of plants, or produce such chemical effects on matters already contained in the soil as shall prepare them for use.

Mechanical manures are those which improve the mechanical condition of the soil, such as loosening stiff clays, compacting light sands, pulverizing large particles, etc. Many manures act both chemically and mechanically.

Manures may be classified under three distinct heads, namely, Organic, mineral, and atmospleric.

Organic manures comprise all regetable and animal matters (except ashes) which are used to fertilize the soil. Tegetable manures supply carbonic acid, some ammonia, and eartly matter to plants. Animal manures supply the same substances and much more ammonia.

Ifineral manures comprise ashes, salt, phosphate of lime, plaster, etc. They supply plants witl earthy matter. Their usefulness depends in great degree on their solubility.

Many of the organic and mineral manures have the power of absorbing ammonia arising from the decomposition of animal manures, as well as that which is brought to the soil by rains-these are called $a b$ sorbents.

Atmospheric manures consist of ammonia, carbonic acid, oxygen and water. Their greatest usefulness requires the soil to allow the water of rains to pass through it, to admit of a free circulation of air among its particles, and to contain a sufficient 
amount of absorbent matter to arrest and retain all ammonia and carbonic acid presented to it.

Manures should be applied to the soil with due regard to its requirements.

Ammonia and carbon are always useful, but mineral manures become mere dirt when applied to soils already containing them in abundance.

Organic manures must be protected against the escape of their ammonia, and especially against the leaching out of their soluble parts. One cord of stable manure properly preserved, is worth ten cords which have lost all of their ammonia by evaporation, and their soluble parts by leaching - as is the case with much of the manure kept exposed in open barn-yards.

Atmospheric manures cost nothing, and are of great value when properly employed. In consequenee of this, the soil which is enabled to make the largest appropriation of the atmospheric fertilizers, is worth many times as much as that which allows them to eseape.

In fact, it may be considered to be the object of all cultication, to use the advantages which the soil and manures offer for the purpose of eonsolidating and giving a useful form to the carbonic acid, ammonia and water, which are freely offered to all seekers.

Liebig says :- " A certain mass of gold and silver circulates in the world, and the art of becoming rich consists in knowing the way to divert from the main stream an additional brook to-one's own house. In like manner there circulates, in the air 
and in the soil, a relatively inexhaustible quantity of the food of plants; and the art of the farmer consists in knowing and using the means of rendering this food arailable for his crops. The more he is able to divert from the moving stream (the air) to the immorable promoter of his production (the soil of his fields), the more will the sum of his wealth and his products increase."

$8 *$ 




\section{SECTION FOURTH.}

\section{MECHANICAL CULTIVATION.}

\section{CHAPTER I.}

THE MEOHANICAL CHARACTER OF SOIL 8 .

THE mechanical character of the soil has been sufticiently explained in the preceding remarks, and the learner knows that it has many offices to perform aside from the feeding of plants.

1. It admits the roots of plants, and holds them in their position.

2. By a sponge-like aetion, it holds water for the uses of the plant.

3. It absorbs moisture from the atmosphere to supply the demands of the plants.

4. It absorbs heat from the sun's rays to assist in the processes of growth.

4. It admits air to circulate among roots, and snpply them with a part of their food, while the oxygen 
of that air renders available the minerals of the soil ; and its carbonic acid, being absorbed by the water in the soil, gives it the potrer of dissolving and supplying to roots more earthy matter than would be dissolved by purer water.

All of these actions the soil must be capable of performing, before it can be in its highest state of fertility. There are comparatively few soils now in this condition, but there are also few which could not be profitably rendered so, by a judicious application of the various modes of cultivation.

The three great objects to be accomplished are:-

1. To adopt such a system of drainage as will cause as much as possible of the water of rains to pass through the soil, instead of evaporating from the surface.

2. To pulverize the soil to a considerable depth.

3. To darken its color, and to render it capable of absorbing atmospheric fertilizers.

The means used to secure these effects are underdraining, sub-soil and surface-plowing, digging, applying muck, etc.

$\therefore$

CHAPTER II.

UNDER-DRAINING.

ÁcL soils which are cultivated should be thoroughly underdrained, either naturally or artificially. 
All lands whieh are made wet by springs or through which the water of rains does not readily settle away, must be drained artificially before they can be eultivated to the best advantage.

The advantages of under-drains over open-drains are very great.

When open drains are nser, much water passes into them immediately from the surface, and carries with it fertilizing parts of the soil, while their beds are often puddled by the running water and baked by the heat of the sun, so that they become water tight, and do not admit water from the lower parts of the soil.

The sides of these drains are often eorered with weeds, which spread their seeds throughout the whole field. Open drains are not only a great obstruction to the proper cultivation of the land, but they cause much waste of room, as we can rarely plow nearer than within six or eight feet of them.

There are none of these objections to the nse of under-drains, as these are completely covered, and do not at all interfere with the cultivation of the surface.

Under-drains may be made with brush, stones, or tiles. Brush is a very poor material, and its use is hardly to be recommended, except when a better material cannot be afforded. Small stones are better, and if these be placed in the bottom of the trenches, to a depth of eight or ten inehes, and covered with a little litter, having the earth packed well down on them, they make very good drains. But 
they are very much more costly than tile drains, and are not so permanent.

\section{TILE DRAINING.}

The best under-drains are those made with tiles, or burnt clay pipes. The first form of these used was that called the horse-shoe tile, which has the form of an areh, leaving the unprotected ground for the water to flow over; this was superseded by the round pipe, and the sole tile.

"Experienee in both public and private works in this country, and the cumulative testimony of English and French engineers, have demonstrated that the only tile which it is economical to use, is the best that can be found, and that the best,-much the best,- - thus far invented, is the pipe, or round tile, and collar;

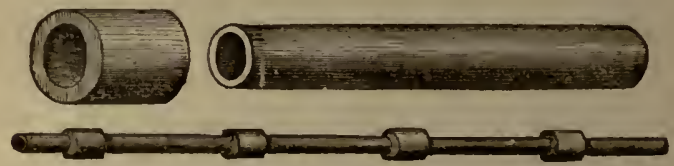

Fra. 3.-Round Tile and Collar.

and these are unhesitatingly recommended for use in all cases. Round tiles of small sizes should not be laid without collars, as the ability to use these constitutes their chief advantage; holding them perfectly in place, preventing the rattling in of loose dirt in laying, and giving twice the space for the entranee of water at the joints. A chief advantage of the largêr sizes is, that they may be laid on any side and thus made to fit closely. The usual sizes of these 
tiles are $1 \frac{1}{4}$ inches, $2 \frac{1}{4}$ inches, and $3 \frac{1}{2}$ inches in intc. rior diameter. Sections of the $2 \frac{1}{4}$ inch make collars for the $1 \frac{1}{4}$ inch, and sections of the $3 \frac{1}{2}$ inch make collars for the $2 \frac{1}{4}$ inch. The $3 \frac{1}{2}$ inch does not need collars, as it is easily secured in place, and is only nsed when the flow of water wonld be sufficient to wash ont the slight quantity of foreign matters that might enter at the joints." *

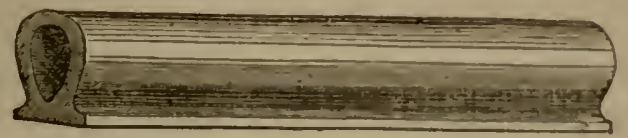

FIr, 4-Sole Tilo.

This tile is made (like the horse-shoe and pipe tile) of common brick clay, and is burned the same as bricks. It is about one half or three quarters of an inch thick. The orifice through which the water passes is egg-shaped, having its smallest curve at the bottom. This shape is the one most easily kept elear, as any particles of dirt which get into the drain must fall immediately to the point where even the smallest stream of water runs, and are thins remored. An orifice of about two inches rise is suffieient for the smaller drains, while the main drains require larger tiles.

These tiles are so laid that their ends will tonch each other, on the bottoms of the trenches, and are kept in position by having the earth tightly packed

* Draining for Profit and Draining for Health, by G. E. Wraring, Jr., page 81. 
around them. Care must be taken that no space is left between the ends of the tiles, as dirt would be liable to get in and choke the drain. This may be best prevented by the use of collars; but if sole tiles are used, as collar's cannot be fitted to them, it is well to cover the top of the joint with a very small rope of twisted grass, secured by a stone or lump of clay on each end, or to lay on the joint a saddle of bent tin, zinc, or galranized iron, which may be obtained at little cost from a tinsmith, cut from pieces in the waste-heap.

The ditches for tile draining may be narrowed in, at the bottom, to a width barely sufficient for the workman's foot. In filling-in, atter the tile is laid, care should be taken that no stones large enongh to break the tile be allowed to fall upon them. After the tiles are covered to a depth of a foot or eighteen inches, the tilling should be trodden, or pounded, fimly down, so as to fit closely around the tiles, and leave no space for water to circulate about them.

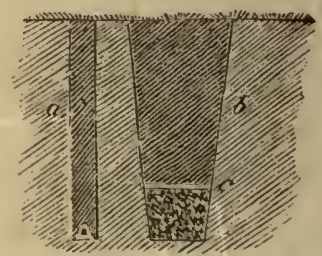

Fid. 5.

Tile drains are made with much less labor than the stone drains, as they require less digging, while the breaking up of the stone for the stone drain will be usually more expensive than the tiles. Drains $a$-Tile drain trench.

$b$-Stone drain trench.

c-Sod laid on the stone. made with large stones are not ncarly so good as with sinall ones, because they are more liable to be choked up by animals working in them. 
CLLTIVATION.

\section{CHAPTER III.}

ADVANTAGES OF UNDER-DRAINIXG.

THE advantages of under-draining are many and important.

1. It greatly lessens the injurions effects of drought.

2. It admits an increased supply of atmosplicric fertilizers.

3. It warms the lower portions of the soil.

4. It hastens the decomposition of roots and other organie matter.

5. It accelerates the disintegration of the minerals in the soil.

6. It causes a more eren distribntion of nutritious matter's among those parts of soil traversed by roots.

7. It improres the mechanieal texture of the soil.

8 . It tends to prevent grasses from "running ont."

9. It enables us to deepen the surtice soil.

By remoring excess of water-

10. It reuders soils earlier in the spring.

11. It greatly lessens the throwing out of grain in winter.

12. It allows us to work sooner after rains.

13. It keeps off the effects of cold weather longer in the fall.

14. It prevents the formation of acetic and other organic acids, which induce the growth of sorrel and similar weeds.

15. It hastens the decay of regetable matter, and 
the finer comminution of the earthy parts of the soil.

16. It prevents, in a great measure, the evaporation of water, and the consequent cooling of the soil.

17. It admits fresl quantities of water from rains, etc., which are always more or less imbued with the fertilizing gases of the atmosphere, to be deposited among the absorbent parts of soil, and given up to the demands of plants.

18. It prevents the formation of so hard a crust on the surface of the soil as is customary on heary lands.

1. Under-draining lessens the effect of drought, becanse it gives a better circulation of air in the soil , (it does so by making it more open). There is always the same anount of water in and about the surface of the earth. In winter there is more in the soil than in summer, while in summer, that which has been driea out of the soil exists in the atmosphere in the form of a vapor. It is held in the vapory form by heat, which acts as braces to keep it distended. When vapor comes in contact with substanees sufficiently colder than itself, it gives up its heatthus losing its braces-contracts, and becomes liquid water.

This may be observed in hundreds of common operations.

It is well known that a cold pitcher in summer 
robs the vapor in the atmosphere of its leat, anil causes it to be deposited on its own surface. It looks as though the pitcher were suceating, but the water all comes from the atmosphere, not, of course, through the sides of the pitcher.

If we breathe on a knife-blade, it condenses in the same manner the moisture of the breath, and becomes covered with a film of water.

Stone houses are damp in summer, because the inner surfaces of the walls, being cooler than the atmosphere, cause its moisture to be deposited in the manner described. By leaving a space, however, between the walls and the plaster, this moisture is prevented from being troublesome, and if the space is closed against the circulation of air containing moisture there will be no vapor brought in contact with the cool surface of the wall, and therefore no deposit of inoisture.

Nearly every night in the summer season, the cold earth receives moisture from the atmosphere in the form of dew.

A cabbage, which at night is very cold, condenses water to the amount of a gill or more.

The same operation takes place in the soil. When the air is allowed to circulate among its lower and cooler particles, they receive moisture from the sume process of condensation. Therefore, when, by the aid of under-drains, the lower soil becomes sufficiently open to admit of a circulation of air, the deposit of atmospheric moisture will keep the soil supplied with water at a point easily accessible to the roots of plants. 
If we wish to satisfy ourselves that this is practically correct, we have only to prepare two boxes of finely pulverized soil-one, five or six inches deep, and the other fiftecn or twenty inches deep-and place them in the sun at mid-day in snmmer. The thinner soil will be completely dried, while the deeper one, though it may have been dried in an oven at first, will soon accumulate a large amount of water on those particles which, being lower and more sheltered from the sun's heat than the particles of the thin soil, are made cooler.

With an open condition of subsoil, then, such as may be secured by under-draining, we fortify ourselves against drought.

2. Under-draining admits an increased supply of atmospheric fertilizers, because it secures a change of air in the soil. This change is produced when ever the soil becomes filled with water, and then dried; when the air above the earth is in rapid motion, and when the comparative temperature of the upper and lower soils changes. It causes new quantities of the ammonia and earbonic acid which it contains to be presented to the absorbent parts of the soil.

3. Under-draining warms the lower parts of the soil, because the deposit of moisture (1) is necessarily aceompanied by an abstraction of heat from the atmospheric rapor, and because heat is withdrawn from the whole amount of air circulating through the cooler soil.

When rain falls on the parehed surface soil, it robs 
it of a portion of its heat, which is earried down to equalize the temperature for the whole deptlo. The heat of the rain-water itself is given up to the scil, leaving the water from one to ten degrees corler, when it passes ont of the drains, than when received by the earth.

This heating of the lower soil of conrse renders it more favorable to regetation.

4. Under-draining hastens the decomposition of roots and other organic matters in the swil, by admitting inereased quantities of air, thus supplying oxygen, which is as essential in decay as it is in connbustion. It also allows the resultant gases of decomposition to pass away, leaving the air around the deeaying substances in a condition to continue the process.

This organic deeay, besides its other benefits, produees an amount of heat perfectly pereeptible to the smaller roots of plants, though not so to nis.

5. Draining accelerates the disintegrution of the minerals in the soil, by admitting water and oxygen to keep up the process. This disintegration is necessary to fertility, becanse the roots of plants can feed only on matters dissolved from surfuces; and the more finely we pulverize the soil, the more surface we expose. For instance, the interiol of a stone ean furnish no food for plants; while, if it were finely erushed, it might make a fertile soil.

Anything tending to open the soil to the air facilitates the disintegration of its particles, and thereby increases its fertility. 
6. Draining causes a more even distribution of nutritious matters among those parts of soil traversed by roots, because it increases the ease with which water travels about, descending by its own weight, moving sideways by a desire to find its level, or carried upward by attraction to supply the evaporation at the surface. By this continued motion of the water, soluble matter from one part of the soil may be carried to adjacent parts ; and another constituent from this latter position may be carried back to the former. Thus the food of vegetables is evenly distributed through the soil. As soon as one particle is fully supplied with any element of plant nutrition, further amounts brought by water are carried to the next particle that can reeeive it-and so on, until the supply of soluble material is exhausted. This food is ready for absorption at any point where it is needed, while the more open character of the soil enables roots to occupy larger portions, making a more even drain on the whole, and preventing the undue imporerishment of any part.

7. Under-drains improve the mechanical texture of the sail; because, by the decomposition of its parts, as previonsly described ( 4 and 5 ), it is rendered of a charaeter to be more easily worked; while smooth round particles, which have a tendeney to pack, are roughened by the oxidation of their surfaces, and move less easily among each other.

8. By under-draining, grasses are prevented from running out. The grasses of meadows usnally consist of tillering plants, which reproduce themselves 
in sprouts from the upper parts of their roots, or from the joints of the roots. These sprouts become independent plants, and eontinue to tiller (thus keeping the land supplied with a full growth), until the roots of the stools (or clumps of tillers), come in contact with an uncongenial part of the suil, when the tillering eeases; the stools become extinct on the death of their plants, and the grasses rum out.

The open and healthy condition of soil prodneed by draining prevents the tillering from being stopped so long as the fertility of the soil lasts, and thus keeps up a full growth of grass until the nutriment of the soil is exhansted.

9. Draining enables us to deepen the surface-soil, because the admission of air and the decay of roots, (which descend much deeper in drained than in undrained land,) render the condition of the sulb-soil such, that it may be bronght up and mixed with the surface-soil, without injuring its quality.

The second class of advantages of under-draining, arising in the remoral of the excess of water in the soil, are quite as important as those just described.

10. Soils are, thereby, rendered carlier in sming, because the water, which rendered them cold, heary, and untillable, is earlier remored, leaving them enrlier in a growing condition.

11. The throwing out of grain in winter is lessened, because the water falling on the earth is immediately removed instead of remaining to throw up 
the soil by freezing, as it always does, from the upright position taken by the particles of ice.

12. We are enabled to work sooner after rains, because the water descends, and is inmediately removed, instead of lying to be taken off by the slow process of evaporation, and sinking through a lieavy soil.

13. The effects of cold weather are kept off longer in the fall, by the removal of the excess of water which would produce an unfertile condition on the first appearance of cold weather.

The drains also, from causes already named (3), keep the soil warmer than before being drained, thus actually lengthening the season, by making the soil warm enough for vegetable growth earlier in spring, and later in autumn.

14. Lands are prevented from becoming sour by the formation of acetic acid, etc., because these acids are produced in the soil only when organic matter decomposes in contact with an excessive quantity of water. If the water is removed, the decomposition of the organic matter assumes a healthy form, while the acids already produced are nentralized by atmospheric influences, and the soil is restored to a condition in which it is fitted for the growth of the more valuable plants.

15. The decay of roots, etc., is allowed to proceed, because the preservative influence of too much water is removed. Wood, leaves, or other vegetable matter kept continually under water, will last for ages; while, if exposed to the action of the weather, as in under-drained soils, they soon decay. 
The presence of too much water, by excluding the oxygen of the air, prevents the comminution of mincral matters necessary to fertility.

16. The evaporation of water, and the consequent cooting of the soil, is in a great measure prevented by draining the water out at the bottom of the suil, instead of leaving it to be dried off from the surface.

When water assumes the gaseous (or vapory) form, it occupies nearly 2000 times the space it ocenpierl as a liquid, and as the vapor is of the same temperature as the liquid, it follows that it contains rastly more heat. A large part of this heat is derived from surrounding substances. When water is sprinkled on the floor, it cools the room; hecause, as it becornes a rapor, it takes heat from the room. The reason why vapor does not feel hotter than liquicl water is, that, its heat is diffused through the larger mass, so that a cubic inch of rapor, into which we place the bulb of a thermometer, contains no more heat than a cubic inch of water. The principle is the same in some other cases. $\Lambda$ sponge containing a table spoonful of water is just as wet as one twice as large containing two spoonfuls.

If a wet cloth be placed on the head, and the evaporation of its water assisted by fanning, the head becomes cooler-a portion of its heat being taken to sustain the vapory condition of the water.

The same principle holds true with the soil. When the evaporation of water is rapidly going on, by the assistance of the sun, wind, etc., a largo 
quantity of heat is abstracted, and the soil becomes cold.

This cooling of the soil by the eraporation of water, is of very great injury to its power of producing erops, and the fact that under-drains lessen it, is one of the best arguments in favor of their use. Some idea may, perhaps, be formed of the amount of heat taken from the soil in this way, from the fact that, in midsummer, twenty-five hogsheads of water may be eraporated from a single acre in twelve hours.

17. When not saturated with water the soil admits the water of rains, etc., which bring with them fertilizing gases from the atmosphere, to be deposited among the absorbent parts of the soil, and giren up for the necessities of the plant. When this rain falls on lands already saturated, it cannot enter the soil, but must run off from the surface, or be removed by evaporation, either of which is injurious. The first, because fertilizing matter is washed away. The second, beeause the soil is deprived of necessary lieat.

18. The formation of crust on the surface of the soil is dne to the evaporation of the water of the soil. It arises partly from the fact that the water in the soil is saturated with mineral substances, which it leaves at its point of eraporation at the surface. This soluble matter often forms a very hard crist, which is a complete shield to prevent the admission of air with its ameliorating effeets, and shonld, as fir as possible, be avoided. Under-draining is the best 
means of doing this, as it is the best means of lessening the evaporation, and of preventing the puddling of the clay in the suil.

The foregoing are some of the more important reasons why under-draining is always heneficial. Thorough experiments have amply prover the truth of the theory.

"Land which requires draining is that which, at some time during the year, (either from an acemmulation of the rains which fall upon it, fiom the lateral flow or soakage from adjoining land, from springs which open within it, or from a combination of two or all of these sonrces,) becomes filled with water that does not readily find a natural ontlet, but remains until remored by evaporation. Every considerable addition to its water wells up, and soaks its very surface; and that which is added alter it is already brim-full, must flow off over the surface, or lie in puddles upon it. Evaporation is a slow process, and it becomes more and more slow as the level of the water recedes from the surface, and is sheltered by the overlying earth from the action of sun and wind. Therefore, at least during the periods of spring and fall preparation of the land, during the early growth of plants, and often even in miclsummer, the water-tuble,-the top of the water of saturation,-is within a few inches of the surface, preventing the natural deseent of roots, and, by reason of the small space to receive fresh rains, callsing an interruption of work for some days after each storm. 
"If such land is properly furnished with tile drains, (having a clear and suffieient outfall, offering sufficient means of entrance to the water which reaches them, and carrying it, by a uniform or increasing deseent, to the outlet,) its water will be removed to nearly, or quite, the level of the floor of the drains, and its water-table will be at the distance of some feet from the surfuce, leaving the spaces between the particles of all the soil above it filled with air instead of water. The water below the drains stands at a level, like any other water that is dammed up. Rain-water falling upon the soil, will deseend by its own weight to this level, and the water will rise into the drains, as it would flow over a dam, until the proper level is again obtained. Spring-water entering from below, and water oozing from the adjoining land, will be remored in like manner, and the usual condition of the soil, above the water-table, will be that which is best adapted to the growth of useful plants.

"In the heaviest storms, some water will flow over the surface of even the dryest beach sand; but in a well-drained soil the water of ordinary rains will be at once absorbed, will slowly descend toward the water-able, and will be removed by the drains so rapidly, even in heavy clays, as to leave the ground fit for cultivation, and in a condition for steady growth, within a short time after the rain ceases. It has been estimated that a drained soil has room between its particles for about one quarter of its bulk of water, that is, four inches of drained soil con- 
tains free space enoughl to receive a rain-fall one inch in depth, and, by the same token, four feet of drained soil can receire twelve inches of rain,more than is known to have ever fallen in twentyfour hours since the deluge, and more than one quirter of the arnual rain-fall in the United States." *

Of the precise profits of under-draining this is not the place to speak: many of the agrieultural papers contain numerous accounts of its success. It may be well to remark here, that many English fumers give it, as their experience, that under-drains on heary elay lands in ordinary eultivation, pay for themselves every three years, or that they produce as perpetual profit of $33 \frac{1}{3}$ per cent., on their original cost. This is not the opinion of theorists and book farmers. It is the conviction of practical men, who know, from experience, that under-drains are beneficial.

The best evidence of the utility of under-draining is the position, with regard to it, which has been taken by the English national government, which affords much protection to the agricultural interests of the people, - a protection which in this country is unwisely and unjustly withheld.

In England, a very large sum from the public treasury has been appropriated as a fund for loans, on under-drains, which was lent to farmers for the purpose of under-draining their estates, the only security given being the increased value of the soil. The time allowed for payments was twenty years, * Draining for Profit and Health, p. 22. 
and only five per cent. interest is charged. By the influenee of this patronage, the actual wealth of the kingdom has been rapidly inereased, while the farmers themselves can raise their farms to the lighest fertility, without immediate investment for draining.

The best proof that the government has not acted injudiciously in this matter is, that prirate capitalists employ their money in the same mamer, and loans on under-drains are considered a rery safe investment.

One very important, though not strictly agricultural, effect of thorough drainage is its removal of certain loeal diseases, peeuliar to the vicinity of marshy or low moist soils. The health-reports in several places in England, show that where fever and ague was once common, it las almost entirely disappeared since the general use of under-drains in those localities.

\section{$\therefore \quad$ CHÁPter IV.}

SUB-SOIL PLOWING.

THE sub-soil plow is an implement differing in figure from the surface plow. It does not turn a furrow, but merely runs through the sub-soil like a moleloosening and making it finer by lifting, but allowing it to fall back and occupy its former place. It 
usually follows the surface plow, entering the suil to the depth of from eight to fifteen inches below the bottom of the surface furrow.

The best pattern now made (the steel sub-soil plow) is represented in the following figure.

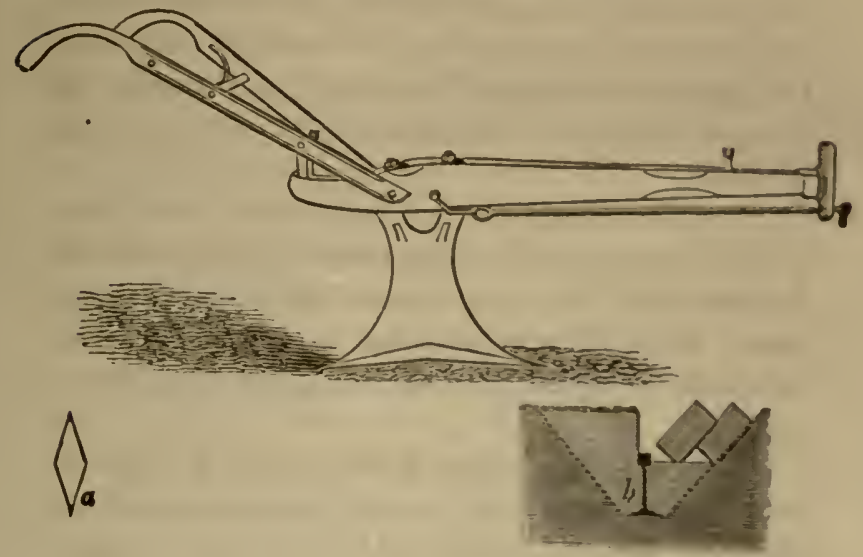

Fig. 6. - Wrought Iron and Steel Sub-soil Plow.

The sub-soil plows first made raised the whole soil about eight inches, and required very great power in their use, often six or eight oxen. The implement shown in the fignre, raising the soil but slightly, may be worked with much less power, and produces equally good results. It may be run to a good depth in most soils by a single yoke of oxen.

The motion of any part of the soil which is effected by this sub-soil plow is rery slight, but it is exerted thronghout the whole mass of the soil above the 
plow and for a considerable distance sideways toward the surface. If the land is too wet, this motion will be injurious rather than beneficial, but if it is dry enongh to erumble, it will be very much loosened. If we hold in the hand a ball of dry clay, and press it hard enough to produce the least motion among its particles, the whole mass becomes pulverized. On the same principle, the sub-soil plow renders the compact lower soil sufficiently fine for the entrance of roots.

Notwithstanding its great benefits on land, which is sufficiently dry, sub-soiling cannot be recommended for wet lands; for, in such case, the rains of a single season would often be sufficient to entirely overcome its effects by packing the sub-soil down to its former hardness.

On lands not overcharged with water, it is productive of the best results, it being often sufficient to turn the balance between a gaining and a losing business in farming.

It inereases nearly every effeet of under-draining; especially does it overcome drought, by loosening the soil, and admitting air to eirculate among the particles of the sub-soil, and deposit its moisture, on the principle described in the chapter on underdraining.

It deepens the surface-soil, becausc it admits roots into the sub-soil where they decay and leave carbon, while the circnlation of air so affects the mineral parts, that they become of a fertile character. As a majority of roots decay in the surface-soil, they 
there deposit mueh mineral matter obtained from the sub-soil, and thus render it richer.

The retention of atmospheric manures is more fully insured by the better exposure of the clayey portions of the soil.

The sub-soil often contains matters which are deficient in the surface-soil. By the use of the sub-soil plow, they are rendered available.

Sub-soiling is similar to under-draining in continuing the tillering of grasses.

When the sub-soil is a thin layer of clay on a sandy bed (as in many parts of the country), the sub-suil plow, by passing through it, opens a passage for water, and often affords a sufficient drainage.

If plants will grow better on a soil six inches deep than on one of three inches, there is no reason why they should not be benefited in proportion, by disturbing the soil to the whole depth to which roots will travel-even to a depth of two feet. The minute rootlets of corn and most other plants will, if allowed by eultivation, oceupy the soil to a greater depth than this, having a fibre in nearly every cubic inch of the soil for the whole distance. There are very few cultivated plants whose roots would not travel to a depth of thirty inches or more. Eren the onion sends its roots to the depth of eighteen inches when the soil is well cultivated.

The object of loosening the soil is to admit roots to a sufficient depth to hold the plant in its position, -to obtain the nutriment necessary to its growtl, to receive moisture from the lower portions of the 
soil,-and, if it be a bulb, tuber, or tap, to assume the form requisite for its largest development.

It must be evident that roots, penetrating the soil to a depth of two feet, anclior the plant with greater stability than those which are spread more thinly near the surface.

The roots of plants traversing the soil to such great distances, and being located in nearly every part, absorb mineral and other food, in solution in water, only through the spongioles at their ends. Consequently, by having these ends in every part of the soil, it is all bronght under contribution, and the amount supplied is greater, while the demand on any particular part may be less than when the whole requirements of plants have to be supplied from a depth of a few inches.

The ability of roots to assume a natural shape in the soil, and grow to their largest size, must depend on the condition of the soil. If it is finely pulverized to the whole deptlı to which they ought to go, they will be fully developed; while, if the soil be too hard for penetration, they will be deformed or small. Thus a parsnip may grow to the length of two and a half feet, and be of perfect slape, while, if it meet in its course, at a depth of eight or ten inches, a cold, hurd sub-soil, its growth must be arrested, or its form injured.

Roots are turned aside by a hard or wet sub-soil, as they would be if receired by the surface of a plate of glass.

Add to this the fact that cold, impenetrable sub- 
soils are chemically uneongenial to regetation, and we have sufticient evidence of the importance, and in many eases the absolute necessity of sub-soiling and under-draining.

It is unnecessary to urge the fact that a garlen soil of two feet is more productive than a ficld soil of six inches; and it is certain that proper attention to these two modes of cultivation will in a majority of eases make a garden of the field-more than doubling its value in ease of working, increased produce, certain seenrity against drought, and more eren distribution of the demands on the soil-while the outlay will be largely repaid by an immediate increase of crops.

The sub-soil will be much improved in its character the first year, and a continual advancement renders it in time equal to the original surface-soil, and extending to a depth of two feet or more.

The sub-soil plow has come into very general use. The implement has ceased to be a curiosity; and the man who now objects to its use, may be classed with hin who shells his corn on a shovel over a half-bushel, instead of employing an improved machine, which will enable him to do more in a day than he can do in the "good old way" in a week.

In no case will the use of the sub-soil plow be found anything but satisfactory, except in occasional instances where there is some chemieal difficulty in the sub-soil, which will be overcome by a year or two of exposure-and even such cases are extremely rare. As was before stated, its use on wet lands is not 
advisable until they hare been under-drained, as excess of water prevents its effects from being permanent.

\section{CHAPTER V.}

PLOWING AND OTHER PROCESSES FOR PULVERIZING THE SOIL.

The advantages of pulverizing the soil, and the reasons why it is necessary, have been sufficiently explained to need no further remark. Few farmers, when they plow, dig, or harrow, are enabled to give substantial reasons for the operation. If they will reflect on what has been said in the preeeding ehapters, concerning the supply of mineral food to the plant by the soil, and the effect of air and moisture about the roots, they will find more satisfaction in their labor.

\section{PLOWING.}

The kind of plow used in cultivating the surfacesoil, must be decided by the kind of soil. This question the practical, observing farmer will be able to solve.

As a general rule, it may be stated that the plow which runs the deepest, with the same amount of 
force, is the best, but this rule is not without its exceptions.

The advantages of deep plowing cannot be too strongly urged.

The statement that the deeper and the finer the soil is rendered, the more productive it will become, is in every respect true, and no single instance will contradict it.

It must not be inferred from this, that we would advise a farmer, who has always plowed his soil to the depth of only six inches, to double the depth at once. Such a practice in some soils would be highly injurious, as it would completely bury the more fertile and better cultivated soil, and bring to the top one which contains no organic matter, and has never been subject to atmospheric influences. This would, perhaps, be so little fitted for vegetation that it would searcely sustain plants until their roots could reach the more fertile parts below. Such treatment of the soil (turning it upside down) is excellent in garden culture, where the great amount of manures applied is sufficient to overeome the temporary barremness of the soil, but it is not to be recommended for all field eultivation, where mueh less manure is employed.

The course to be pursued in sueh eases is to plow a little deeper each year. By this means the soil may be gradually deepened to any desired extent. The amount of uneongenial soil which will thus he brought up, is slight, and will not interfere at all with the fertility of the soil, while the elerated por- 
tion will become, in a single year, so altered by exposure, that it will equal the rest of the soil in fertility.

Often where lime has been used in excess, it has sunk to the sub-soil, where it remains inactive. A slight deepening of the surface plowing would mix this lime with the surface-soil, and render it again useful.

When the soil is light and sandy, resting on a heavy clay sub-soil, or clay on sand, the bringing up of the mass from below will improve the textme of the upper parts.

As an instance of the success of deep plowing, we eall to mind the case of a farmer in New Jersey, who had a field which had yielded about twenty-five bushels of corn per acre. It had been cultivated at ordinary depths. After laying it out in eight-step lands ( 24 feet, ) he plowed it at all depths from five to ten inches on the different lands, and sowed oats evenly over the whole field. The crop on the five inch soil was very poor, on the six inch rather better, on the seven inch better still, and on the ten inch soil it was as fine as ever grew in New Jersey; it had stiff straw and broad leaves, while the grain was also much better than on the remainder of the field.

There is an old aneedote of a man who died, leaving his sons with the information that he had buried a pot of gold for them, somewhere on the farm. They commenced digging for the gold, and dug over the whole farm to a great depth without finding the 
gold. The digging, however, so enriched the suil that they were fully compensated for their disappointment, and becane wealthy from the increased produce of their farm.

Farmers will find, on experiment, that they have gold buried in their soil, if they will but dig deep enongh to obtain it. The law gives a man the uwnership of the soil for an indefinite distance from the surfice, but few seem to realize that there is another farm below the one they are cultirating, which is quite as valuable as the one on the surface, if it were but properly worked.

Fall plowing, especially for heavy lands, is the best means of securing the action of the frosts of winter to pulverize the soil. If it be a stiff elay, it will be well to throw the up-soil in high ridges (ly ridging and back-furrowing,) so as to expose the largest possible amount of surftee to the freezing and thawing of winter. This, with the rotting of the sod, (which is thus made ready for the feeding of plants,) makes the effects of fall plowing almost unirersally beneficial. The earlier the plowing is done, the more thoroughly the sod is rotted and prepared for the nutrition of the erop of the next year.

The great improvement of the age in the mechanieal branch of agriculture, has been made in England, during the past ten or twelve years, in the application of the steam-engine to the work of cultivating the soil. It would be beyond the scope of a simple elementary book like this to enter fully into a description of the machinery by which this work is 
done, and the method of its operation; but it is wortlyy of remark, that there are now in use in England about 500 sets of the apparatus, and that the system has been in successtul operation there for about a dozen years. A single engine (of 14 horse power) moves to the field on its own wheels, carrying the tackle with it, and plows an acre an hour with ease, or draws a deep cultivator through from three to five acres in an hour. The engine stands on one headland, and a pulley-wheel on the other, an endless steel wire rope passes around a windlass under the engine, and around the pulley opposite. The gang of plows, or the wide cultivator, is drawn baek and forth between the two.

\section{THE HARROW AND COLTIVATOR.}

The harrow, an implement largely used in all parts of the world, to pulverize the soil, and break clods, has beeome so firmly rooted in the affections of farmers, that it must be a very long time before they can be convinced that it is not the best implement for the use to which it is devoted. It is true that it pulverizes the soil for a depth of two or three inches, and thus much improves its appearance, benefiting it, without doubt, for the earliest stages of the growth of plants. Its action, however, is very defective, because, from the wedge shape of its teeth, it continually acts to pack the soil; thus-although favorable for the germination of the seed-it is not calculated to benefit the plant during the later stages 
of its growth, when the roots require the soil to be pulverized to a considerable depth.

The cultivator may be considered an improved harrow, the principal difference between them being, that while the teeth of the harrow are pointed at the lower end, those of the cultirator are shaped like a small double plow, being large at the bottom and growing smaller toward the top. They lift the earth up, instead of pressing it downward, thus loosening instead of compacting the soil.

Many styles of eultivators are now sold at agricultural warehouses. A very good one, for field use, may be made by substituting the cultivator teeth for the spikes in an old harrow frame.

\section{CHAPTER VI.}

ROLLING, MULCIING, WEEDING, ETO.

\section{ROLLING.}

RoLLna the soil with a large roller, drawn by a team, is in many instances a good accessory to cultivation. By its means, the following results are obtained :-

1. The soil at the surface is pulverized without the compacting of the lower parts, the area of contact being large. 
2. The stones on the land are pressed down so as to be out of the way of the mowing machine.

3. The soil is compacted around seeds after sowing in such a manner as to exclude light and to touch them in every part, both of which are of essential advantage in their germination, and assist in giving them a good start.

4. When the soil is smoothed in this manner, there is less surface exposed for the evaporation of water with its cooling effect.

5. Light sandy lands, by being rolled in the fall, are rendered more compact, and the loosening effects of frequent freezing and thawing are lessened.

6. The most important use of the roller is in compacting the earth about the roots of grass and grain crops early in the spring. The freezing and thawing of winter leave them usually partly uncovered, or surrounded by air spaces. Their best growtl requires that these roots be closely pressed by the earth, -and this pressure is given by the roller better than in any other way.

If well under-drained, a large majority of soils would doubtless be benefited by a judicions use of the roller.*

\section{MULCHING.}

Mulching consists in covering the soil with salt hay, litter, seaweed, leaves, spent tanbark, chips, or other refuse matter.

Every farmer minst have noticed that, if a board or

* Field rollers should be made in sections, for ease of turning. 
rail, or an old brush-heap, be removed in spring from soil where grass is growing, the grass afterwarl grows in those places much larger and better that in other parts of the field.

This improvement arises from various causes.

1. The evaporation of water fiom the soil is prevented during drought by the shade afforded by the mulch; and it is therefore kept in better condition, as to moisture and temperature, than when evaporation goes on more freely. This condition is well calculated to advanco the chemical changes necessary to prepare the matters-both organic and mineral-in the soil for the use of plants.

2. A heary mulch breaks the force of rains, and prevents them from compacting the suil, as would be the result were no such precaution taken.

3. Mulching protects the surface-soil from free\%ing as readily as when exposed, and thus keep's it longer open for the admission of air and moisture. When unprotected, the soil early becomes frozen; and all water falling, instead of entering, as it should do, passes off over the surface.

5. The throwing out of winter grain is often prerented, because this is due to the frequent freezing: and thawing of the surface-soil.

6. When the wet surface-soil freezes, it is raised up. and the young plants growing in it are raised with it; when the frost is thawed out, the soil falls back to its original position, while parts of the crowns or roots of the crop remain raised. The next freeze takes hold of them lower down, and lifts them again; 
the next thaw leaves them higher than ever,- - until in spring, sometimes, the crown of a shoot of wheat will be standing several inches above the level of the soil. The use of a mulch prevents both the freezing and the thawing from being so frequent and active as they would be if no protection were used.

7. It also prevents the "baking" of the soil, or the formation of a crust.

Nursery-men often keep the soil about the roots of young trees mulched continually. One of the chief arguments for this treatment is, that it prevents the removal of the moisture from the soil and the consequent loss of heat. Also that it keeps up a full supply of water for the uses of the roots, because it keeps the surface of the soil cool, and causes a deposit of dew.

It has been suggested, and is undoubtedly true, that a mulch on the ground, by affording a good shelter for minute (microscopic) insects, causes them to accumulate in such quantities as to add (by their eggs, their excrement, and their dead bodies) to the fertilizing matter in the soil. How important this addition may be, we cannot of course know, but it is certain that mulching exercises grcater good effect than can reasonably be attributed, in the present state of our knowledge, to any or all of the above described actions.

It is the opinion of many, that at least one-half of the beneficial effect of seaweed, or coarse stable manure, when used as a top dressing, is due to its action as a mulch.

It is a good plan to sow oats very thinly over land intended for winter fallow, after the removal of crops, 
as they will grow a little before being killed by the frost, when they will fall down, thus affording a rery beneficial muleh to the soil.

When farmers spread coarse manure on their fields in the fall to be plowed under in the spring, they benefit the land by the mulehing, perhaps as much as by the addition of fertilizing matter, beeause they give it the protecting influence of the straw, ete.

It is an old and true saying that "snow is the poor man's manure." One reason why it is so beneficial is, that it acts as a most exeellent muleh. It contains no more ammonia than rain-water does; and, were it not for the fact that it protects the soil against loss of heat, and produces other benefits of mulching, it would have no more advantagenus effect. The severity of the winters at the North is largely compensated for by the long duration of snow.

It is well known that when there is but little snow in cold countries, wheat is very liable to be winter killed. An evenly spread mulch, and thorongh draining, will greatly prevent this.

This treatment is peenliarly applicable to the enltivation of flowers, both in pots and in beds out of doors. It is almost indispensable to the profitable production of strawberries, and many other garden erops, such as asparagus, rhubarb, etc. An excellent treatment for newly transplanted trees, is to put stones about their roots. A good mulching, by the use of leaves, eopying the action of nature in forests, has nearly as good an effect; for it is chiefly as a muleh that the stones are beneficial. 


\section{WEEDING.}

If a farmer were asked-what is the use of weeds ? he might make out quite a list of their benefits, among which might be some of the following:-

1. They shade tender plants, and in a measure serve as a muleh to the ground.

2. Some weeds, by their offensive odor, drive away many insects.

3. They may serve as a green crop to be plowed into the soil, and increase its organic matter.

4. They make us stir the soil, and thus inerease its fertility.

Still, while thinking out these excuses for weeds (all but the last of which are very feeble ones), he would see other and more urgent reasons why they should not be allowed to grow.

1. They oceupy the soil to the disadvantage of crops.

2. They exclude light and heat from cultivated plants, and thus interfere with their growth.

3. They take up mineral and other matters from the soil,'; and hold them during the growing season, thus depriving crops of their use.

It is not necessary to argue the injury done by weeds. Every farmer is well convinced that they should be destroyed, and the best means of aecomplishing this is of the greatest importance.

In the first place, we should protect ourselves agaiust their increase. This may be done (in a measure) :-

By decomposing all manures in compost, whereby 
many of the seeds contained will be killed by the heat of fermentation.

By hoeing, or otherwise destroying growing weeds before they mature their seeds; and

By keeping the soil in the best ehemical condition.

This last point is one of much importance. It is well known that soils deficient in potash will naturally produce one kind of plants, while soils deficient in phosphoric acid will produce plants of another species, etc. Many soils produce certain weeds which would not grow on them spontaneously if they were fitted for the growth of better plants. It is also believed that those weeds, which naturally grow on the most fertile soils, are the ones most easily destroyed. There are exceptions (of which the Thistle is one), but this is given as a general rule.

By careful attention to the foregoing points, weeds may be kept from increasing, while those already in the soil may be eradicated in varions ways, chiefly by mechanical means, such as hoeing, plowing, etc.

Prof. Mapes used to say, and experience often shows, that six bushels of salt annually sown broadcast over each acre of land, will destroy very many weeds, as well as grubs and worms.

The common hoe is a very imperfect tool for the purpose of removing weeds, as it prepares a better soil for, and replants in a position to grow, nearly as many weeds as it destroys.

The scuffle-hoe (or push-hoe) is much more effective, as, when worked by a man walking backward, 
and retiring as he works, it leaves nearly all of the weeds on the surface of the soil to be killed by the sun. When used in this way, the earth is not trodden on after being hoed-as is the ease when the common hoe is employed. This treading, besides compacting the soil, covers the roots of many weeds, and causes them to grow again.

The scuffle-hoe, however, except in very light soil, will not run so deeply as it is often desirable to loosen it, and must, in such eases, be superseded by the prong-hoe (or potato-hook), which is a capital substitute for the common hoe in nearly all cases.

Much of the labor of weeding usually performed by men, might be more cheaply done by horses. There are various implements for this purpose, some of which have come into very general use.

One of the best of these is the Langdon IIorse Hoe, which is a shovel-shaped plow, to be run one or two inches deep. It has a wing on each side to prevent the earth from falling on to the plants in the rows. At the rear, or upper edge, is a kind of rake or comb, which allows the earth to pass through, while the weeds pass over the comb and fall on the surface of the soil, to be killed by the heat of the sun. It is a simple and cheap tool, and will perform the work of twenty men with hoes. The hand hoe will be necessary only in the rows.

\section{CULTIVATORS.}

The cultivator, which was described in the preeeding chapter, and of which there are various pat- 
terns in use, is excellent for weeding and tor loosening the soil between the rows of corn, etc. The one called the universal cultivator, having its side bars made of iron, eurved so that at whatever distance it is placed the teeth will point straight forward, is a inuch better tool than those of the older patterns, which had the teeth so arranged that when set for wide rows, they pointed toward the clevis. It is difficult to keep such a eultivator in its place, while the "universal" is as difficult to move out of a straight line.

IMPROVED HORSE-HOE.

The improved (or Knox's) horse-hoe, is a combina-

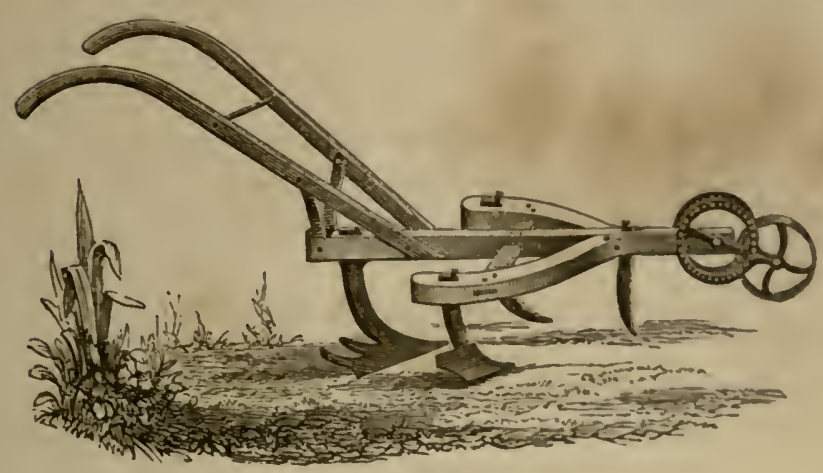

FiG. 7.

tion of the "Langdon" horse-hoe and the cultivator, and is the best implement, for many purposes, that has yet been made.

An excellent tool, called a Muller, is used in Rhode 
Island. It consists of a stick of heavy wood, five or six feet long and about three inches by six inches in size, drawn by fastening one trace to each end, having stilts or handles rising from the upper side, and two rows of sharpened iron teeth six inches long on the under side-the front row of teeth point forward, and the rear row backward. It is a "horse-rake" for the ground, and leaves it as fine as a hand-rake would, while it works it much more deeply.

One of the best cultivators that it is possible to use between rows of corn-or other plants-is a small sub-soil plow of the kind shown on p. 201, drawn by one horse, and running five or six inches deep. It mellows the land deeply and thoroughly.

There is much truth in the following proverbs:

"A garden that is well kept, is kept easily."

"You must eonquer weeds, or weeds will conquer you."

"The best time to kill weeds is before they come up." "

It is almost impossible to give a recapitulation of the matters treated in this section, as it is, itself, but an outline of subjects which might occupy our whole book. The scholar and the farmer should understand every principle which it contains as well as they understand the multiplication table; and their application will be found, in every instance, to produce the best results. 
CLLTTYATION.

The two great rules of mechanical cultivation are-

THOROdGH UNDER-DRANING.

DeEP AND Frequext DISTURBaxce OF THE SOIL. 



\section{SECTIOY FIFTH.}

A NALYSIS. 



\section{SECTION FIFTH.}

\section{A NAL Y IS.}

\section{CHAPTER I.}

Ar the time when this book was tirst written, in 1853 , it was the very general opinion of seientific, and of many practical, men, that it was within the power of the chemist, by separating the different parts of the soil, weighing each, to determine whether the soil were fertile or barren; how long it might continue fertile without the use of manure; what manures were best suited to restoring or preserving its fertility; and what class of plants it was best fitted to produce.

In this belicf, these pages were devoted, very largely, to showing the farmer how he could best regulate his operations in the light of such teachings as soil analysis gives.

As is often the case in the adoption of new discoreries, a further acquaintance with the subject showed 
that, so far as the processes of practical agriculture are concerned, soil analysis is of but little, if any, value. True, the amount of potash, for instance, which is contained in the soil, may be determined with great precision, and it seemed, at first, that this sort of knowledge was enough for practical use; but further research and reasoning have shown that the question of. quantity is of no more consequence than the question of condition. Of the potash in the soil only the $\frac{1}{100}$ or the $\frac{1}{1000}$ part is arailable to the plants of a single year's growth;-why the other 99 , or 999 parts are not available, and how they may be made so, the soil analysis, from which so much was hoped for, does not tell us.

The causes of fertility and barrenness lie beyond the reach of weight and measure, and it is an unfortunate truth that, aside from a very simple indication of the internal character of our soils, the science of chemistry can only help us in studying their character when we follow it through the by-ways of its more subtle reasoning. Much of what is known of the manner in which the soil gives nutriment to the plant has been learned from the bringing together of the results of many experiments,-studying them by the light of what chemistry has positively taught. This knowledge is of great value, and is sufficient to form the foundation of a really scientific agrieulture; but there is no doubt that much more is yet to be learned, and that we are still very far from knowing all that we must know of the use of manures, the functions of the soil, and the growth of plants. 
While waiting for its further instruction, let us make the best possible use of what chemistry now teaches with certainty, in the analysis of the ashes of plants, and of manures.

Practice and science have combined to show us how all soils may be raised to a high, possibly to the highest, state of fertility, and a knowledge of the composition of crops and manures shows how we may best maintain its good condition.

The one safe rule for all farmers to adopt is tho following:-

ALwAYS RETURN IN THE EARTHY CONSTTUE EITS OF MANURE TIIE FULL EQUTVALENT OF THE EARTIY CO\&STITUENTS OF TIIE CROP.

This will prevent the soil from deteriorating, and we may safely trust to the process of cultivation, and to the action of atmospheric influences, to make it yearly better, by developing fresh supplies of its ashforming parts. 


\section{CHAPTER II.}

T A B LES OF A N A I Y S I B.

\section{ANALYSES OF THE ASHES OF CROPS.}

No. I.

\begin{tabular}{|c|c|c|c|c|}
\hline & Wheat. & $\begin{array}{l}\text { Wheat } \\
\text { Straw. }\end{array}$ & Rye. & $\begin{array}{c}\text { Rye } \\
\text { Straw. }\end{array}$ \\
\hline Ashes in 1000 dry parts...... & 20 & 60 & 24 & 40 \\
\hline 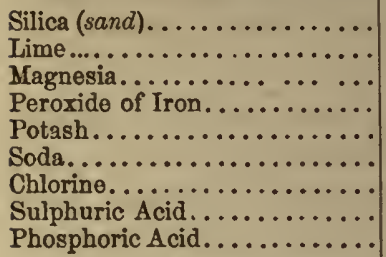 & $\begin{array}{r}16 \\
28 \\
120 \\
7 \\
237 \\
91 \\
3 \\
3 \\
498\end{array}$ & $\begin{array}{r}654 \\
67 \\
33 \\
13 \\
124 \\
2 \\
11 \\
58 \\
31\end{array}$ & $\begin{array}{r}5 \\
50 \\
104 \\
14 \\
221 \\
116 \\
10 \\
19\end{array}$ & $\begin{array}{r}645 \\
91 \\
24 \\
14 \\
174 \\
17 \\
3 \\
5 \\
8 \\
38\end{array}$ \\
\hline
\end{tabular}

No. II.

\begin{tabular}{|c|c|c|c|c|}
\hline & Corn. & $\begin{array}{c}\text { Corn } \\
\text { Stalks. }\end{array}$ & Barley. & $\begin{array}{l}\text { Barley } \\
\text { Straw. }\end{array}$ \\
\hline Ashes in 1000 dry parts...... & 15 & 44 & 28 & 61 \\
\hline Silica $(\operatorname{san} d) .$. & 15 & 270 & 271 & 706 \\
\hline Lime................ & 15 & 86 & 26 & 95 \\
\hline Magnesia ....... & 162 & 66 & 75 & 32 \\
\hline Peruxide of Iron............. & 3 & $8^{7}$ & 15 & 7 \\
\hline Oxide of Manganese........... & & & & 1 \\
\hline Potash $\ldots \ldots \ldots \ldots \ldots \ldots$ & 261 & 96 & 136 & 62 \\
\hline Soda.................... & 63 & 277 & 81 & 6 \\
\hline Chlorine............... & 2 & 20 & 1 & 10 \\
\hline Sulphuric Acid........... & 23 & 5 & 1 & 16 \\
\hline Phosphoric Acid......... & 449 & 171 & 389 & 31 \\
\hline
\end{tabular}


No. III.

\begin{tabular}{|c|c|c|c|c|}
\hline & Oats. & $\begin{array}{l}\text { Ont } \\
\text { Straw. }\end{array}$ & $\begin{array}{l}\text { Buck } \\
\text { Whest. }\end{array}$ & $\begin{array}{c}\text { Po- } \\
\text { tatoes. }\end{array}$ \\
\hline Ashes in 1000 dry parts........ & 20 & 51 & 21 & 90 \\
\hline 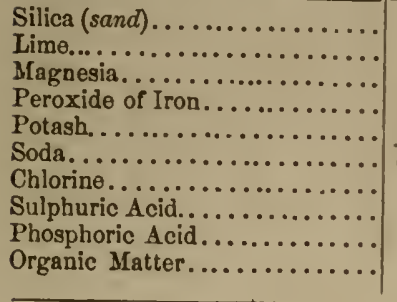 & $\begin{array}{r}7 \\
60 \\
99 \\
4 \\
262 \\
3 \\
104 \\
438\end{array}$ & $\begin{array}{r}484 \\
81 \\
38 \\
18 \\
191 \\
97 \\
32 \\
33 \\
27\end{array}$ & $\begin{array}{r}7 \\
67 \\
104 \\
11 \\
87 \\
201 \\
\\
22 \\
500\end{array}$ & \begin{tabular}{|c}
42 \\
21 \\
53 \\
5 \\
557 \\
19 \\
43 \\
137 \\
126 \\
730 \\
Water.
\end{tabular} \\
\hline
\end{tabular}

No. IV.

\begin{tabular}{|c|c|c|c|c|}
\hline & Peas. & Beans. & Turnips. & $\begin{array}{l}\text { Turnlp } \\
\text { Tops. }\end{array}$ \\
\hline Ashes in 1000 dry parts....... & 25 & 27 & 76 & 170 \\
\hline Silica $($ sand)... & 5 & 12 & 71 & 8 \\
\hline Lime.......... & 53 & 58 & 128 & 233 \\
\hline Magnesia....... & 85 & 80 & 43 & 81 \\
\hline Peroxide of Iron........ & 10 & 6 & 9 & 8 \\
\hline Potash............... & 361 & 336 & 898 & 296 \\
\hline 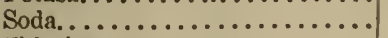 & 91 & 106 & 108 & 54 \\
\hline Chlorine..... & 23 & 7 & 37 & 160 \\
\hline Sulphuric Acid............. & 44 & 10 & 131 & 125 \\
\hline Phosphoric Acid............ & 383 & 378 & 67 & 93 \\
\hline Organic Matter.............. & & & $8 \pi 0$ Water. & \\
\hline
\end{tabular}


No. V.

\begin{tabular}{|c|c|c|c|c|}
\hline & Flax. & Linseer. & $\begin{array}{l}\text { Meadow } \\
\text { Hay. }\end{array}$ & $\mid \begin{array}{l}\text { Red } \\
\text { Clover. }\end{array}$ \\
\hline Ashes in 1000 dry parts...... & 50 & 46 & 60 & 75 \\
\hline $\begin{array}{l}\text { Silica }(\text { sand }) \ldots \ldots \ldots \ldots \ldots \\
\text { Alumina }(\text { clay }) \ldots \ldots \ldots \ldots\end{array}$ & $\begin{array}{l}257 \\
37 ?\end{array}$ & 75 & 344 & 48 \\
\hline Lime............ & 148 & 83 & 196 & 371 \\
\hline Magnesia............. & 44 & 146 & 78 & 46 \\
\hline Peroxide of Iron............. & $36 ?$ & 9 & 7 & 2 \\
\hline Potash . . . . . . . . . . & 117 & 240 & 236 & 267 \\
\hline Soda..................... & 118 & 45 & 19 & 71 \\
\hline Chlorine................. & 29 & 2 & 28 & 48 \\
\hline Sulphuric Acid........ & 32 & 23 & 29 & 60 \\
\hline Pbosphoric Acid........ & 130 & 365 & 58 & 88 \\
\hline
\end{tabular}

No. VI.

Amount of Inorganic Matter removed from the soil by ten bushels of grains, etc., and by the straw, etc., required in their production - - -estimated in pounds:

\begin{tabular}{|c|c|c|c|c|}
\hline . & Wheat. & $\begin{array}{l}1200 \text { lbs. } \\
\text { Wheat } \\
\text { Straw. }\end{array}$ & Rye. & $\begin{array}{c}1620 \text { lbs. } \\
\text { Rye } \\
\text { Straw. }\end{array}$ \\
\hline 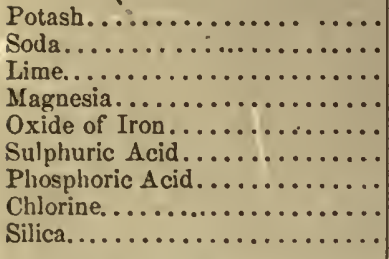 & $\begin{array}{r}2.86 \\
1.04 \\
.34 \\
1.46 \\
.08 \\
.03 \\
6.01 \\
.14\end{array}$ & $\begin{array}{r}8.97 \\
.12 \\
4.84 \\
2.76 \\
.94 \\
4.20 \\
2.22 \\
.79 \\
47.16\end{array}$ & $\begin{array}{r}2.51 \\
1.33 \\
.56 \\
1.18 \\
.15 \\
.11 \\
5.64 \\
.05\end{array}$ & $\begin{array}{r}11.34 \\
.20 \\
5.91 \\
1.58 \\
.88 \\
.05 \\
2.49 \\
.30 \\
42.25\end{array}$ \\
\hline Pounds carried off............. & 12 & 72 & $11 \frac{1}{2}$ & 66 \\
\hline
\end{tabular}


ANALYSIS.

No. VII

\begin{tabular}{|c|c|c|c|c|}
\hline & Corn. & $\begin{array}{c}16: 20 \text { lbs. } \\
\text { Corn } \\
\text { Stalks. }\end{array}$ & Cats. & $\begin{array}{l}\text { oring Itbs. } \\
\text { Oas } \\
\text { Straw. }\end{array}$ \\
\hline $\begin{array}{l}\text { Potash } \ldots \ldots \ldots \ldots \ldots \ldots \ldots \ldots \\
\text { Soda } \ldots \ldots \ldots \ldots \ldots \ldots \ldots\end{array}$ & 2.78 & $\begin{array}{r}6.84 \\
19.83\end{array}$ & 1.63 & 1208 \\
\hline Lime.... & .12 & 6.02 & .39 & 3.3. \\
\hline Magnesia.... & 1.52 & 4.74 & .64 & 1.59 \\
\hline $\begin{array}{l}\text { Oxide of Iron ... } \\
\text { Sulphuric Acid }\end{array}$ & & .57 & .02 & .78 \\
\hline Phosphoric Acid. & 4.52 & $\begin{array}{r}.36 \\
12.15\end{array}$ & 2.80 & $\begin{array}{l}1.41 \\
1.117\end{array}$ \\
\hline Chlorine ......... & & 1.33 & .02 & 1.36 \\
\hline Silica & .06 & 19.16 & .18 & 20.32 \\
\hline Pounds carried off... & 9 & 71 & $6 \frac{1}{t}$ & 42 \\
\hline
\end{tabular}

No. VIII.

\begin{tabular}{|c|c|c|c|c|}
\hline & $\begin{array}{l}\text { Buck } \\
\text { Wheat. }\end{array}$ & Barloy. & $\begin{array}{l}\text { Gon bols. } \\
\text { Barley. } \\
\text { Strow. }\end{array}$ & $\begin{array}{l}2000) 1 b e . \\
\text { Fax. }\end{array}$ \\
\hline Potash. & 1.01 & 1.90 & 2.57 & 11.78 \\
\hline Soda & 2.13 & 1.18 & .23 & 11.82 \\
\hline Lime..... & .78 & .96 & 3.88 & 11.55 \\
\hline Magnesia. & 1.20 & 1.00 & 1.81 & 9.33 \\
\hline Oxide of Iron & .14 & .20 & .90 & 7.32 \\
\hline Sulphuric Acid............. & .25 & .01 & .66 & 3.19 \\
\hline I'hosphoric Acid.............. & 5.40 & 5.35 & 1.25 & 13.05 \\
\hline Chlorine.... & & .01 & .40 & 2.90 \\
\hline Silica..... & .09 & 3.90 & 28.80 & 25.71 \\
\hline Pounds carried off. & 11 & 14 & 40 & 100 \\
\hline
\end{tabular}


No. IX.

\begin{tabular}{|c|c|c|c|c|}
\hline & Beans. & $\begin{array}{c}1120 \mathrm{lbs} . \\
\text { Bean. } \\
\text { straw. }\end{array}$ & $\begin{array}{l}\text { Field } \\
\text { Pess. }\end{array}$ & $\begin{array}{c}1866 \mathrm{lbs} \\
\text { Pea } \\
\text { Straw. }\end{array}$ \\
\hline Potash..... & & 36.28 & $\begin{array}{l}5.90 \\
1.40\end{array}$ & 3.78 \\
\hline -............ & $\begin{array}{r}1.83 \\
98.98\end{array}$ & $\begin{array}{r}1.09 \\
13.60\end{array}$ & $\begin{array}{r}1.40 \\
.81\end{array}$ & \\
\hline$\because \cdots$ & $\begin{array}{r}0.00 \\
28\end{array}$ & $\begin{array}{r}13.60 \\
4.55\end{array}$ & 1.30 & $\begin{array}{r}43.93 \\
5.50\end{array}$ \\
\hline Oxic & .1 & $\begin{array}{r}.00 \\
.20\end{array}$ & .15 & $\begin{array}{l}0.00 \\
1.40\end{array}$ \\
\hline Sulphuric Acid. & .1 & .6 & .64 & 5.43 \\
\hline Phosphoric Acid.. & 7.80 & 5.00 & 5.50 & 3.86 \\
\hline Chlorine & .13 & 1.74 & .23 & .08 \\
\hline Silica. & .18 & 4.90 & .7 & 16.02 \\
\hline Pounds carried o & 17 & 68 & 16 & 80 \\
\hline
\end{tabular}

No. $\mathrm{X}$.

\begin{tabular}{|c|c|c|c|c|}
\hline & $\begin{array}{l}1 \text { Ton } \\
\text { Turnips. }\end{array}$ & $\begin{array}{l}635 \text { lbs. } \\
\text { Turnip } \\
\text { Tops. }\end{array}$ & $\begin{array}{l}1 \text { Ton } \\
\text { Potatoes. }\end{array}$ & $\begin{array}{l}2000 \mathrm{lbs} . \\
\text { Red } \\
\text { Clover. }\end{array}$ \\
\hline Potash. & 7.14 & 4.34 & 27.82 & 31.41 \\
\hline Soda... & .86 & .84 & .93 & 8.34 \\
\hline Lime. . & 2.31 & 3.61 & 1.03 & 43.77 \\
\hline Magnesia. & .91 & .48 & 2.63 & 6.25 \\
\hline Oxide of Iron & .2 & .33 & .26 & .23 \\
\hline Sulphuric Acid. & 2.30 & 1.81 & 6.81 & 7.05 \\
\hline Phosplioric Acid... & 1.29 & 1.31 & 6.25 & 10.28 \\
\hline Chlorine.......... & .61 & 2.35 & 2.13 & 5.86 \\
\hline Silica ............ & 1.36 & .13 & 2.14 & 5.81 \\
\hline Pounds carried off...... & 17 & 15 & 50 & 118 \\
\hline
\end{tabular}


No. XI.

\begin{tabular}{|c|c|c|}
\hline & $\begin{array}{l}\text { 9000 lbs. } \\
\text { Mealow } \\
\text { IIay. }\end{array}$ & $\begin{array}{l}\text { 2000 lbs. } \\
\text { Cabbage. } \\
\text { W ster o-i0 }\end{array}$ \\
\hline & 18.11 & 5.25 \\
\hline$\ldots \ldots \ldots \ldots \ldots \ldots \ldots \ldots \ldots$ & 1.35 & 9.20 \\
\hline 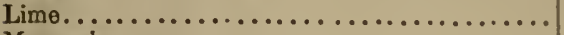 & 22.95 & 9.45 \\
\hline 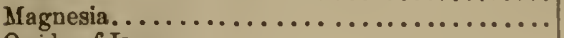 & 6.76 & 2.70 \\
\hline Oxide of Iron..$\ldots \ldots \ldots \ldots \ldots \ldots \ldots \ldots \ldots$ & 1.69 & .25 \\
\hline Sulphuric Acid. ........... & 2.70 & 9.60 \\
\hline Phosphoric Acid................... & 6.97 & 5.60 \\
\hline Chlorine......................... & 2.89 & 2.60 \\
\hline Silica............................ & 87.89 & .85 \\
\hline .9 & $: 00$ & 45 \\
\hline
\end{tabular}

No. XII.

Composition of Ashes, leached and unleached, showing their manurial value:

\begin{tabular}{|c|c|c|c|c|}
\hline 10 & 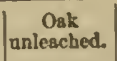 & $\begin{array}{c}\text { Oak } \\
\text { leached. }\end{array}$ & $\begin{array}{c}\text { Beech } \\
\text { onlesched. }\end{array}$ & $\begin{array}{c}\text { Peech } \\
\text { leeched. }\end{array}$ \\
\hline 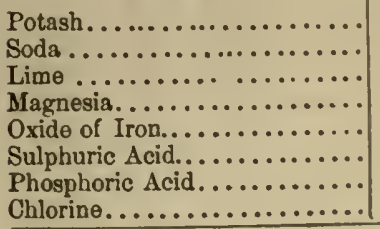 & $\begin{array}{r}84 \\
56 \\
750 \\
45 \\
6 \\
12 \\
35\end{array}$ & $\begin{array}{r}548 \\
6\end{array}$ & $\begin{array}{r}158 \\
29 \\
634 \\
113 \\
8 \\
14 \\
31 \\
2 \\
\end{array}$ & $\begin{array}{r}426 \\
70 \\
15\end{array}$ \\
\hline
\end{tabular}


No. XIII.

\begin{tabular}{|c|c|c|c|}
\hline & $\begin{array}{c}\text { Birch } \\
\text { leached. }\end{array}$ & $\left|\begin{array}{c}\text { Seaweed } \\
\text { unieasched. }\end{array}\right|$ & $\begin{array}{l}\text { Bitumin- } \\
\text { ous Coal } \\
\text { unleached. }\end{array}$ \\
\hline Potash . & & 180 & 2 \\
\hline $\begin{array}{l}\text { Soda........ } \\
\text { Lime........ }\end{array}$ & 522 & 94 & 21 \\
\hline Magnesia.. & 30 & 99 & 2 \\
\hline Oxide of Iron & 5 & 3 & 40 \\
\hline Sulphuric Acid. & & 248 & 9 \\
\hline Phosphoric Acid.................. & 43 & 52 & 2 \\
\hline Chlorine $\ldots \ldots \ldots \ldots \ldots \ldots \ldots \ldots \ldots$ & & 98 & 1 \\
\hline
\end{tabular}

No. XIV.

T O B A C O.

Analysis of the ash of the PLANT [Will \& Fresenius]-

Potash.

Soda

Magnesia.

11.07

Lime.

48.68

Phosphioric Acid.

Sulphuric Acid.

Oxide of Iron.

2.99

Chlorido of Sodium.

Loss. .

6.95

Analysis of the ash of the ROOT [Berthier] -

Soluble Matter ......................... 12.3

Insoluble Matter............................. 87.7

The Soluble parts consist of uearly-

Carbonic Acid........................... 10.0

Sulphuric Acid .............................. 10.3

Muriatic Acid (Chlorine, \&c.) ... ............... 18.26

Potash and Soda.............................. 61.44 


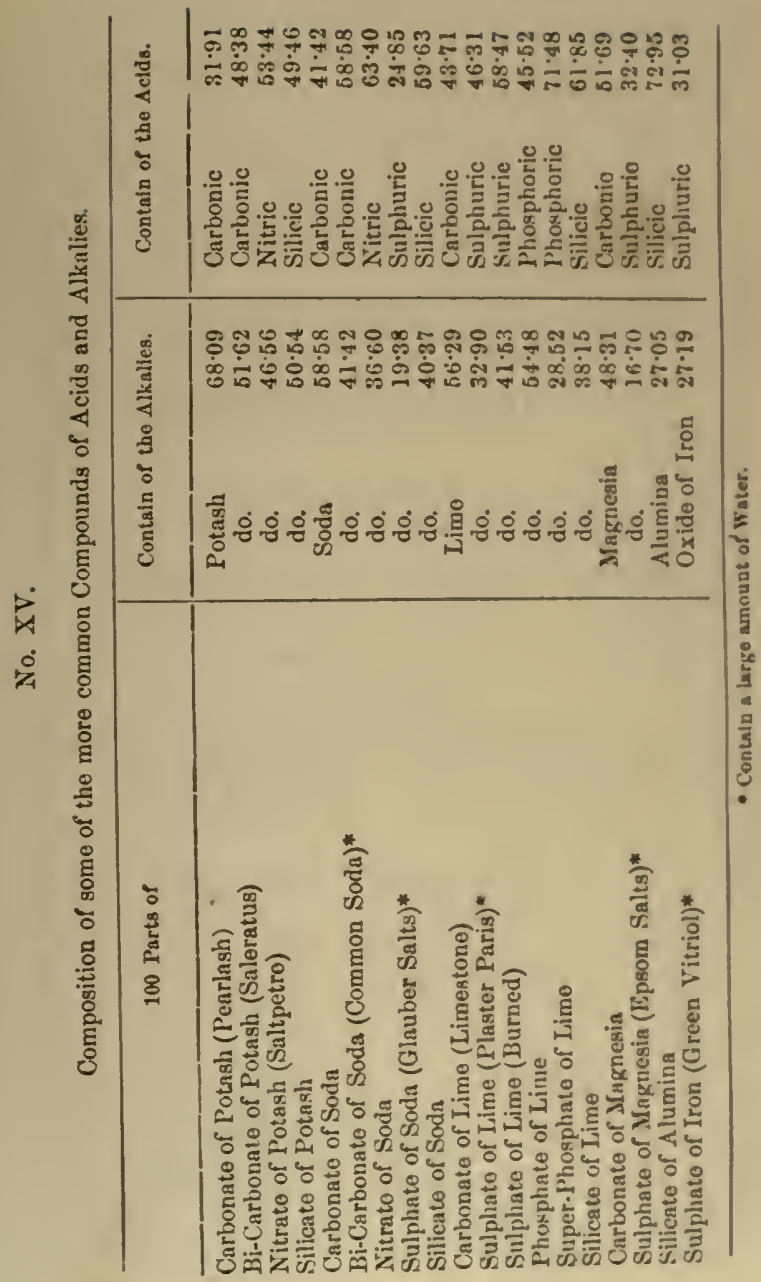




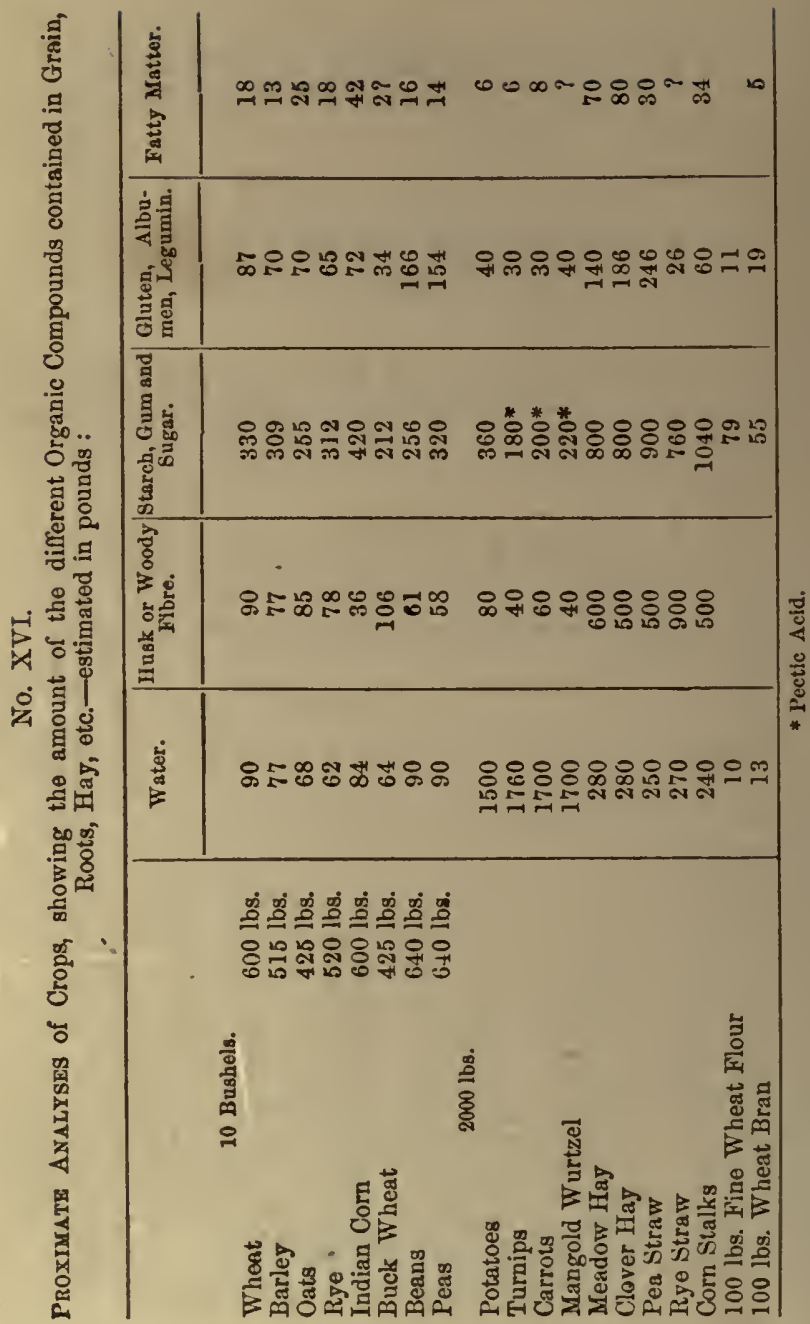


No. XVII.

Amount of Ash left after burning 1000 lbs. of various plante, ordina-

Wheat

Barley

Oats

Rye

Indian Corn

Pea

Bean

Meadow Hay

Clover

Rye Grass "

Potato

Turnip

Carrot
20

30

40

20

15

30

30

50 to 100

90

95

8 to 15

5 to 8

15 to 20 its straw $\quad 50$

50

6)

41)

50

50

No. XVIII.

MANURES.

Solid Dung-

MORSE YAYURE.

Combustible Matter.................... 19.68

Ash................................. 3.07

Water............................ 77.25

Composition of the Ash- $\quad \overline{10.000}$

Silica.................................. 62.40

Potash.................................. 11.s0

Soda.................................... 1.88

Oxide of Iron........................... 1.17

Lime.................................. 4.63

Magnesia............................. 3.84

Oxide of Manganese...................... 2.13

Phosphoric Acid......................... 10.49

Sulphuric Acid........................ 1.89

Chlorine.............................. 0.08

Loss................................. 0.14 
No. XIX.

Solid (Ash) -

XIG IT SOIL.

Earthy Phosphates, and a trace of Sulphate of Lime..... 100

Sulphate of Soda and Potash, and Phosphate of Soda.... 8

Carbonate of Soda........................ 8

Silica............................. 16

Charcoal and Loss..................... 18

150

Urine-

Urea*....................... 30.10

Uric Acid....................... $1 . n 0$

Sal Ammoniac*..................... 1.50

Lactic Acid, etc. .................. 17.14

Mucus..................................

Sulphate of Potash................ 3.71

Sulphate of Soda................. 3.16

Phosphate of Ammonia ${ }^{*} . \ldots \ldots \ldots \ldots \ldots \ldots . \quad 1.65$

Earthy Phosphates................. $\quad 3.94$

Salt (Chloride of Sodium) :........... 4.45

Silica........................ 0.03

Water.......................... $\quad 933.00$

* Supply Ammonia.

1000.00

$\therefore$

No. $\mathrm{XX}$.

Solid (Ash) -

COW MAN DRE.

Phosphates.......................... 20.9

Peroxide of Iron................... 8.8

Lime.......................... 1.5

Sulphate of Lime (Plaster,................ 3.1

Chloride of Potassium................... trace

Silica............................. 63.7

Loss........................... 2.0 


\section{ANALYSIS.}

No. XXI.

COMPARATIVE VALUE OF THE URINE OF DIFFERENT ASTMALS

\begin{tabular}{|c|c|c|c|}
\hline \multicolumn{4}{|c|}{ Solid Matter. } \\
\hline & Organic. & Inorganic. & Total. \\
\hline & 23.4 & 7.6 & 81 \\
\hline Horse. & 27. & 33. & 60 \\
\hline Cow.. & 50. & 20. & 70 \\
\hline Pig... & 56. & 18. & $7 t$ \\
\hline Sheep. & 28. & 12. & 40 \\
\hline
\end{tabular}

No. XXII.

GUA ×.

Water.................................. 6.40

Ammonia................................... 2.71

Uric Acid.................................. 3470

Oxalic Acid, tetc..................................... 26.79

Fixed Alkaliue Salts.

Sulphate of Soda......................... 2.94

Phosphate of soda.......................... $\quad .48$

Chlorido of Sodium (salt)..................... $\quad .86$

Eartlyy Salts.

Carbonate of Lime......................... 1.38

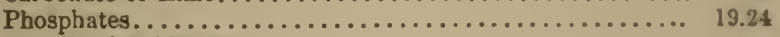

Foreiga Matter.

Silicious grit and sand.................... 4.53

100.00

Composition of Fresh Farm-yard Mannre, (composed of Horse, Pig, and Cow Dung, about 14 days nld). Analysis made Nov. 3d, 1854, by Dr. Augustus Voelcker, Professor of Chemistry in the Royal $\triangle g^{-}$ ricultural College, Cirencester, England:

Water.

Soluble Organic Matter.

* Soluble Inorganic Matter (Ash) -

Soluble Silica (silicic acid).............. . .237

Phosphate of Lime...................... .299

Lime............................. .066

Magnesia............................ .011

Potash ............................573

- Containing Nitrogen............... .149

Equal to Ammonia.............. $\quad .181$ 
Chloride of Sodium.................... .030

Carbonic Acid and loss................ $\quad .218$

*Insoluble Organic Matter.................. 25.76

Insoluble Inorganic Matter (Ash)-

Soluble Silica $\{$ silicic acid $\} \ldots \ldots \ldots \ldots \ldots . .967$

Insoluble Silica $\{$ silicic acid $\} \ldots \ldots \ldots \ldots \ldots \ldots \ldots \ldots \ldots \ldots .561$

Oxide of Iron, Alumina, with Phosphates...... $\quad .596$

(Containing Phosphoric Acid, .178)

(Equal to bone earth,

$.386)$

Lime.......................... 1.120

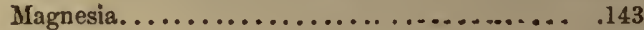

Potash............................. .099

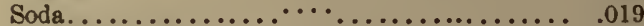

Sulphuric Acid....................... .061

Carbonic Acid and loss............... $\quad .484$

100.00

According to this analysis one ton (2,000 lbs.) Farm-yard Manure contains-

Soluble Silica (silicic acid)

Ammonia (actual or potential)

24 lbs.

Phosphate of Lime.

$\operatorname{Lim} \theta$ $137_{0} "$

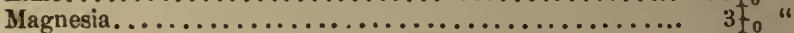

Potash.......................................... $13 \frac{1}{2}$ "

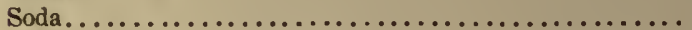

Common Salt

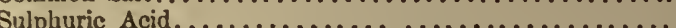

Water.........................................

Woody Fibre, etc ................................ 579 "

Of course no two samples of Farm-yard Manure are exactly of the same composition. That analyzed by Dr. Voelcker was selected with much care, as representing a fair average.

\section{GREEN SAND SMARL (OF NEW JERSEY).}

Protoxide of Iron ......................... 15.5

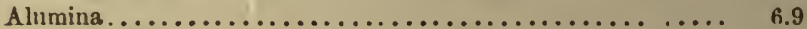

Lime.................................. 5.3

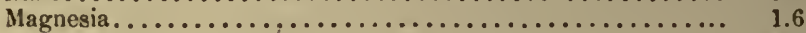

Potash.................................... 4.8

* Containing Nitrogen................ .494

Equal to Ammonia.............. - .599

The whole Manure contains Ammonia in a free state....... .034 " " " " $"$ in the form of salts...." .088 
Soluble Silica........................... 32.4

Insoluble Silica and Sand..................... 19.8

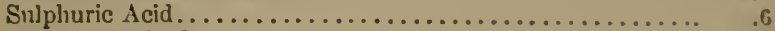

Phosphoric Acid.............................. 1.3

Water.................................... 8.0

Carbonic Acid, etc............................. 3.3

100.0

This is an average of three analyses copied from Prof. Geo. 11. Cook s report of the Geology of New Jersey. According to this estimato one ton (2000 lbs.) of Green Sand Marl contains-

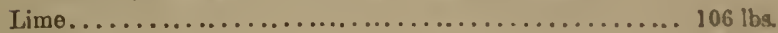

Magnesia.............................. 32 "

Potash ................................ 96 "

Soluble Silicic Acid...........................649 "

Sulphuric Acid......................... 12 "

Phosplioric Acid ............................ 26 "

(Equal to Phosphate of Lime $56 \frac{1}{1}$ lbs.)

For the analysis of fertile and barren soils, see page 63. 

THE PRACTICAL FARMER. 



\section{THE PRACTICAL FARMER.}

Wro is the practical farmer? Let us look at two pictures and decide.

Here is a furm of 100 acres in ordinary condition. It is owned and tilled by a hard-working man, who, in the busy season, employs one or two assistants. The farm is free from debt, but it does not produce an abundant incone; therefore, its owner cannot afford to purchase the best implements or make other needed improrements; besides, he don't believe in such things. His father was a good solicl farmer; so was his grandfather; and so is he, $01^{\circ}$ he thinks he is. He is satisfied that "the good oll way" is best, and he sticks to it. He works from morning till night; from spring till fall. In the winter he rests, as much as his lessened duties will allow. During this time, he reads little, or nothing. Least of all does he read about farming. He don't want to learn how to dig potatoes out of a book. Book farming is nonsense. Many other similar ideas keep him from agricultural reading. His honse is comfortable, and his barns are quite as good as his 
neighbors', while his farm gives him a living. It is true that his soil does not produce as much as it did ten years ago; but prices are better, and he is satisfied.

Let us look at his premises, and see how his affairs are managed. First, examine the land. Well, it is good fair land. Some of it is a little springy, but it is not to be ealled wet. When first laid down, it will produce a ton and a half of hay to the acre-it used to prodnce two tous. There are some stones on the land, but not enough, in his estimation, to do harm. The plowed fields are pretty good; they will prodnce 35 bushels of eorn, 13 bushels of wheat, or 30 bushels of oats per acre, when the season is not dry. His father used to get more; but, somehow, the weather is not so favorable as it was in old times. He has thought of raising root crops, but they take more labor than he ean afford to hire. Over in the back part of the land there is a muck-hole, which is the only piece of worthless land on the whole farm.

Now, let us look at the barns and barn-yards. The stables are pretty good. There are some wide eracks in the siding, but they help to ventilate, and make it healthier for the cattle. The manure is thrown out of the back windows, and is left in piles under the eaves of the barn. The rain and sun make it nicer to handle. The cattle have to go some distance for water; and this gives them exercise. All of the eattle are not kept in the stable; the fattening stock are kept in the various fields, where hay is fed out to them from the stack. The barn-yard is 
often occupied by eattle, and is covered with their manure, which lies there until it is carted on to the land. In the shed are the tools of the farm, consinting of carts, plows-not deep plows: this farmer thinks it best to have roots near the surface of the soil where they ean have the benctit of the sun's heat, -a harrow, hoes, rakes, ete. These tools are all in good order; and, unlike those of his less prudent neighbor, they are protected fiom the weather.

The crops are cultivated with the plow and hoe, as they have been since the land was cleared, and as they alwars will be mitil this man dies.

Here is the 'practical farmer' of the present day. Hard working, out of debt, and economical, - of dullars and cents, if not of soil and manures. Hle is a better furmer than two-thirds of the three million farmers in the country. He is one of the best farmers in his town-there are but few better in the county, not many in the State. He represents the better average class of his profession.

With all this, he is, in matters relating to his business, an unreading, unthinking man. IIe knows nothing of the first principles of farming, and is successful by the indulgence of nature, not because he understands her, and is able to make the most of her assistance.

This is an unpleasant fact, but it is one which eannot be denied. We do not say this to disparage the farmer, but to arouse lim to a realization of his position, and of his power to improve it.

But let us see where he is wrong. 
He is wrong in thinking that his land does not need draining. He is wrong in being satisfied with one and a half tons of hay to the acre when he might easily get two and a half. He is wrong in not removing as far as possible every stone that can interfere with the deep and thorough enltivation of his soil. He is wrong in reaping less than his father did, when he should get more. He is wrong in ascribing to the weather, and similar canses, what is due to the actual imporerishment of his soil. He is wrong in not raising turnips, carrots, and other roots, which his winter stock so much need, when they might be raised at a cost of less than one-third of their value as food. He is wrong in considering worthless a deposit of muck, which is a mine of wealth if properly employed. He is wrong in ventilating his stables at the cost of heat. He is wrong in his treatment of his manures, for he loses more than one half of their valne from evaporation, fermentation, and leaching. $\mathrm{He}$ is wrong in not having water at hand for his cattle-their exercise detracts from their aceumulation of fat and the economy of their heat, and it exposes them to cold. He is wrong in not protecting his fattening stock from the cold of winter; for, under cxposure to cold, the food, which would otherwise be used in the formation of $f a t$, goes to the production of the animal heat necessary to counteract the chilling influence of the weather, p. 44. He is wrong in allowing his manure to lie unprotected in the barn-yard. He is wrong in not adding to his tools the deep surface plow, the 
sub-soil plow, the enltivator, and many other implements of improved construction. He is wrong in cultivating with the plow and hoc, those crops which eonld be better or more cheaply managed with the cultirator or horse-hoe. He is wrong in many things unore, as we shall see if we examine all of his yearly routine of work. IIe is right in a few things; and but a few, as lie himself would admit, had he that knowledge of his business which he conld ohtain in the leisure hours of a single winter. Still he thinks himself a practical farmer. In twenty years, we shall have fewer such, for our young men lave the mental eapacity and mental enerry necessary to raise them to the higliest point of practical education, and to that point they are gradually but surely rising. We have far fewer now than twenty years ano.

Let us now place this same farm in the hands of an elucated and understanding cultivator; and at the end of five years, look at it again :

He has sold one half of it, and enltivates but fitty acres. The money for which the other fitty were sold has been nsed in the improvement of the farm. The land has all been under-drained, and shows the many inprovements consequent on such treatment. The stones and small rocks liave been remored, learing the surface of the soil smooth, and allowing the use of the sub-soil plow, which, with the under-drains, has more than doubled the productive power of the farm. Sufticient labor is employed to cultivate with improred tools, extensive root crops, and they invariably gire a large yield. The grass land produces a 
yearly average of $2 \frac{1}{2}$ tons of hay per acre. From 80 to 100 bushels of corn, 30 bushels of wheat, and 45 bushels of oats are the arerage of the crops reaped. The soil has been put in the best possible condition, while it is regularly supplied with manures containing everything taken away in the abundant crops. The principle that all earthy matters sold away must be bought back again, is never lost sight of in the regulation of crops and the application of manures. The roorthless muck-bed was retained, and is made worth a dollar a load to the compost-heap, especially as the land reqnires an increase of organic matter. $\Lambda$ new barn has been built large enough to store all of the hay produced on the farm. It has stables, which are tight and warm, and are well ventilated above the eattle. The stock being thus protected from the loss of their heat, give more milk, and make more fat on a less amount of food than they did under the old system. Water is near at hand, and the animals are not obliged to orer-exereise. The manure is carefully composted, either under a shed constructed for the purpose with a tank and pump, or is thrown into the cellar below, where the hogs mix it with a large amount of muck, which lias been carted in after being thoronghly decomposed by the lime and salt mixture.

They are thus protected against all loss, and are prepared for the immediate use of crops. No manures are allowed to lie in the barn-yard, but they are all early removed to the compost heap, where they are preserved by being mixed with carbona- 
ceous matter. In the tool shed, we find deep surface-plows, sub-soil plows, enltivators, horscheres, seed-drills, and many other valualsle implements.

This farmer takes one or more agricultural papers, firom which he learns new methods of cultivation, while his knowledge of the reasons of varions agricultural effects enables him to discard the injudicious suggestions of mere book furmers and uneducated dreamers.

IIere are two specimen firmers. Neitlier description is orer-drawn. The first is much more careful in his operations than the majority of our rural population. The second is no better than many who may be found in America.

We appeal to the common sense of the reader of this work to know which of the two is the practical farmer-let him imitate either, as lis judgment shall dictate. 



\section{EXPLANA'TION OF TERMS.}

Arsorib-to soak up a liquid or gas, or to take substances from air or from watery solutions.

AIssTRACT-to take from.

$\Lambda$ CrD-sour ; a sour substance.

AGRICULTURE-the art of cultivating the soil.

ALKALI - the direct opposite of an acid, with which it has a tendency to unite.

ALUMIXA - the base of clay.

AxALYsis - separating into its primary parts any complound substance.

Carmoxate-a compond, consisting of carbonic acid and an alkali.

Catstic-burning.

CrILOIDE-a compound containing chlorine.

CLEVIS-that part of a plow by which the drawing power is attached.

DEcourose-to separate the constituents of a body from their combinations, forming simple substances into new coinpounds.

DIOEsTrox-the decomposition of food in the stomach and intestines of animals (agricultural).

DEW-deposit of the insensible vapor of the atmosphere on colld surfaces.

EXCREMExT-the matter given ont by the organs of plants and animals, being those parts of their food which they are unsble to assimilate.

Fensextatiox-a kind of decomposition

GAS-air-aeriform matter.

INGREDIENT-component part. 
Irongurrc-wineral, or earhy. not ongmired hy snimsl or regetable life.

MorLDEuARD-that pert of the suriace-plow which tares the sad

Molcurg-oorering the soll with litter: leares, or other refuse matte: See $\mathrm{p} 212$.

SETTRuLrs-io orenome the characteristic properies or effects ce.

ORGAIIC MATTER-iba: kiod of matter which passesses or has possessed an organised (or living) form.

Oxtoz - compound of oxyeen with a metsil.

PzOSPHATE- compocend of phosphoric scil with an alksli.

PtSGENT-prickin:-

PLTREPACTIOX-20:ting.

SATCRATE-io ffll the pores of ant substamoe, as a sponge with wates, or ckstcoal with smmonia.

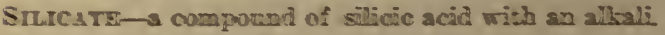

SOLCRIE-cspable of being dissolred.

Soltrios-a liquid containing another substance dissolved in it. SATURATED SOLTTIOx-one which coniains as much of the foreign subsiance ss it is carable of holüing. SPoxGroldis- the ahsorbent ends of roots

STLPHATE-s compoed of schphuric seid with an alisali TAFOR-( 
$-$

$=$

-

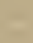



$-$ 


\section{S}

495

W27
THE LIBRARY

UNIVERSITY OF CALIFORNIA

Santa Barbara

THIS BOOK IS DUE ON THE LAST DATE STAMPED BELOW. 


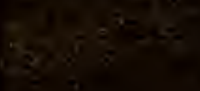

